\title{
DOES MEASURED SCHOOL QUALITY \\ REALLY MATTER? AN EXAMINATION OF \\ THE EARNINGS-QUALITY RELATIONSHIP
}

\author{
James Heckman \\ Anne Layne-Farrar \\ Petra Todd
}

Working Paper 5274

\section{NATIONAL BUREAU OF ECONOMIC RESEARCH 1050 Massachusetts Avenue \\ Cambridge, MA 02138 \\ September 1995}

We are especially grateful to Derek Neal for his very helpful comments. Valuable insights were also provided by Gary Burtless, Casey Mulligan, Bo Honore, Jose Scheinkman, and Bob Willis. We thank Jonathan Bone for assistance in collecting the schooling quality data. This research was supported by the American Bar Foundation. An earlier version was supported by NSF-SBR91-11145, NSF-FES-9224079 and the Mellon Foundation. This paper was presented at the Brookings Institution, June 1994. This paper is part of NBER's research program in Labor Studies. Any opinions expressed are those of the authors and not those of the National Bureau of Economic Research.

(C) 1995 by James Heckman, Anne Layne-Farrar and Petra Todd. All rights reserved. Short sections of text, not to exceed two paragraphs, may be quoted without explicit permission provided that full credit, including $\odot$ notice, is given to the source. 


\title{
DOES MEASURED SCHOOL QUALITY \\ REALLY MATTER? AN EXAMINATION OF \\ THE EARNINGS-QUALITY RELATIONSHIP
}

\begin{abstract}
This paper examines the economic and empirical foundations of the aggregate evidence
\end{abstract} on the effect of schooling quality on earnings. A common framework is presented which nests all previous studies as special cases. We discuss two crucial identifying assumptions and test them. The first assumption is the absence of region of birth - region of resident interactions in the return to schooling. This rules out patterns of migration on the basis of realized earnings in the destination state. Both parametric and nonparametric versions of this hypothesis are tested. Using 1970, 1980 and 1990 Census data, it is decisively rejected. A second assumption is that log earnings equations are linear - or nearly linear in schooling. This assumption is false. We find that estimated earnings-quality relationships are sensitive to specification of the earnings function. When false linearity assumptions are relaxed, the only effect of measured schooling quality is on the returns for college graduates. The evidence for an aggregate earnings-quality relationship is weak once false empirical restrictions are relaxed.

James Heckman

Department of Economics

University of Chicago

1126 East 59th Street

Chicago, IL 60637

and NBER

Petra Todd

Department of Economics

University of Chicago

1126 East 59th Street

Chicago, IL 60637
Anne Layne-Farrar

Department of Economics

University of Chicago

1126 East 59th Street

Chicago, IL 60637 


\section{A Brief Look at the History of the Schooling Quality Debate}

The relationship between educational expenditure and performance in the labor market has been the subject of much debate. Recent empirical studies find conflicting evidence on the extent to which spending on smaller classroom sizes, higher teacher salaries, or longer term lengths influences student educational attainment and labor market earnings.

Studies indicating an impact of schooling quality on earnings, such as the analyses of Johnson and Stafford (1973) and Card and Krueger (1992a,1992b), identify three distinct channels through which schooling inputs might affect earnings:

1. the effect of schooling quality on the intercept of log earnings equations

2. the effect of schooling quality on the "rate of return" to education (the coefficient on education in a schooling-log earnings relationship)

3. the effect of schooling quality on educational attainment and the consequent increase in earnings that accompanies higher levels of education.

The first effect increases earnings in the same proportion at all education levels. The second effect widens schooling-log earnings differentials. The third effect operates as a consequence of the first two. As the return to schooling increases, students undertake more of the activity.

Despite the accumulated evidence, many economists and most sociologists doubt that the earnings-quality relationship is strong. Beginning with the Coleman report (1966) and continuing in a literature reviewed by Hanushek (1986, 1989), numerous studies find no systematic relationship between quality and achievement test scores (see Betts, in this volume, and the discussion in Heckman and Neal, 1995). While the link between achievement test scores and earnings is not well understood, the evidence in this literature casts doubt on the existence of a strong quality-earnings relationship.

Several studies find that some of the strongest effects of schooling quality on earnings are observed for the oldest cohorts. However, our study will present contrary evidence. Some of the strongest estimated effects of quality are found for recent cohorts 
in the 1990 Census data - consistent with a rise in the return to schooling found since 1980 .

The observation in the literature of a declining coefficient for quality on the earnings of recent cohorts through 1980 is consistent with declining variability in school quality over time; there has been dramatic historical convergence across states towards higher schooling quality (see Figure 1 which graphs trends in pupil/teacher ratios over time). Regression methods require variability in the data in order to relate movements in one variable to movements in another. Hence, reduced variance in measures of schooling quality produces less precise estimates of quality impacts on earnings for more recent cohorts.

Weaker effects for younger cohorts could also be due to diminishing marginal pr ductivity of schooling quality. The demise of one-room school həuses and he elimination of the most egregious conditions in Southern black schools could substantially reduce marginal returns to schooling quality for later cohorts. These factors also explain why Hanushek and his co-authors find such strong effects of schooling quality in less developed countries, whereas Hanushek finds only weak effects for any schooling quality in recent US data. (see, e.g. Hanushek and Harbison, 1992).

Empirical estimates of the impact on quality on earnings are affected by the level of aggregation of the quality data. The strongest support for a quality effect is obtained when state-wide average measures of school quality are related to the earnings outcomes of individuals educated in that state. The weakest evidence is found when quality indicators from specific schools attended are used to establish a relationship. Since many parents make residential choices based, in part, on the quality of local schools, it is difficult to determine whether a child benefits from a high quality local school or whether he or she succeeds because of better family background and community environment. Therefore, establishing a quality-eamings relationship with individual level data requires the use of econometric techniques to eliminate potential sorting bias. Aggregated data are arguably less prone to sorting bias. However, if sorting bias is the reason for different estimated schooling quality effects, estimated micro relationships should be stronger, not weaker. The observed increase in the strength of the quality-earnings relationship with 
the level of aggregation of the quality measure runs counter to the sorting bias hypothesis but is consistent with claims that schooling quality data are measured with mean-zero measurement error that is averaged out in the aggregates.

One explanation for the variety of estimates that appear in the literature is differences in data sets and functional forms used to execute the empirical analyses. Different studies use different quality indices (for example, pupil-teacher ratios verses current expenditure) or different earnings measures (such as hourly wages versus annual income). Equally problematic are the diverse assumptions made about the specification of the quality-earnings relationship. With different equations estimated, different results can be expected. Because various studies measure conceptually different earnings-quality relationships, comparisons of estimates across studies are difficult if not impossible to make. ${ }^{1}$

\section{Continuing the Debate}

The lack of comparability of existing empirical studies is the primary motivation for this paper. We seek to resolve some of the discrepancies by developing an empirical framework sufficiently broad to encompass all of the models used in the main empirical literature. This enables us to make meaningful comparisons among studies and to clarify the assumptions required to identify the impact of quality on earnings. There are many channels through which quality can affect earnings. Previous empirical studies consider only a single channel through which quality affects earnings. We consider multiple channels of influence.

To gain insight into which of the models are consistent with the data, we conduct statistical tests of the validity of the assumptions used in previous empirical work. We point out a fundamental identifying assumption in the literature: the absence of region of

\footnotetext{
${ }^{1}$ Recently, researchers have tried to draw conclusions about the effects of schooling quality using "metaanalysis," a statistical approach for combining estimated quality effects across different studies. (for example, see Hedges, Laine and Greenwald (1994) and Card and Krueger (1994)). Prior to combining estimates by this statistical procedure, it should first be determined that model estimates are indeed comparable (and justifiable) in a theoretical sense, and this is rarely done because comparability is a subjective condition. Meta-analysis is a mechanical substitute for more careful empirical reanalysis of data and weighting of the evidence.
} 
birth - region of residence interactions in the returns to schooling. We find strong evidence of such interactions that is consistent with selective migration and pursuit of comparative advantage. This evidence calls into question a key identifying assumption of existing models, such as the one presented by Card and Krueger (1992b).

Using that study and features of an earlier study by Johnson and Stafford (1973) as points of departure, we find that estimated impacts of schooling quality on earnings are fragile with respect to the specification of the earnings function. Log earnings functions that are linear in years of education are commonly used in the literature. They are rejected by the data in favor of a model with "sheepskin" effects. ${ }^{2}$ Nonlinear models generally reveal that the only impact of quality on earnings is on the marginal increment to earnings arising from college attendance and graduation.

Our paper develops in the follow it 3 manner: Section I presents a general analysis of variance framework for studying the quality-earnings relationship. Within this framework, we compare different estimation strategies taken in the literature for determining the impact of schooling quality on earnings. Of particular interest is our examination of the identification strategy used in aggregate data studies, which relies on observations on migrants in different labor markets to provide crucial identifying information. We show that if individuals educated in particular states of birth have comparative advantage in the labor markets of particular states of residence, then this identification strategy breaks down.

In Section II, we discuss the sources of bias that may arise under the "aggregate data" and the "individual level data" approaches for estimating the effect of schooling quality on earnings. In Section III, we question the validity of a key identifying assumption invoked in aggregate data studies - that there are no patterns of migration on the basis of realized earnings in the destination state. Unfortunately, there is much evidence for selective migration.

In Section IV, we conduct nonparametric tests of the hypothesis that empirical measures of quality and earnings are monotonically related. The existing literature

\footnotetext{
${ }^{2}$ Sheepskin effects are discrete increases in the return to education that arise after completing a degree.
} 
assumes that quality is an immutable characteristic with unit increases in quality yielding the same return to schooling in all labor markets. In this case, we would expect that in a given labor market, at each education level, wages for workers born in high quality states should lie above those from low quality states. The results from nonparametric rank tests give little evidence of a relationship between the measured quality of schooling received by individuals and their wages. Selective migration is a prime candidate for explaining the non-monotonic relationship between earnings and schooling quality.

In Section $\mathrm{V}$, we examine the sensitivity of estimated schooling quality effects to alternative assumptions about functional forms of earnings equations. We highlight differences in the functional forms adopted in the schooling quality studies by Johnson and Stafford (1973) and Card and Krueger (1992b). We investigate the implications of various maintained assumptions, and conduct statistical tests to see whether the data support the assumptions. In addition to considering the effect of schooling quality on individual returns to education, our analysis presents new evidence on the effects of aggregate stocks of quality on aggregate pricing relationships.

We test - and reject - the widely used assumption that log earnings equations are linear in education, and instead find evidence of significant "sheepskin" effects, especially for completion of college. Using a more general model, we reestimate the quality-earnings relationship allowing for nonlinearities in the return to education. In this empirically more concordant model, the estimated impact of quality on earnings lessens considerably. The only support for the quality hypothesis comes through the marginal return for attending or completing college.

Section $V$ concludes by presenting estimates from an earnings model that allows for systematic differences in returns to schooling for persons born in different regions and living in different regions. Within this model, we relax the assumption that the effect of schooling quality on the rate of return to education is the same in all labor markets. This assumption is rejected for most quality measures. Different valuations of the same quality bundle may be a driving force behind selective migration, as individuals change locations to realize higher returns on their human capital. Relaxing the assumption of 
uniformity of quality effects on rates of return to schooling changes estimated quality effects, which generally weaken.

Our analysis does not prove that higher quality education is ineffective at enhancing worker productivity and earnings. Rather, it calls into question the strength of the evidence for a strong quality-earnings relationship based on aggregate data. Functional form plays a powerful role in generating this relationship. Estimated quality effects are highly sensitive to the assumption of linearity of the log-earnings function in years of schooling. They also depend on the particular channel of influence used to establish the quality-schooling relationship. Finally, schooling quality affects the return to education differently across different labor markets. If individuals migrate selectively to exploit economic opportunities, the identification strategy used in existing aggregate data studies breaks down.

\section{Organizing The Evidence}

\section{The Empirical Plan}

This paper reexamines existing empirical evidence and presents new evidence on the question of whether aggregate secondary schooling quality significantly affects individual earnings. To facilitate comparisons between our analysis and previous aggregate data studies, we use similar datasets. Our observations on individual earnings and demographic characteristics come from the 1970, 1980, and 1990 micro Census samples. The analysis samples consist of white men born in the US in the years 19101959 who worked at least one week and reported positive wage and salary income within a certain range. Our sample restrictions are identical to those used by Card and Krueger (1992a), who analyze cohorts of white men from the 1980 Census. $^{3}$

We determine the effect of schooling quality on earnings by relating individual level data on weekly wages to state level average measures of schooling inputs for the

\footnotetext{
${ }^{3}$ See section $\mathrm{V}$ for a detailed description of the data sources and Appendices $\mathrm{A}$ and $\mathrm{B}$ for additional information.
} 
years in which the individual would have attended school. It is assumed that individuals are educated in their state of birth. For example, a person born in Florida in the 1920-29 cohort is imputed an index of that states' schooling inputs averaged over the years in which his birth cohort attended school (1926-1947). The empirical measures of quality considered in our study are two measures of the pupil-teacher ratio (one based on pupil enrollment and one based on average daily attendance), term length, and relative teacher salary, all of which are derived from published biennial reports from the US Department of Education.

The strategy used in aggregate data studies to identify an impact of schooling quality on earnings is to compare the earnings of individuals living in the same state but educated in different states. The differential payment to persons from different states of birth is attributed to schooling quality and not, for example, to other common environmental influences or to the operation of selective migration. The analysis is usually conducted within a regression framework in which log earnings are regressed on measures of schooling quality and on additional variables to control for differences in demographic characteristics, labor market conditions, years of experience, and years of education. ${ }^{4}$

As shown in the next section, empirical strategies in the literature differ in the way the quality variable is introduced into the earnings model. For example, Johnson and Stafford (1973) assume that increases in schooling quality act uniformly across education groups: everyone born in a state with relatively high schooling quality receives an identical increase in their log earnings regardless of their state of residence or the number of years of schooling attended. An alternative assumption, suggested by Behrman and Birdsall (1983) and used in Card and Krueger's (1992a) study, is that schooling quality operates by increasing the return to education. This model maintains that individuals with higher levels of education receive more benefit from increases in schooling quality.

Our empirical analyses suggest that many of the earnings functions commonly adopted to model the quality-earnings relationship are too highly stylized; key

\footnotetext{
${ }^{4}$ Mincer(1974) provides a theoretical justification for using log earnings as the dependant variable instead of earnings levels in estimating earnings-schooling relationships.
} 
assumptions which identify a quality effect, when tested, are easily rejected by the data. For example, if a unit increase in quality is assumed to have the same effect on the rate of return in all states of residence, an implicit assumption is being made that individuals' residential choices are unrelated to the quality of their education. There is considerable evidence against the assumption of a common effect of a unit change in quality on the rate of return to schooling in all regions. The empirical evidence also indicates that individuals from certain states of birth have comparative advantages in certain states of residence to which they tend to migrate. Also of questionable validity are the assumptions often made that the log earnings relationship is linear in education and that schooling quality affects earnings through a single, easily specified channel, such as the rate of return to education. The next section shows the variety of ways in which schooling quality might be expected to influence an individual's earnings.

Throughout this paper and in the entire literature, the quality of schooling available to persons is taken as exogenously given. There is no systematic discussion of the political economy of the determination of schooling quality or of migration of families across political jurisdictions, either in pursuit of better schooling quality or to avoid the costs of paying for higher schooling quality.

\section{The Framework For Organizing The Evidence}

For the purpose of comparing the various earnings model. adopted in the literature, it is useful to develop a more general framework for thinking about the relationship between earnings and schooling quality. Express the logarithm of earnings of individual $i$ born in state $b$, in birth cohort $c$, residing in state $s$ as

$$
\begin{aligned}
& y_{i s b c}=\tilde{\theta}_{s b c}+X_{i s b c} \tilde{\beta}_{s b c}+E_{i s b c} \tilde{\alpha}_{s b c}+\varepsilon_{i s b c} \\
& i=1, \ldots, I, \quad s=1, \ldots, S ; \quad b=1, \ldots, B, \quad c=1, \ldots, C,
\end{aligned}
$$

where $\widetilde{\theta}_{s b c}$ is an intercept term, $E_{i s b c}$ is education - which may be a vector or a scalar and $\tilde{\alpha}_{s b c}$ is the associated regression coefficient. It is more familiar to think of $E$ as a scalar determinant of earnings, but our analysis can readily be extended to the vector 
case, and we do so in some of empirical work. $X_{i s b c}$ represents other regressors, such as work experience, which can be parameterized in a symmetric fashion. $\varepsilon_{i s b c}$ is a mean zero variable unobserved by the analyst that may or may not be known to person $i$.

As a model of mean earnings, equation (1) is quite general. If $E_{i s b c}$ were a vector of dummy variables indicating different levels of educational attainment, (1) would impose no restrictions on mean earnings at all. Each education - state of residence - state of birth - cohort of birth cell would be fully described by (1). Linearity of log earnings in years of schooling, $E$, imposes a strong restriction, which in fact is rejected by the data.

Both the intercept and the slopes can be decomposed into an analysis of variance structure: $:^{5}$

$$
\begin{aligned}
& \tilde{\theta}_{s b c}=\theta_{s}+\theta_{b}+\theta_{c}+\theta_{b c}+\theta_{s c}+\theta_{s b}+\theta_{s b c} \\
& \tilde{\alpha}_{s b c}=\alpha_{s}+\alpha_{b}+\alpha_{c}+\alpha_{b c}+\alpha_{s c}+\alpha_{s b}+\alpha_{s b c} \\
& \tilde{\beta}_{s b c}=\beta_{s}+\beta_{b}+\beta_{c}+\beta_{b c}+\beta_{s c}+\beta_{s b}+\beta_{s b c}
\end{aligned} .
$$

For simplicity, we restrict $\beta$ to be identical in all cells, allowing only for cohort effects, $\beta_{c}$. We recognize the peculiar asymmetry that this implies but follow the literature in adopting this convention. In other work, we relax this assumption and find that doing so affects estimates of the effect of quality on the return to education (Heckman, LayneFarrar and Todd, 1995). Conventional regression normalizations of the analysis of variance are adopted to measure effects relative to omitted base state characteristics.

Aggregate studies of schooling quality measure it at the geographic level and assume that a common quality component applies to all persons bom in state $b$ in cohort c. The most general analysis of variance form of model (1),(2) and (3a) is fully saturated so that there are no remaining degrees of freedom to estimate a quality effect on earnings. To make "room" for such an effect, and estimate the effect of quality on earnings, restrictions have to be imposed on the model. Empirical studies in the literature differ in the way quality is assumed to operate on earnings. For example, if schooling quality is an

\footnotetext{
${ }^{5}$ Residuals terms could be introduced to both the slope and the intercept equation to put this model in a random coefficient framework.
} 
additive component operating independently of the level of education - as in the JohnsonStafford model - then it operates solely through $\theta$.

Schooling quality could also operate through the slope coefficients. A prototypical restriction is the one used by Card and Krueger (1992b):

$$
\alpha_{b c}=Q_{b c} \varphi
$$

where state of birth fixed effects and cohort fixed effects for slope coefficients are absorbed into $\alpha_{b}$ and $\alpha_{c}$. More general models in quality could be fit as long as the (B- 1) (C - 1) degrees of freedom in $\alpha_{b c}$ are not exhausted.

Seeking to avoid bias using a standard "fixed effects" strategy, Card and Krueger do not report estimates of the effect of quality operating through the intercepts in the model (the $\theta$ ). They include $b$ and $c$ specific intercepts to control for factors such as family income that differ across states of birth and are also likely to affect individual earnings. In some of their specifications, they also entertain the possibility that such factors might also operate on slopes. Thus they remove state of birth and cohort specific effects from both the slopes and intercepts of their model.

Quality can determine earnings through other channels. The average quality of persons in a labor market could affect earnings through an aggregate supply effect on factor prices. In this case, the state of residence-specific components (both the levels $\left(\theta_{s}, \theta_{s c}\right)$ and slopes $\left.\left(\alpha_{s}, \alpha_{s c}\right)\right)$ would be functions of the total amount of quality employed in the market. Since most studies in the literature focus on only one possible channel through which quality operates, they understate or overstate the contribution of quality to earnings, depending on whether quality increases or decreases the neglected components of the pricing equation. Below, we present some evidence that increasing the total supply of quality in a state depresses the marginal price of skill.

Aggregate schooling quality is just one of several aggregate economic variables that are plausible determinants of state of residence effects (variables with s-subscripts). In section V, and in a companion paper (Heckman, Layne-Farrar and Todd, 1995), we present new evidence on the impact of aggregate stocks of human capital, physical capital, industrial structure and schooling quality on state-wide and regional earnings 
equations. Aggregate economic variables play an important role in determining pricing equations for labor services.

Any empirical study requires that limits be placed on the scope of the work. At issue is how important these limits are in practice. Both Johnson and Stafford, and Card and Krueger assume that there is no interaction effect between state of birth and the state of residence, i.e. that $\theta_{s h}=0, \theta_{\mathrm{sbc}}=0$ and $\alpha_{s b}=0, \alpha_{\mathrm{sbc}}=0$. As noted in the next section, this assumption implies that the return to quality (the coefficient of quality in a log earnings equation) is the same for any state of residence. It also rules out selective migration by individuals from states of birth to states of residence in response to the level of realized earnings in the state. Both studies also assume that the relationship between log earnings and education is linear. 6 In addition, Johnson and Stafford postulate that the slope parameter on education is the same across all states of birth and states of residence $\left(\alpha_{b}=0\right.$, $\alpha_{s}=0, \alpha_{s b}=0, \alpha_{s c}=0, \alpha_{b c}=0, \alpha_{s b c}=0$ ). Any one of these restrictions could influence estimated quality effects estimated. Later, and in our companion paper, we test for the validity of each of these assumptions and find that most are rejected by the data. When these assumptions are relaxed, a different picture of the impact of schooling quality on earnings emerges.

Two tables clarify table clarifies Card and Krueger's identification strategy and our evidence against it. For simplicity consider only a single cohort and a given level of education, say 12 years. Let $\bar{y}_{s b}$ be the mean log earnings for people born in $\mathrm{b}$ and living in s. Imagine a $\mathrm{S} \times \mathrm{B}$ table of means as depicted in Table 1(a).

\footnotetext{
${ }^{6}$ Card and Krueger assume that the estimated relationship is linear after the second percentile of the education distribution within each state.
} 
Table 1(a)

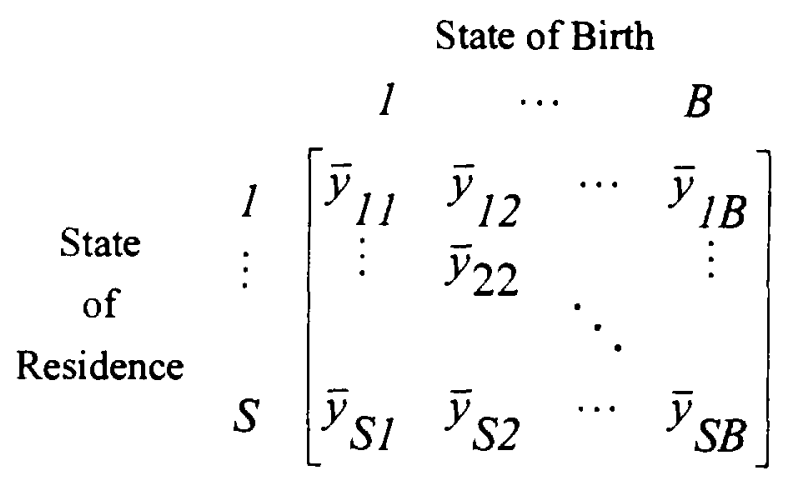

If all people who are born in $b$ remain in $b$ their entire lifetime the table tooks like this:

Table 1(b)

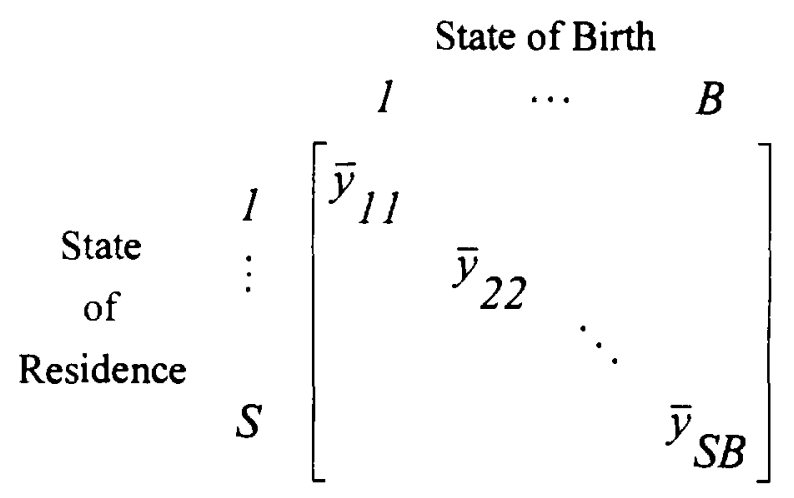

All the information in the table is on the diagonal.

Assuming an additive model, mean earnings can be written as,

$$
\bar{y}_{s b}=\mu+\alpha_{b}+\beta_{s}
$$

where $\alpha_{b}$ is a state of birth effect and $\beta_{s}$ is a state of residence effect. This model assumes that there is a state of birth effect common to persons from different states of residence and a state of residence effect common to persons from different states of birth. If no one migrates, then all $b=s$ and we can never separate $\alpha_{b}$ from $\beta_{s}$, ie, state economy specific factors would be confounded with state-specific quality factors such as parental background or pupil-teacher ratios. 
To identify a state of birth endowment effect, $\alpha_{b}$, which is usually assumed to be generated by schooling quality, it is necessary to have information on the off diagonal terms. If there are two or more state of birth cohorts residing in a state of residence $\mathrm{s}$, we can eliminate the common state of residence effect to identify $\alpha_{b}$ relative to $\alpha_{b}$, for two states of birth $b$ and $b^{\prime}$ :

$$
\begin{aligned}
& \bar{y}_{b, s}=\mu+\alpha_{b}+\beta_{s} \\
& \bar{y}_{b^{\prime}, s}=\mu+\alpha_{b^{\prime}}+\beta_{s}
\end{aligned}
$$

so

$$
\bar{y}_{b, s}-\bar{y}_{b^{\prime}, s}=\alpha_{b}-\alpha_{b^{\prime},{ }^{7}}
$$

One could identify the change in the value of $\alpha_{b}$ from one state of birth to another using $\alpha_{b}-\alpha_{b^{\prime}}$ so estimated. In some specifications considered by Card and Krueger, this is what is done, and $\alpha_{b}$ is parameterized as a function of quality in the state of birth $\mathrm{Q}_{b}$. When there is information on more than one cohort, one can estimate $\alpha_{b}$ for each cohort, $\tilde{\alpha}_{h c}$, where it should be recalled that " $\sim$ " denotes the raw data on the interaction before main effects are eliminated. Taking deviations of $\tilde{\alpha}_{h c}$ around cohort and state of birth means gives,

$$
\tilde{\alpha}_{b c}-\alpha_{h}-\alpha_{c}=\alpha_{b c}
$$

where $\alpha_{b c}$ was defined earlier in equation 3(a). Card and Krueger assume that this interaction is a linear function of the quality of education for each cohort $(c)\left(Q_{b c}\right)$ so

$$
\alpha_{b c}=\varphi Q_{b c}
$$

$\varphi$ is identified by comparing two or more states of birth

$$
\text { i.e. }\left({ }^{* *}\right) \quad \alpha_{b c}-\alpha_{b^{\prime} c}=\varphi\left(Q_{b c}-Q_{b^{\prime} c}\right) \text {, }
$$

or by comparing any two state of birth cohorts, e.g.

$$
\alpha_{b c}-\alpha_{b c^{\prime}}=\varphi\left(Q_{b c}-Q_{b c^{\prime}}\right)
$$

or

$$
\alpha_{b c}-\alpha_{b^{\prime} c^{\prime \prime}}=\varphi\left(Q_{b c}-Q_{b^{\prime} c^{\prime \prime}}\right)
$$

${ }^{7}$ Assuming the normalizations $\sum_{b} \alpha_{b}=0$ and $\sum_{s} \beta_{s}=0$ identifies each component relative to $\mu$. Otherwise, the components are identified relative to an omitted category. 
By dividing the left hand side by the quality contrast, $\varphi$ can be identified. In fact, it is clear that if the contrasts are taken only within cohorts, a c-specific $\varphi, \varphi_{c}$, can be identified. If contrasts are taken within states of birth, a b-specific $\varphi, \varphi_{b}$, could be estimated.

Crucial to the Card-Krueger strategy is the assumption that there are no interactions between state of birth and state of residence i.e. that in a model with interaction

$$
\bar{y}_{b s}=\mu+\alpha_{b}+\beta_{s}+\Delta_{b s},
$$

$\Delta_{\mathrm{bs}}=0$. If this is not true, then

$$
\bar{y}_{h, s}-\bar{y}_{h^{\prime}, s}=\alpha_{h}-\alpha_{h^{\prime}}+\Delta_{h s}-\Delta_{h, s} .
$$

Estimated relative state of birth effects now depend on particular choices of the states of residence. Although unlikely, it might so happen that a model like $\left(^{* *}\right)$ could still be true if unit increases in quality had the same effect on the rate of return across all states of residence. That is a testable restriction which we reject in 1970,1980 and 1990. More generally, we test for the absence of interaction $\left(\Delta_{b s}=0\right)$ and reject it in all years we consider. The presence of such an interaction is consistent with patterns of comparative advantage for individuals from certain states of birth in certain states of residence, that induce individuals to migrate to exploit favorable economic opportunities. ${ }^{8}$

Allowing for non-zero interaction $\left(\Delta_{\mathrm{bs}} \neq 0\right)$ greatly affects inferences about the size, sign and statistical significance of estimates of schooling quality on the return to schooling as we note below.

\section{A Comparison of the Aggregate and Individual Level Data Approaches}

Previous empirical studies of the quality-earnings relationship can be broadly classified as following either the "aggregate data" approach or the "individual level data" approach. Under the individual level data approach, individual earnings are related to quality indicators from the school actually attended by the individual. The aggregate

\footnotetext{
${ }^{8}$ See, e.g. Heckman and Scheinkman (1987) or Rosen (1983) for discussions of how non-uniform pricing of attributes across sectors in an economy gives rise to the problem of self-selection. Heckman and Scheinkman present empirical evidence against uniform pricing in the U.S. economy.
} 
approach relates individual earnings to state or area-wide averages of school quality. In addition, earnings data are sometimes aggregated as well.

The main criticism directed against the individual level data approach is that estimates of the effect of quality on earnings are subject to the problem of "sorting bias." The quality of a person's schooling tends to be correlated with family background characteristics. In a regression of earnings on schooling quality, if variables such as family background affect earnings but are omitted from the analysis, then part of their effect will be wrongly attributed to quality. ${ }^{9}$ Researchers attempt to control for sorting bias by including variables in the regression like family income or parental education to proxy for family background, but estimates are nevertheless subject to the uncertainty that the control variables may be inadequate for removing the bias.

The aggregate data approach is sometimes promoted as a remedy for the sorting bias problem. By averaging quality variables over large enough areas (such as by school district or by state), there is likely to be less correlation between the quality measure and family background effects, which mitigates the selection problem. However, in light of the empirical evidence this claim is implausible. Because the micro level studies wrongly attribute some of the family background effect to quality, estimates from the micro studies should provide stronger support for the quality hypothesis than the estimates based on aggregate quality measures. Yet in practice, the opposite occurs: the aggregate studies show a stronger effect of schooling quality on earnings than individual level studies.

Evidence of stronger estimated effects of school quality on earnings and test scores as the level of aggregation in the school quality measure increases (from schools to states) is consistent with a story that emphasizes measurement error in schooling quality that is averaged out in state aggregates (Betts, in this volume; Hanushek et.al, 1994). It is not consistent, however, with plausible models of sorting in response to quality differentials. Almost all of empirical studies, including those by Johnson and Stafford (1973) and Card and Krueger (1992a), assume that quality is exogenously determined. But this assumption

\footnotetext{
${ }^{9}$ The coefficient on quality will be upward biased when the omitted variables positively affect earnings and are positively correlated with quality.
} 
is a dubious one given the established connections between family background and education. A more complete account of the impact of schooling quality on earnings would close the model by including an analysis of how quality is determined. Evidence that aggregate measures of quality produce stronger effects of quality in equations estimated on micro data is not consistent with a story of quality determined by schools and parents unless redistribution across school districts is against high-achieving students. If school authorities choose to award high-achieving students (or schools) with more resources, and resources raise outcomes, averaging the data should weaken and not strengthen estimated input-output relationships. ${ }^{10}$ Assumptions about how quality is determined are key to interpreting the results in any analysis of the schooling quality-earnings hypothesis.

\section{Migration: The Source of Identifying Information in Aggregate Data Models}

Sorting bias and measurement error are not the only problems that arise in identifying the impact of schooling quality on earnings. Differences in earnings among individuals with the same educational attainment level could be due to differences in ability, regional differences in cost of living, or regional differences in production technologies. Shifts in demand and supply for different types of human capital can also affect earnings. Finally, individuals can change their earnings simply by moving to different locations. Our ability to isolate the effect of quality on earnings depends on our ability to control for all of these other relevant determinants of earnings.

As noted in the discussion surrounding tables 1(a) and 1(b), earnings data on migrants are essential in identifying the impact of schooling quality on earnings using the aggregate approach. Recall that if there is no migration across states, one cannot isolate a quality effect from other state - specific effects. If we only observe earnings for people born in a state and living in it, earnings differentials could be due to cost of living, technology, or demand and supply effects that vary across states.

Random migration across states produces exogenous variation in quality and a quality effect on earnings can be identified. This is the most favorable case for the

${ }^{10}$ See Heckman, Layne-Farrar, and Todd (1995) for a model of quality determination that reconciles the literature's unusual finding of stronger quality effects for higher levels aggregation in the data. 
aggregate data approach. If migration is nonrandom, however, it is necessary to distinguish state of residence effects from quality effects. The two are conflated.

To see why, it is fruitful to examine the factors likely to influence a person's decision to migrate. If prices of productivity attributes are uniform across all states, no one has an incentive to migrate. One can earn the same income in all locations ${ }^{11}$. Below, we present evidence against this assumption. If it is not satisfied, migrants will take into account their expectation of their prospective earnings in alternative destination regions. The expected gain from migration depends on the prices of attributes, which are determined from state aggregates through demand and supply forces. For example, if a state experiences an increase in the demand for skilled labor, we would expect to see migration from states producing higher schooling quality to states demanding the skills, if those states are different. There could be a pattern of educational selectivity among migrants, which has often been noted. For example, Hamilton (1959) observes that over the period 1940-1950 outmigrants from the South tend to come from the lower and upper ends of the education distribution. Of these migrants, the relatively better educated went to the North and the more poorly educated moved to the West.

Table 2, which compares the wages and quality of migrants with those of nonmigrants, reveals a pattern of selective migration. ${ }^{12}$ For the majority of cohorts and education levels, migrants' wages exceed natives' wages. Migrants' average schooling quality is generally higher as well, although this relationship is weaker than the relationship for wages. If migration were random, there should be no systematic difference between the weekly wages of migrants and nonmigrants. Table 3 , using just the 1980 Census data, summarizes the migration patterns of persons born in different regions and provides the strongest evidence against the assumption of random migration. Persons born in a region are much more likely to live in it. This relationship is strongest for persons with less education and for persons born in the Pacific region. Moreover, among persons who move, the pattern of regional migration is not the same for all regions of birth.

11 After allowing for differences in earnings levels due to differences in amenities across regions.

12 See section $V$ for a discussion of the data sources, or Appendices $A$ and $B$ for detailed information. 
Given persuasive evidence in favor of selective migration, and the evidence we present below that quality and education are priced differently in different regions, estimated quality effects produced from models that assume that migration is random are questionable unless one can claim that all relevant factors determining earnings are adequately controlled in estimated earning functions. In section $\mathrm{V}$, we estimate alternative specifications of earnings equations to account for migration. But first we examine the quality-earnings relationship more closely.

\section{Testing Monotonicity of the Quality - Earnings Relationship}

The central premise of the quality-earnings hypothesis is that higher quality schooling produces higher earnings. In Table 1(a), the column associated with the state with the highest birth quality should be bigger, element by element, than any other column in the table. This premise alone is almost a tautology, because "quality" per se is something that yields a positive benefit to the recipient - in this case higher earnings. To make the premise empirically interesting, we must further assume that quality levels can be measured in terms of such indices as pupil-teacher ratios, teacher salaries, and term lengths. We can then devise tests for the hypothesis, since the variables in question are observable.

If we assume that quality has a uniform effect on log earnings at all education levels (as in the Johnson and Stafford model described in Section I), then it follows that within every education level, the wages of persons with different levels of schooling quality should be ranked according to their quality rankings. This can be seen in the following diagram, where we assume that New York's schooling quality is higher than that of Alabama: 
Figure 2(a): Comparison of Wages of Persons with Different School Quality Levels

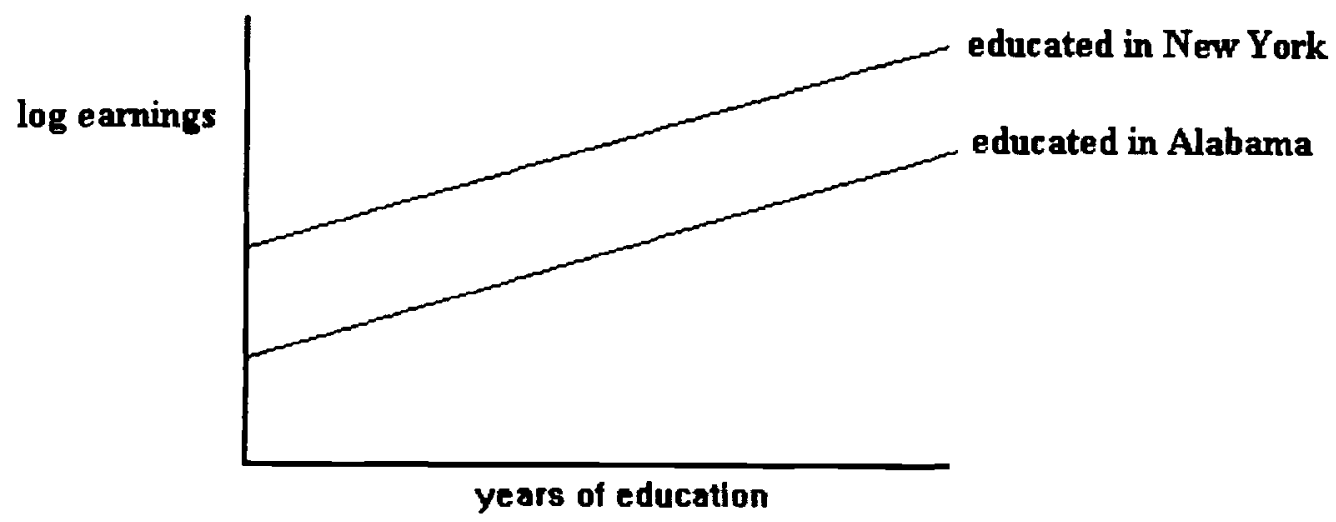

However, if we assume that the effect of quality operates by increasing the rate of return to education (the slope parameter) and also affects intercepts, then it could happen that the ranks by schooling quality and ranks by wages would not coincide at all education levels. Figure 2(b) shows how this might occur ${ }^{13}$. However, an implication of the Card-Krueger model is that at any education level, the ranks by state of birth would be the same in all labor markets.

Figure 2(b): Comparison of Wages of Persons with Different School Quality Levels

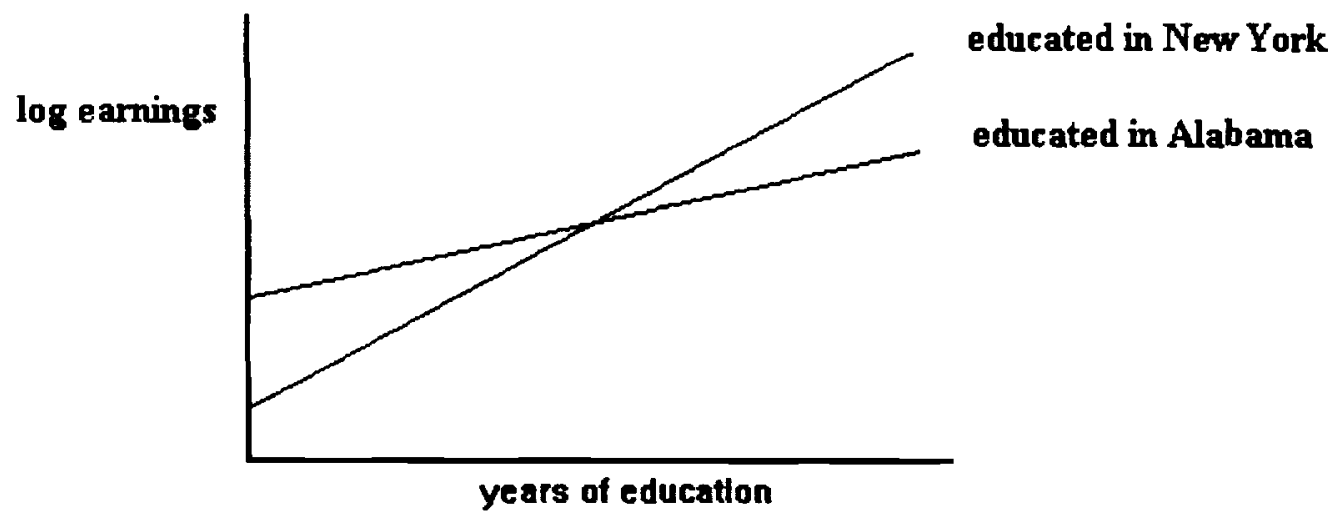

${ }^{13}$ We thank Gary Burtless for clarifying comments on these points. 
In figure $2 b$, the slope is higher in New York but the intercept is lower. Nonetheless, at a given level of education, the relative ranks of New York - and Alabama - born persons should remain the same across all labor markets.

This discussion suggests the two rank tests that we perform in this section: (a) tests that rankings in wage distributions correlate with rankings in quality distributions and (b) the weaker test that relative rankings by state of birth within education levels should be the same in all states of residence. Both are implications of the assumed absence of selective migration on the basis of realized earnings.

We now present evidence from the rankings of quality and wages across state and regional labor markets. The evidence generally supports the key idea in Figure $2 \mathrm{a}-$ that the lines do not cross - but does not support the hypothesis that the height of the noninteresting lines is positively - or negatively - related to schooling quality or that the ranks by state of birth within state earnings distributions are the same for all states at any level of educational attainment. Thus Figure 2(c), showing no systematic relationship between measured quality and earnings, is a more appropriate summary of our evidence, where Connecticut is assumed to have the highest quality of schooling and Alabama the lowest. Different returns to education for different states of birth may result from common environmental influences, from the operation of selective migration, or from schooling quality that is not captured by our indices. 
Figure 2(c): Comparison of Wages of Persons with Different School Quality Levels

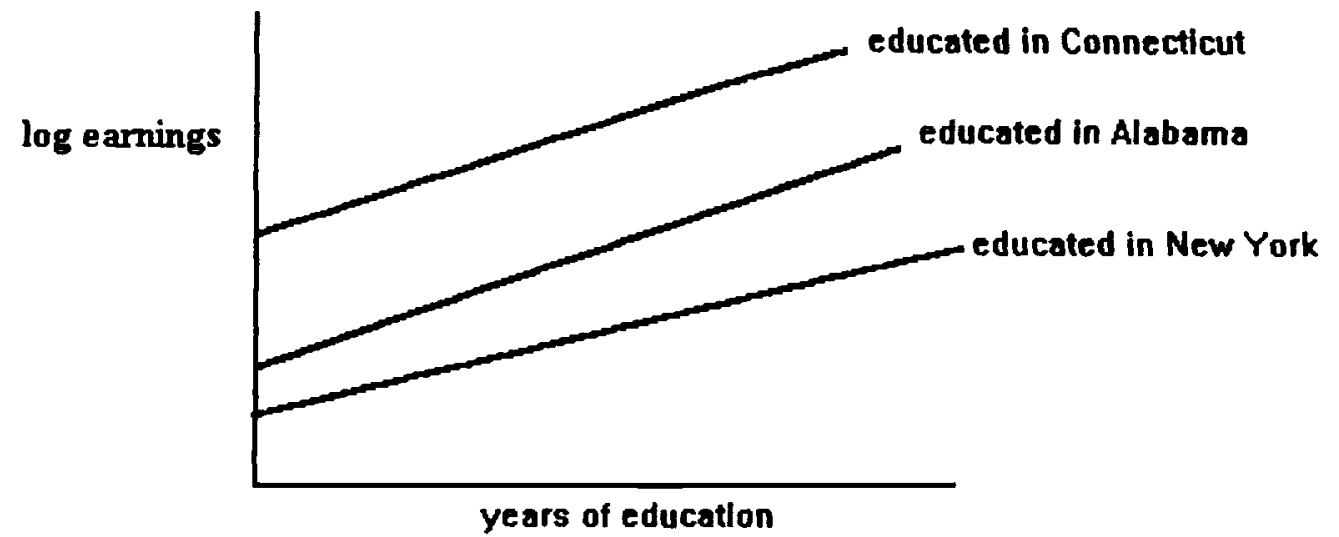

Table $4 \mathrm{a}$ and $4 \mathrm{~b}$ display Kendall-Tau correlations (with p-values in parentheses) between the rankings of four different quality measures and mean wages for individuals with 12 and 16 years of education, respectively. Correlations are calculated separately within regions of residence to allow for cost of living differences. ${ }^{14}$ The results show no support for a relationship between the quality rankings and the mean wage rankings. Tests based on median instead of mean earnings yield similar results.

It is useful to ask what explanations are consistent with our finding of no correlation between quality and wage rankings. One possible explanation is that states differ in their production technologies for transforming schooling inputs (the variables that are measured in the literature) into the output, quality education. This notion is consistent with Hanushek's (1986) observation that efficiency in translating educational inputs into outputs, and not just the absolute level of inputs, is important. The level of efficiency can vary across states. It may be affected by factors such as the strength of teacher unions, state laws governing education, and individual teacher proficiency. State education quality-earnings production functions may not be monotonic in quality.

Selective migration based on prospective gains and individual-specific costs is another possible explanation for the observed patterns. Suppose that persons born in

\footnotetext{
14 The p-value is the smallest level of significance at which the null hypothesis would be rejected. A low $p$-value indicates that the departure of the test statistic from the value specified by the null is an unlikely event under the null and therefore leads to its rejection.
} 
different regions receive different quality endowments, face different costs of migrating, and expect different payoffs in destination regions. Even if higher schooling quality raises productivity in all regions, the pattem of migration choices need not imply strict dominance of the wages of persons from high quality origins in all destination regions. Persons migrating long distances will tend to have higher earnings in all destination regions than those persons making short moves or no moves at all. The results we presented earlier in Tables 2 and 3 are consistent with this hypothesis. While we find that migrants' wages consistently lie above nonmigrants', no strong link with schooling quality is evident.

Nonmonotonic school quality-earnings relationships, the operation of selective migration, or measurement error in the quality indices could account for the lack of correlation between wage and quality rankings. This evidence casts doubt both on the empirical validity of simple quality of schooling models and on the existence of invariant schooling quality measures that successfully predict relative success in different economic environments.

If schooling quality determines ranks in wages but cannot be measured by our indices, or if the reversal depicted in Figure 2(b) is conceivable, it is still possible to test a weaker form of the quality-earnings hypothesis nonparametrically. If the hypothesis is true, and there is no selective migration, persons at a given education level from a particular state of birth will tend to have the same relative rank in the wage distributions across all regions of residence. ${ }^{15}$ The quality hypothesis would predict invariance in the state-of-birth wage rankings across all regions of residence for each education level under either of the wage-education relationships depicted in Figures 2(a)-(b). Table 5 presents Kendall Coefficient of Concordance statistics (and p-values) for stability in the region of birth wage rankings across regions of residence and provides some support for this implication of the hypothesis. The 1990 Census data show the strongest support for stability in the rankings with several significant p-values. Thus, wille rankings of the widely used empirical measures of schooling quality and earnings appear to be

\footnotetext{
15 When making wage comparisons across different labor markets, rank comparisons are much more robust than level comparisons, since they are not sensitive to regional differences in costs of living.
} 
uncorrelated, rankings of earnings by region of birth show some evidence of stability. The stability of the ranks is consistent with unobserved quality producing a stable earnings relationship and in this sense is consistent with the schooling quality model. The evidence is, of course, also consistent with a model that unobserved family background or income effects determine earnings. Any variable that differs across states of birth is a candidate for explaining this relationship.

It is striking that the measures used in the literature to establish a schooling quality-earnings relationship do not survive a nonparametric test. This rejection of the schooling quality hypothesis suggests that the earnings-schooling quality relationships reported in the literature may be artifacts of arbitrary functional form assumptions or other empirical procedures. Keeping this evidence in mind, we next examine the models used in two representative studies of schooling quality that find significant effects of measured school quality variables on earnings. We focus on the question of choosing an appropriate functional form for the earnings-quality relationship.

\section{An Empirical Exploration of Two Representative Models}

Empirical studies using different functional forms find different effects of schooling quality on earnings. To gain an understanding of how sensitive estimated effects are to changes in model specification, we examine two representative models. The first is that of Card and Krueger (1992a) and the second is a version of their model adapted to accommodate certain features of the Johnson-Stafford (1973) model. Both studies identify quality effects using aggregated data.

\section{Description of the Data}

As mentioned in section I, our data come from the 1970,1980 and 1990 Census samples. To maintain close comparability between our results and those of Card and Krueger (1992a), we replicate as closely as possible their 1980 Census samples and construct samples from the 1970 and 1990 Censuses in the same way. Our study focuses on white males from five birth cohorts: $1910-19,1920-29,1930-39,1940-49$, and 195059. Appendix A summarizes the sample exclusion restrictions and gives exact sample 
sizes for the different extractions. The sample sizes for the micro-data regressions are quite large, ranging from around 100,000 to nearly 600,000 .

Our study draws upon state-level data quantifying three broad aspects of schooling quality for full-time public secondary day schools (grades K-12): average term length, average annual instructional staff salary, and pupil-teacher ratios. For the most part, our quality data come from the Biennial Survey of Education. The data sources, as well as descriptions of the quality variables, are given in detail in Appendix B. ${ }^{16}$ We consider two measures of the pupil-teacher ratio - one based on pupil enrollment and one based on average daily attendance. For the earlier cohorts, who were not subject to mandatory schooling laws, and for more rural areas with family farming demands, the attendance based measure is probably a better proxy for true quality. ${ }^{17}$

A fundamental problem in establishing an empirical quality-eamings relationship is the difficulty in obtaining consistent measures of schooling quality. The commonlyused indices are sometimes inversely related to one another. If budget constraints are binding, as teacher salaries rise, there should be a concurrent increase in classroom size. That is, one measure would indicate an improvement in quality while another indicates a decline. We present evidence demonstrating conflicts among alternative measures of quality in Table 6. Alternative measures are not always positively correlated and even when they are, the correlation is far from perfect.

\section{Specific Functional Forms: The Card and Krueger Model}

Card and Krueger postulate a linear equation for log weekly earnings, $y$. In their specification, $y$ depends on a person's state of birth $(b)$, state of residence $(s)$, years of education $(E)$, and several demographic variables $(X)$. Their definition of education is somewhat unusual: $E$ is the years of education above the level attained by the bottom $2 \%$ of people in the education distribution. The demographic variables included in $X$ are a

\footnotetext{
16 We use a different regional deflator from that used by Card and Krueger to construct our relative teacher salary measure. Also, we use a term length measure that refers only to whites for the states that report a race specific measure. These differences are discussed in detail in Appendix B.

17 Most state mandatory school attendance laws were not passed until the early 1920s. Sometimes state or district educational funding depended upon enrollment, in which case there was an incentive for schools to inflate enrollment numbers.
} 
marital status indicator, potential work experience, potential work experience squared, and an indicator for whether an individual resides in a metropolitan area. The earnings function for individual $i$ is written as:

$$
\begin{aligned}
& y_{i s b c}=\delta_{h c}+\mu_{c c}+X_{c c} \cdot \beta_{c}+E_{b b c} \cdot\left(\gamma_{h c}+\rho_{r c}\right)+\varepsilon_{i b s c} \\
& E_{i b c}=\operatorname{Max}\left(e_{i b c}-T_{b c}, 0\right)
\end{aligned}
$$

- $i$ refers to the individual, $b$ to the state of birth, $s$ to the state of residence, $r$ to the region of residence (The nine regions defined by the Census are geographically contiguous groups of states), and $c$ to the birth cohort

- $e_{i b s c}$ is the actual number of years of schooling completed, $T_{b c}$ is the bottom second percentile of the education distribution for men born in state $b$ of cohort $c$

- $\gamma_{b c}$ is the "return" to education for an individual born in state $b$ in cohort $c$

- $\delta_{b c}$ captures the cohort-specific fixed effect for state of birth $b$

- $\mu_{s c}$ represents a cohort-specific fixed effect for state of residence $s$

- $\rho_{r c}$ is a region of residence effect which is meant to capture regional labor market shocks to the return to education. The region of residence coefficients are normalized to give deviations around a national mean.

- $\varepsilon_{i b s c}$ is a stochastic error term assumed to be identically and independently distributed (i.i.d.) across individuals

Using a model of the impact of quality on earnings suggested by Behrman and Birdsall (1983), Card and Krueger introduce schooling quality into the earnings function by assuming that quality increases the rate of return to education, $\gamma_{b c}$ They posit a linear relationship between the rate of return for individuals born in state $b$ in cohort $c$ and educational quality $\left(Q_{b c}\right)$, as measured by the pupil-teacher ratio, term length and teacher salary:

\footnotetext{
${ }^{18}$ Card and Krueger set $\sum_{r} f_{c} \cdot \rho_{r c}=0$, where $f_{r c}$ is the fraction of cohort $c$ living in one of the nine Census regions. Therefore, the $\gamma_{b c}$ parameter includes the national cohort mean education return.
} 


$$
\gamma_{b c}=\alpha_{b}+\alpha_{c}+Q_{b c} \cdot \varphi
$$

The return to education is allowed to depend on the state of birth (through fixed effects $\alpha_{b}$ ) and on the cohort (through $\alpha_{c}$ ), but the marginal effect of quality is assumed to be the same for all birth cohorts and for all states of birth. The key parameter in the quality-earnings relationship is " $\varphi$ ". Estimates of $\varphi$ are obtained from a two-stage procedure regressing estimates of $\gamma_{b c}$ on $Q_{b c}$.

Several features of this specification are noteworthy. First, observe that the parameterization of work experience (included in $X_{i c}$ ) is not symmetric with respect to the parameterization of education. The effect of experience is permitted to vary by birth cohorts but not across states of birth, as is the case for education. Since work experience is a form of human capital that is complementary with formal schooling, and participation in formal schooling increases the rate of accumulation of job training (Mincer, 1974), it is not obvious that it should be treated asymmetrically. When we parameterize experience more generally, we find that estimated schooling quality effects operating through the return to education weaken, but there is little evidence of a quality effect operating through estimated returns to work experience. ${ }^{19}$

Second, this model assumes that the log earnings-quality relationship is linear above a $2 \%$ threshold, and that there is no return to education until the $2 \%$ level. ${ }^{20}$ Below, we test and reject the assumption that earnings is linear in education for all three Census years. In the data, there is evidence of "sheepskin effects" - discrete jumps in the return to education upon completion of a degree. When the linearity assumption is relaxed to account for these effects, the only support for an effect of school quality on earnings comes through the marginal return to college attendance.

Third, the specification in (4) rules out state of birth-region of residence interactions both in slopes and intercepts. We test this hypothesis and reject it. There are

\footnotetext{
${ }^{19}$ See Heckman, Layne-Farrar and Todd (1995) for this evidence.

20 The second percentile of most states for the later cohorts is around 8-9 years of education. In our sensitivity analysis, we find that assuming linearity above a $2 \%$ threshold verses assuming linearity in actual years of education makes little difference to the estimated effects of quality.
} 
differential returns to skills, including quality, across different regions. Differential pricing of individual productivity attributes, such as quality, could induce selective migration, in which case the residual, $\varepsilon_{i s b c}$, is unlikely to be exogenous with respect to state and region of residence indicators. When we estimate a model that includes interactions between region of birth and region of residence to account for nonrandom migration decisions, estimated effects of schooling quality often reverse sign or become imprecisely determined.

Fourth, the specification in (4) assumes that returns to education are regionspecific. The addition of an education-specific regional component to the education return is a valuable contribution of the Card-Krueger model. We test and do not reject the hypothesis that returns are region-specific. However, when we allow for nonlinearity in the earnings equation, we reject this specification for higher (post 12 years) levels of education. For persons with college degrees there is a national labor market; regional labor market effects are unimportant. Heckman, Layne-Farrar and Todd (1995) examine the theoretical implications of the evidence of statistically significant education-specific regional interaction effects for conventional "efficiency units" models of labor quality. We reject the "efficiency units" specification of labor input and other common specifications of the pricing of labor services that are widely used in macroeconomic labor market analyses.

Finally, as noted in section I, the specification given in (4) and (5) defines the effect of schooling quality on earnings solely as the effect of $Q$ on the slope coefficient, $\gamma_{b c}\left(\alpha_{b}+\alpha_{b c}\right.$ in the notation of the analysis of variance model presented in section I). This ignores the possible contribution of quality through the intercepts in the model, $\delta_{b c}$ and $\mu_{s c}$ (the $\theta$ components in our ANOVA decomposition). Focusing only on the effect of quality operating through $\gamma_{b c}$ may understate or overstate the contribution of quality to the level of wages.

The specifications considered by Card and Krueger ignore the effects of quality and other economic aggregates on the location of residence component to the return to education $\rho_{r c}\left(\alpha_{s c}\right.$ in our previous notation). We introduce such aggregates into the 
analysis and produce a richer economic model of the earnings function in the tradition of Tinbergen (1975) and Sattinger (1980). Of importance to the immediate discussion is our finding that quality aggregates often act like a supply shock and depress returns to skill. Measuring the effect of quality solely through $\gamma_{b c}\left(\alpha_{b}\right.$ or $\left.\alpha_{b}+\alpha_{b c}\right)$ generally overstates the contribution of quality to the total educational return.

Because there are components in the model which could plausibly be affected by schooling quality that are not considered in specification (4), evidence that $\varphi=0$ is not necessarily evidence that schooling quality does not affect earnings. Conversely, evidence that $\varphi \neq 0$ is not evidence that schooling quality raises earnings, because an offsetting reverse effect could operate through $\delta_{b c}$ or $\rho_{r c}$ In the next two sections, we shed light on this question by presenting empirical evidence of how quality affects earnings through the varion's channels just discussed.

\section{Replicating and Extending the Card-Krueger Model}

We have replicated Card and Krueger's study using both their schooling quality data (presented in Table 1 of their paper) and ours. The results of the two replications are similar, so we only present the results using our quality data. ${ }^{21}$ We use the ANOVA notation introduced in section $I$ to focus attention on the different components of the return to education that might be affected by schooling quality. Our current notation differs slightly, because some components of the model are stated in terms of region of residence and region of birth (denoted by $r(s)$ and $r(b)$ ) instead of state of residence and state of birth. For now, we consider the effect of quality operating through the slope parameters as do Card and Krueger. ${ }^{22}$ Later, we also examine the effects of quality on

21 We actually make a minor correction to Card and Krueger's model by including deviations around regional means in the second stage. Speakman and Welch (June, 1994) make the correct point that, in general, it is necessary to deviate the second stage regressors around regional intercepts to obtain consistent estimates of schooling quality's effect. One can show that Card and Krueger bias the evidence against themselves using their procedure, but the effects of correcting the adjustment are minor (see Heckman, Layne-Farrar, and Todd, 1995). The procedure Card and Krueger follow is correct only when migration by individuals is random. Random migration guarantees that regional means are national means, so taking deviations around regional means is not required.

22 After having determined through sensitivity analysis that Card and Krueger's model assuming linearity in education above the $2 \%$ yields very similar findings to a model assuming linearity in actual years of education, we decided to use the latter, more conventional modeling assumption. 
intercepts ( $\theta$ terms in (1)). In the ANOVA framework, the second stage regression model decomposing the total rate of return to education into cohort, state of birth, and region of residence components is given by:

(6) Total Rate of Return $\equiv \tilde{\alpha}_{r(s) b c}=\alpha+\alpha_{b}+\alpha_{c}+\alpha_{r(s)}+\alpha_{b c}+\alpha_{r(s) c}+\alpha_{r(s) r(b)}+\alpha_{r(s) b(s) c}$,

$\alpha_{c}$ allows for a cohort-specific mean, $\alpha_{b}$ and $\alpha_{b c}$ are the state of birth components, $\alpha_{r(s)}$ and $\alpha_{r(s) c}$ are the region of residence components, and $\alpha_{r(s) r(b)}$ and $\alpha_{r(s) r(b) c}$ are interactions between the state of birth, region of residence, and cohort. As noted in section I, the Card-Krueger model assumes the effect of quality operates solely through the state of birth components $\alpha_{b}$ and $\alpha_{b c}$ and suppresses region of birth-region of residence interaction terms $\left(\alpha_{r(s) r(b)}=0, \alpha_{r(s) r(b) c}=0\right)$. We initially maintain the assumption of no interaction effects but later relax it.

Table $7 \mathrm{a}$ presents results from our analysis of the 1980 Census. The specifications similar to the Card and Krueger model write $\alpha_{b c}$ and $\alpha_{b}$ as a function of quality (see columns one, two and three in Table 7a). Column one reports estimates of the effect of $\mathrm{Q}$, as measured by the pupil-teacher ratio, on $\alpha_{b c}$. We use the more interpretable pupilteacher ratio based on days attended rather than a measure based on days enrolled. The only difference between column one and two is the addition of two other quality measures--teacher salary and term length. The third specification is similar to the second, except that $\alpha_{b}$ is suppressed resulting in a single intercept term, rather than stateof-birth-specific intercepts. ${ }^{23}$

The coefficients in columns one through three are not identical to Card and Krueger's due our correction of taking deviations from region means instead of national means, our use of an attendance-based instead of an enrollment-based pupil-teacher ratio, our use of a different definition of teacher wages, and different standard errors. ${ }^{24}$

\footnotetext{
${ }^{23}$ The numbers in column 3 show the total effect of quality operating through both $\alpha_{b}$ and $\alpha_{b c}$. Columns 1 and 2 show the effect of quality operating through $\alpha_{b c}$ alone.

${ }^{24}$ We use Eicker-White robust standard errors in the second stage instead of estimating by GLS. This generally reduces the magnitude of the quality coefficients slightly, but the differences are not substantial.
} 
Despite these differences, our empirical results are very similar to theirs. ${ }^{25}$ Using days attended instead of enrolled weakens but does not eliminate the estimated impact of the pupil-teacher ratio on earnings. Deviating right-hand side variables around regional means also has only a slight effect on the estimated size and statistical significance of the coefficients.

In the first two columns, which include state of birth intercepts, the effect of quality is identified using variation in the rates of return for state of birth and cohort of birth removing cohort and state of birth means. The third column reports results from a model that suppresses the state of birth intercepts. This specification adds back the state of birth means and so identifies the effect of quality using variation in the rates of return for state of birth and cohort of birth removing only cohort of birth means. Contrary to the findings of Card and Krueger (1992b), the estimated effect is not robust to the exclusion of the state of birth intercepts intercepts: the third column shows the weakest results and frequently the sign on the pupil-teacher ratio reverses. However, if one wished to remove state of birth "fixed effects" from the estimated rate of return, then the estimates reported in the third column would be of no interest.

The results for 1970 and 1990 data may be found in Appendix C, tables $7 \mathrm{~b}$ and $7 \mathrm{c}$ respectively. ${ }^{26}$ For the first three columns which extend Card and Krueger's analysis to different data sets, the pattern found in the 1980 data of significant quality coefficients is upheld in the 1970 and 1990 data. The insignificance of the coefficient on the term length variable in 1970 is one exception. The quality effects estimated for 1990 are stronger (in absolute value terms) and are statistically more significant.

To aid in the interpretation of the estimated quality $\left(\mathrm{Q}_{\mathrm{bc}}\right)$ coefficients, Table 8 shows the effects of hypothetical improvements in schooling quality on earnings for two

\footnotetext{
An appendix showing comparable results using GLS estimation as well as results using the enrollment based pupil-teacher ratio is available from the authors upon request.

25 When we used Card and Krueger's exact model and quality data, we were able to replicate their estimated coefficients almost exactly.

26 We focus on the 1980 Census data in order to facilitate comparisons with Card and Krueger's results. Note that the 1970 sample contains an additional cohort as compared to samples from 1980 and 1990 . We include the 1940-49 cohort in the 1970 sample so that one cohort may be followed across all three Census years.
} 
education levels. No single quality variable emerges as the most important for affecting a change in earnings. The potential increases in earnings from changes in the relative teacher wage and term length are relatively larger in 1990. This pattern of amplification of estimated quality effects in 1990 is consistent with other evidence that the returns to schooling and ability have increased between 1980 and 1990. Contrary to claims in the literature, the effect of schooling inputs on earnings increased over the period 1980 to 1990 as the returns to education have increased. ${ }^{27}$

Table 8

Effect of Hypothetical Improvements in Quality on Earnings for High School Graduates and College Graduates

Model: Extension of Linear Model (coefficients given in tables 6a-c, column 2)

\begin{tabular}{|c|c|c|c|c|c|c|}
\hline \multirow[b]{2}{*}{ Change in Quality } & \multicolumn{2}{|c|}{1970} & \multicolumn{2}{|c|}{1980} & \multicolumn{2}{|c|}{1990} \\
\hline & $\begin{array}{c}12 \\
\text { years }\end{array}$ & $\begin{array}{c}16 \\
\text { years }\end{array}$ & $\begin{array}{c}12 \\
\text { years }\end{array}$ & $\begin{array}{c}16 \\
\text { years }\end{array}$ & $\begin{array}{c}12 \\
\text { years }\end{array}$ & $\begin{array}{c}16 \\
\text { years }\end{array}$ \\
\hline $\begin{array}{l}\text { Decrease pupil-teacher ratio } \\
\text { (attendance based measure) by } 5\end{array}$ & $\uparrow 5.33 \%$ & $\uparrow 7.12 \%$ & $\uparrow 3.76 \%$ & $\uparrow 5.01 \%$ & $\uparrow 6.40 \%$ & $\uparrow 8.53 \%$ \\
\hline $\begin{array}{l}\text { Increase relative teacher wage } \\
\text { by } 30 \%\end{array}$ & $\uparrow 4.32 \%$ & $\uparrow 5.76 \%$ & $\uparrow 7.49 \%$ & $\uparrow 9.98 \%$ & $\uparrow 9.32 \%$ & $\uparrow 12.4 \%$ \\
\hline Increase term length by 10 days & $\uparrow 0.89 \%$ & $\uparrow 1.18 \%$ & $\uparrow 1.28 \%$ & $\uparrow 1.71 \%$ & $\uparrow 7.74 \%$ & $\uparrow 10.3 \%$ \\
\hline
\end{tabular}

(1) Because returns are assumed to be linear in quality, the effects of other magnitudes of quality changes are easily found by rescaling the numbers in the table.

The remaining four columns in Table 7 extend the model beyond the original Card and Krueger specification. The model reported in column four differs from those in the previous columns by allowing each element of quality to have a cohort-specific effect. The estimates in this column thus indicate how measures of schooling quality affect returns to education for different cohorts. As Table 7 shows, for all Census years, estimated effects of the pupil-teacher ratio weaken or become perverse for more recent cohorts. This evidence supports the argument of diminishing variability in schooling quality in recent cohorts. Contrary to this argument, however, variability in term length

\footnotetext{
${ }^{27}$ Recall, though, that aggregate quality measures are virtually identical across the states by 1940 (see figures la and $b$ ). It is therefore important to distinguish between changes in the quality measures observed in the data and potential changes.
} 
has also declined considerably, but its estimated effect is strongest for more recent cohorts. ${ }^{28}$

The specifications reported in columns five and six investigate how regional aggregates of schooling quality affect the regional component of the return to education $\left(\alpha_{r(s)}\right.$ and $\left.\alpha_{r(s) \mathcal{c}}\right)$. Earnings functions are not solely determined by individual attributes but also depend on how the attributes are valued in the labor market. Therefore, we examine how the return to education is affected by variables that describe the local labor market, including the aggregate stocks of human capital. We allow the regional component of the educational return $\left(\alpha_{r(s)}\right.$ and $\alpha_{r(s) c}$ in equation (6)) to depend on regional demand and supply aggregates $Z$ :

$$
\begin{aligned}
& \alpha_{r(s) c}=Z_{r(s) c} \pi \\
& \alpha_{r(s)}=Z_{r(s) .} \pi
\end{aligned}
$$

It is through these channels that the first-order effects of economic aggregates should flow. The regional aggregates $(Z)$ considered are average schooling quality, education levels, and industrial composition.

In all three years, the estimates reported in columns five and six of Table 7 are consistent with a supply-shift hypothesis. When regional averages of the quality measures are added to the model, higher aggregate quality levels produce lower rates of return. ${ }^{29}$ In column 7 , we consider additional regional aggregates: the regional stocks of different levels of education and the percent of the workforce in manufacturing, interpreted as a demand shifter. In this specification, the coefficients on the quality variables are only partially consistent with a story that aggregates act like supply shifters; for example, average daily attendance has the wrong sign. The variables capturing the educational distribution of the workforce are highly statistically significant. Increases in the proportion of the labor force in the middle range of schooling (high school and 1-3 years of college) depress returns at the mean, while increases in dropouts raise the return at the mean. This is consistent with complementarity in production for inputs across

\footnotetext{
28 The coefficients in column 4 appear to be most strongly affected by the estimation method. GLS yields more significant quality coefficients than OLS with Eicker-White standard errors.

29 Recall that a positive coefficient on the pupil-teacher ratio means that as quality worsens, the rate of return rises.
} 
different skill groups. An increase in the proportion of workers near the educational mean depresses mean earnings. Except for 1980, increases in the percentage of the workforce in manufacturing reduce the returns to schooling (see tables $7 \mathrm{~b}$ and $7 \mathrm{c}$ in Appendix C).

Specifications five through seven also reveal that the estimated quality effects operating through $\alpha_{b c}$ are robust to the inclusion of regional aggregates in the model. The coefficients on individual quality measures are unchanged by the addition of the regional aggregates (compare to column 2).

Overall, these results show that we replicate Card and Krueger's general findings of significant quality effects with two additional Census years. Quality effects are especially strong in 1990 .

\section{The Effect of Quality Operating Through the Intercepts of the Card-Krueger Model}

The analysis of Johnson and Stafford (1973) models the effect of schooling quality operating through intercepts of the earnings equation rather than through slope parameters. $^{30}$ Quality has a uniform effect on log earnings regardless of the level of education, as is depicted in Figure 2(a). However, the nonparametric rank tests discussed in section II decisively reject a simple monotonic relationship between quality and earnings. Therefore, we do not replicate their model here.

Nevertheless, their findings motivate us to consider the effect of quality on the intercept parameters in Card and Krueger's model. This is an interesting exercise because it informs us how quality may operate through yet another channel - one explicitly ignored by Card and Krueger in an attempt to control for "fixed effects" bias arising from omitted state of birth and state of residence specific intercepts. In the ANOVA notation, the equation decomposing the model intercepts into the cohort, state of birth, and state of residence components is:

$$
\tilde{\theta}_{s b c}=\theta_{s}+\theta_{b}+\theta_{c}+\theta_{b c}+\theta_{s c}+\theta_{s b}+\theta_{s b c} .
$$

\footnotetext{
30 Johnson and Stafford (1973) test for both a slope and an intercept effect and find only the intercept effect to be significant, so they use an intercept model as their preferred specification.
} 
We maintain the assumption of their model that $\theta_{s b c}=\theta_{s b}=0$ and now estimate the effect of the empirical measures of schooling quality on $\theta_{b}, \theta_{b c}, \theta_{s}$, and $\theta_{s c}$.

In columns one through three of Tables 9a, the state of birth intercept terms are parameterized as functions of quality. This table contains results for the 1980 Census and analogous tables for 1970 and 1990 are found in Appendix C, Tables 9b-9c. The specifications given by each of the columns are analogous to those discussed in relation to the slope parameters. In our treatment of the intercept terms, we use state of residence instead of region of residence to index the current location variables. Most of the estimated coefficients on the quality variables are statistically significant. In Table $9 b$, for 1970, the pupil-teacher ratio operating through the intercepts supports the quality hypothesis and reinforces the slope effect seen earlier in Tables 7c. In 1980 and 1990, however, the effect of the pupil-teacher ratio operating through the intercept sometimes reinforces and sometimes counters the effect, depending on the model specification. For the term length and teacher salary variables, we find evidence that the effect of quality on earnings operates through the intercept parameters in a direction opposite to its effect through the slope coefficients for all three years. Hence, focusing only on an estimated quality effect operating through slope coefficients leads to an overstatement of the effect of the quality variables on earnings. Specification four, which allows the quality coefficients to differ across cohorts, generally supports these conclusions.

In columns five through seven, the state of residence intercepts are parameterized to be functions of regional aggregates. The signs of the regional average quality measures $\left(Q_{r(s)}\right)$ are affected by whether other regional aggregates are included in the model. They are not always consistent across Census years. The coefficients of the state of birth quality variables $\left(\mathrm{Q}_{b c}\right)$ are robust to the inclusion of these aggregates.

\section{Questioning Linearity}

Another critical assumption, and one that is standard throughout the literature, is the specification that log earnings equations are linear in years of education. ${ }^{31}$ This

\footnotetext{
31 An exception is a study by Wachtel (1976), in which the quality relationship is estimated separately by
} educational attainment level. 
assumption implies that the percentage earnings gain from a one year increase in schooling attainment is the same from ninth to tenth grade as it is from 3 to 4 years of college. The linear model does not allow for possible "sheepskin effects," which might be expected to occur upon completion of a high school or college degree. Furthermore, the linearity assumption imposes a severe limitation in the way quality is allowed to affect earnings. In the model given by equations (4) and (5), quality enters only interactively with education, imposing the restriction that a change in quality has a progressively larger effect at higher levels of educational attainment.

We test the linearity assumption by adding "sheepskin" effects (dummy variables for grade completion) at grades 8,12 , and 16 to equation (4). We then perform simple Ftests on the significance of the sheepskin effects, presented in Table 10.32 The data strongly reject linearity for most cohorts in the three Census samples and support the notion of sheepskin effects especially for post-secondary schooling. To illustrate the magnitude of the sheepskin coefficients, they are plotted for the 1980 Census, 1930-39 cohort in Figure 3. Because the Census sample sizes are rather large, there is a tendency to reject the null hypothesis of no sheepskin effects. We show the significance of the coefficients at the $0.1 \%$ significance level ("+" indicates significant at this level). There is clear evidence of discrete jumps in the return to education, especially for completion of a college degree. There is no support for the linearity hypothesis, a finding consistent with previous reported results in Solon and Hungerford (1987).

\section{A Nonlinear Model}

The data indicate that the return to additional years of education varies with the level of education, so we revise the earnings model to allow for nonlinearities in the log earnings equation. Given the evidence of especially significant sheepskin effects at the college level, we estimate a model that allows for discrete jumps in the return to education at 1-3 years of college and at 4 or more years of college. ${ }^{33}$ Thus, the model is

\footnotetext{
32 The F-tests are joint across all states of birth for each cohort at each level of schooling (8th and 12th grades and 4 years of college).

33 Since each additional education category adds 76-120 parameters to the model (depending on the specification), we did not introduce more than two marginal retums. Even though the nonlinear model is
} 
more flexible than the standard linear model. ${ }^{34}$ Since the samples we use are very large, it may be the case that the statistical rejections reported above are of little economic consequence. Linearity may not be grossly at odds with the data. Relaxing the linearity assumption would then have only a slight impact on estimates of the effect of quality on schooling - a hypothesis we test and reject below.

The nonlinear model can be written as:

$$
y_{i h s c}=\theta_{s h c}+\alpha_{r(s) b c}^{0} \cdot e_{i s h c}+\alpha_{r(s) b c}^{1} \cdot \tau_{i s h c}^{1}+\alpha_{r(s) b c}^{2} \cdot \tau_{i s h c}^{2}+X_{i h s c} \cdot \beta_{c}+\varepsilon_{i b s c}
$$

where

$$
\begin{aligned}
& \alpha_{r(s) b c}^{\prime}=\alpha_{c}^{j}+\alpha_{b}^{\prime}+\alpha_{r(s)}^{\prime}+\alpha_{b c}^{\prime}+\alpha_{r(s) c}^{\prime}, j=0,1,2 \\
& \theta_{s b c}=\theta_{c}+\theta_{b}+\theta_{b c}+\theta_{s}+\theta_{s c} \\
& \tau_{i s h c}^{\prime}= \begin{cases}1 & \text { if individual i completed some college but less than } 4 \text { years } \\
0 & \text { else }\end{cases} \\
& \tau_{i s b c}^{2}= \begin{cases}1 & \text { if individual i completed } 4 \text { or more years of college } \\
0 & \text { else }\end{cases}
\end{aligned}
$$

and where $e_{i s b c}$ is actual years of education. $X_{i s b c}$ represents the same demographic variables as used in the linear model (defined under equation (4)).

Since $\alpha_{r(s) b c}^{0}$ represents the per-year return to school, it is multiplied by the total number of years of education in order to obtain the total return to schooling for someone with a high school degree or less. For example, for someone with 13 years of school, the total return to education would be the linear effect plus the marginal effect, $\alpha_{r(s) b c}{ }^{*} 13+$

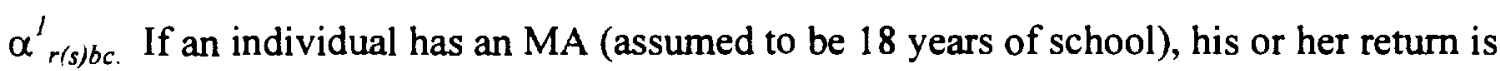
given by $\alpha_{r(s) b c}^{0}{ }^{*} 18+\alpha_{r(s) b c}^{2}$. To illustrate the magnitude of the estimated education returns for the model given in (8), Figure 4 plots them for a few representative states.

highly parameterized, our sample sizes are large (see Appendix A) and the coefficients are still precisely determined.

${ }^{34}$ Our model also improves over a model that assumes $2 \%$ linearity - constraining persons below the $2 \%$ threshold in the cohort of birth educational distribution to have the earnings of a person with no education (zero years of school up to the $2 \%$ cutoff are grouped together). Such a constraint is extreme for the later cohorts for whom the $2 \%$ threshold is as high as 9 years of school. 
To determine the effect of schooling quality on the rate of return to education, we parameterize the different components of the return as functions of the quality variables. Note that the second stage equation is estimated separately for the linear base return $\alpha_{r(s) b c}^{0}$ and for each of the marginal returns, $\alpha_{r(s) b c}^{l}$ and $\alpha_{r(s) b c}^{2}$. As with the linear model, we consider the effect of quality in the state of birth operating through the state of birth components, $\alpha_{b}^{j}$ and $\alpha_{b c}^{j}$ as well as the effect of aggregate quality on regional labor market conditions, operating through region of residence components, $c_{r(s)}^{j}$ and $\alpha_{r(s) c}^{j}$.

Tables 11.1(a) - 11.3(a) present the 1980 Census results obtained by estimating $\alpha_{r(s) b c}^{\prime}$ in equation (8) and using those estimates as the dependent variables in second stage regressions. The procedure we follow is analogous to that described for the linear case and the estimated coefficients can be compared to those in Tables 7(a). In specifications three through four of Table 11.1(a), which parameterize $\alpha_{b}^{j}$ and $\alpha_{b c}^{j}$ ar functions of quality, the signs of the quality coefficients are often reversed or else become statistically insignificant. Interestingly, support for an effect of secondary school quality on earnings comes through the marginal return for some college or for a college degree (see Tables 11.2(a), 11.3(a)). This finding is consistent with evidence reported by Wachtel (1976). As for the linear model, estimated quality effects differ in magnitude depending on whether or not fixed effects for state of birth are included in the model. The final three specifications examine the effect of quality operating through the regional return, $\alpha_{r(s)}^{j}$ and $\alpha_{r(s) c}^{j}$ Some statistically significant effects appear, but they are not interpretable because of many sign reversals.

The second stage regression results for 1970 and 1990 Census data are given in Appendix $C$ in tables 11.1(b)-11.3(b) and 11.1(c)-11.3(c). For 1970, there is some evidence of an effect of term length on the base return in specification (2), but the signs of the other estimated quality coefficients are generally inconsistent with the quality hypothesis. Support for an effect of quality on earnings again comes mainly through the marginal return to attending some college or to completing college. In 1990, the pupilteacher ratio is consistently of the expected sign only when the dependent variable is the marginal return to completing 4 or more years of college. 
Relaxing the false assumption of linearity yields models that provide little support for an effect of quality on earnings. The weak surviving support for the hypothesis is the estimated effect of quality on the marginal returns to college. It is likely that students from higher quality schools attend better colleges, in which case part of the estimated effect of secondary schooling quality is more properly attributable to college quality, a variable omitted from our regression.

To illustrate the effects of schooling quality on earnings implied by the estimated coefficients, we again tabulate the effects of counterfactual changes in quality in Table 12. The results are unstable across measures and years and do not provide strong support for the quality hypothesis.

Table 12

Effect of Hypothetical Improvements in Quality on Earnings Nonlinear Model incl. Region * Education Interactions (Coefficients in Tables 11.1-11.3, column 2)

\begin{tabular}{|c|c|c|c|c|c|c|}
\hline \multirow[b]{2}{*}{ Change in Quality } & \multicolumn{2}{|c|}{1970} & \multicolumn{2}{|c|}{1980} & \multicolumn{2}{|c|}{1990} \\
\hline & $\begin{array}{c}12 \\
\text { years }\end{array}$ & $\begin{array}{c}16 \\
\text { years }\end{array}$ & $\begin{array}{c}12 \\
\text { years }\end{array}$ & $\begin{array}{c}16 \\
\text { years }\end{array}$ & $\begin{array}{c}12 \\
\text { years }\end{array}$ & $\begin{array}{c}16 \\
\text { years }\end{array}$ \\
\hline $\begin{array}{l}\text { Decrease pupil-teacher ratio } \\
\text { (attendance based measure) by } 5\end{array}$ & $\downarrow 1.39 \%$ & $\uparrow 0.89 \%$ & $\uparrow 1.77 \%$ & $\uparrow 3.77 \%$ & $\downarrow 5.08 \%$ & $\downarrow 2.21 \%$ \\
\hline $\begin{array}{c}\text { Increase relative teacher wage } \\
\text { by } 30 \%\end{array}$ & $\uparrow 0.79 \%$ & $\uparrow 1.81 \%$ & $\uparrow 3.71 \%$ & $\uparrow 7.17 \%$ & $\uparrow 6.16 \%$ & $\uparrow 6.95 \%$ \\
\hline Increase term length by 10 days & $\uparrow 3.24 \%$ & $\uparrow 2.00 \%$ & $\downarrow 2.27 \%$ & $\downarrow 1.23 \%$ & $\uparrow 5.06 \%$ & $\uparrow 7.14 \%$ \\
\hline
\end{tabular}

\section{Accounting For Comparative Advantage By Region of Birth in Regions of Residence}

Section I and section III discussed the importance of random migration by individuals across states in securing identification of quality effects in aggregate data models. Section III provides evidence that individuals from particular states of residence tend to migrate to particular states of birth, presumably because of lower migration costs or higher expected gains. If their expected gains are correlated with realized values of the disturbance term in the earnings equation, $\varepsilon_{i b s c}$, then the disturbances are no longer 
exogenous with respect to the regressors and identification strategies such as the one pursued by Card and Krueger break down.

To allow for the possibility that individuals born in a certain states may have a comparative advantage in particular geographic regions, we relax the assumption that $\alpha_{r(s) r(b)}=0$ and $\alpha_{r(s) r(b) c}=0$ within the context of the linear model. F-tests of the assumption of no interactions, reported in Table 13 for each cohort in each Census year, decisively reject it. Therefore, we augment the model in (4) to include region of birth - region of residence interactions both in intercepts and in slope. In the notation from section $I$, the model is written as:

$$
\begin{aligned}
& y_{i s h c}=\tilde{\theta}_{s b c}+X_{i s h c} \cdot \tilde{\beta}_{c}+E_{i s b c} \cdot \tilde{\alpha}_{r(s) b c}+\varepsilon_{i s b c} \\
& \tilde{\theta}_{s h c}=\theta_{s}+\theta_{b}+\theta_{c}+\theta_{b c}+\theta_{s c}+\theta_{r(s) r(b)}+\theta_{r(s) r(b) c} \\
& \tilde{\alpha}_{r(s) b c}=\alpha_{r(s)}+\alpha_{b}+\alpha_{c}+\alpha_{b c}+\alpha_{r(s) c}+\alpha_{r(s) r(b)}+\alpha_{r(s) r(b) c} \\
& i=1, \ldots, I, \quad s=1, \ldots, S ; b=1, \ldots, B, c=1, \ldots, C, r=1, \ldots, R
\end{aligned}
$$

$\tilde{\beta}_{c}$ is constrained to be the same across states but is permitted to vary across cohorts. Interactions are introduced in terms of regions of birth and regions of residence $(r(s), r(b))$ instead of states of birth and states of residence.

The effect of quality 'n the return to education is estimated in two stages. First, estimates of the total return to education, $\tilde{\alpha}_{r(s) b c}$, are obtained for each $(b, s, c)$ cell from equation (9). In the second stage, components of the return to education are parameterized as functions of quality as before. In the most general treatment of the interaction terms $\left(\alpha_{r(s) b}, \alpha_{r(s) b c}\right)$, the quality effect operating through $\alpha_{b}$ and $\alpha_{b c}$ could be estimated without imposing restrictions on the interactions. This general model is difficult to interpret. However, when general interactions are introduced, most are statistically significant and estimated quality effects become statistically insignificant or 
perverse for both linear and nonlinear in education specifications. ${ }^{35}$ In this paper, we parameterize the interaction terms in a simple and interpretable way. We relax the assumption maintained in all the models considered thus far that the effect of a unit increase in schooling quality on the rate of return to education is the same across regions. We also allow the rate of return to education for individuals born in state $b$ living in region $r$ to depend on the physical distance between regions. Since longer distances traveled are usually associated with higher costs of migration (both actual and psychological costs), we would expect the rate of return to increase with the distance of the move. Formally, we write,

$$
\alpha_{r(s) b c}=\alpha_{b}+\alpha_{c}+\alpha_{r(s)}+\alpha_{r(s) c}+\varphi_{r(s)} Q_{b c}+\eta_{l} d_{r(s) r(b)}+\eta_{2} d_{r(b) r(s)}^{2}
$$

where $\varphi_{r}$ varies across regions and $d_{r(s) r(b)}$ is the distance between regions of birth and regions of residence. Card and Krueger assume that $\varphi_{r}=\varphi$ for all regions and ignore any effects of distance on returns to schooling. There is some evidence that the model in (10) is too simple (See Heckman et. al, 1995), but estimates obtained from it dramatically alter the evidence of how quality affects earnings, and more general, statistically significant, but less interpretable, interactions produce a pattern of estimated quality effects on earnings that strongly reject the schooling quality hypothesis.

Table 14a contains the estimated coefficients from the second stage model. These estimates are for a model with linear schooling. Results for a nonlinear schooling model are qualitatively similar (Heckman, Layne-Farrar and Todd, 1985). The specifications reported in the first three columns are for three different quality measures, taken one at a time, in a model that includes fixed effects for the state of birth. The effect of the pupilteacher ratio on the rate of return varies by region of residence. In most regions, a lower pupil-teacher ratio is associated with a higher rate of return to schooling, but this is not

\footnotetext{
${ }^{35}$ Heckman, Layne-Farrar, and Todd (1995) discuss the problem-common to all models with interactions of interpreting the meaning of non-zero interactions. Estimated quality effects may be non-robust to the choice of the reference state for measuring interactions. Our companion paper explores these issues and shows that for the data used in paper, the choice of a base state does not affect the qualitative conclusions of our analysis. Our companion paper estimates a fully-interacted model using the conventional base state - the mean across all effects.
} 
the case in New England. The coefficient on distance and its square is highly significant and in the expected direction in all specifications. Higher distance implies higher wages. As seen by columns (2) and (3), relative teacher salary has a similar effect on the rate of return across regions, but estimated effects of term length are always statistically insignificant or perversely signed. Columns (4) and (5) consider all three quality measures in specifications with and without fixed effects for state of birth, respectively. In our companion paper (Heckman et. al., 1995), we document that these results remain intact even when the distance variables are deleted. Permitting differential effects of quality on the returns to education across regions of residence is what produces the results reported here.

As was found in the previous models, estimated coefficients are not robust to the exclusion of these fixed effects. In column (5), the coefficient on pupil-teacher ratio is consistently of the wrong sign and the coefficient on teacher salary is diminished in magnitude and significance. The significant coefficients on term length are generally positive, but again the effect in New England runs counter to that in other regions.

Tables $14 \mathrm{~b}$ and $14 \mathrm{c}$ contain analogous results for the 1970 and 1990 Census years. In models with state of birth intercepts, the pupil-teacher ratio and teacher salary measures again show significant effects while the effect of term length is usually insignificant or in the wrong direction. The strongest effects for the first two quality variables are seen in the 1990 data. Excluding state of birth efferts (column (5)) generally leads to a reduction in the magnitude of the estimated pupil-teacher ratio and teacher salary effects, with some sign reversals for the pupil-teacher ratio in regions in 1970. The exclusion leads to an increase in the estimated effect of term length, which becomes strongly significant for most regions in 1990 .

Table 15 tests the restriction that the coefficients associated with the quality variables are identical across regions $\left(\varphi=\varphi_{r}\right)$ for all Census years. This assumption, maintained in all the models considered earlier and maintained in the previous literature, is rejected for the pupil-teacher ratio and term length but is not rejected for teacher salary. Therefore, unit increases in quality generally have different effects on the rate of return to 
schooling in different regions. This could arise because of differential region demand factors, or for other reasons previously discussed regarding comparative advantage and selective migration. Our evidence speaks against the crucial identifying assumptions used in previous studies. When relaxed, it challenges the story that schooling quality raises earnings. When the assumption of linearity of earnings in education is also relaxed, the evidence of any quality effect on earnings is further weakened. (Heckman et. al., 1995).

\section{The Effect of Schooling Quality on Educational Attainment Levels}

In the introduction, we identify three ways that schooling quality can affect earnings. Thus far, we have only considered the first two: the effect of schooling quality on the intercepts and the effect of quality on the slopes of the earnings-schooling relationship, holding constant the level of educational attainment. We now consider a third: its role in increasing the incentive for students to further their education. Students attending higher quality secondary schools may be more likely to graduate from high school or more likely to go to college. This relationship has been found in several previous studies. ${ }^{36}$

To examine the impact of schooling quality on years of education completed, we estimate the relationship between the proportions of college graduates, high school graduates without postsecondary degrees, and high school dropouts in each state and our quality indicators:

$$
\ln \left[N_{\text {Ed Level(b,c) }} / \text { Population }_{b c}\right]=\alpha_{c}+\ln \left[Q_{b c}\right] \cdot \beta_{c}
$$

As before, $c$ designates the cohort and $b$ the state of birth. The variable $N_{E d \text {. level (b,c) }}$ is the total number of individuals born in state $b$ in cohort $c$ with a specific level of education. Dividing by the total number of individuals born in state $b$ in cohort $c$ gives the proportion of the population with that education level. The three education levels

\footnotetext{
${ }^{36}$ Both Card and Krueger (1992a) and Johnson and Stafford (1973) find evidence for such an effect.
} 
considered are college graduation, high school graduation (without college degree), and high school dropout.

The proportions of different education levels show considerable variation across states and over time. The region with the lowest percentage of college graduates is East South Central, consisting of Alabama, Kentucky, and Tennessee. In 1970 data, only 8\% of the 1910-19 cohort born in that region had received a college degree or higher. Fully $59 \%$ of them were high school dropouts. These figures improve somewhat over time, but educational attainment is the lowest here among the nine regions: in the 1990 data, $22 \%$ of the 1950-59 cohort had graduated college and only $14 \%$ were high school dropouts. The Pacific region, with California, Oregon, and Washington, and the Mid-Atlantic region, with New York, New Jersey, and Pennsylvania produce the highest percentages of college graduates. Around 15\% of the 1910-19 cohort born in these regions have college degrees according to 1970 Census data. This number increases to $28 \%$ for the Pacific region and 35\% for the Mid-Atlantic region for the 1950-59 cohort in 1990 Census data.

We estimate equation (11) by regressing the proportion of college graduates in each state, by cohort, on our four quality measures. Table $17 \mathrm{a}$ displays the coefficient estimates for the 1980 Census (17b and 17c, in Appendix C, show the results from the 1970 and 1990 data, respectively). The proportion of college graduates, shown in the top panel, is consistently positively related to all of the schooling quality indices for all cohorts. Because the relationship is expressed as a log-log model, we can interpret the quality coefficients as the percent change in the proportion of college graduates resulting from a $1 \%$ change in quality. For example, if average classroom size decreased by $1 \%$ for the 1920-29 cohort, we would expect a $.42 \%$ increase in the proportion of college graduates. The model for the proportion of high school graduates, presented in the middle panel, shows a weaker relationship. While the estimated coefficients have the expected signs, they are often statistically insignificant. The last panel, however, which regresses the proportion of high school dropout on quality, st.uws strong results. Increasing schooling quality decreases the proportion of dropouts. The results for 1970 and 1990 are analogous. 
This evidence provides some support for the hypothesis of a positive effect of schooling quality on schooling attainment previously found in the literature. It is interesting to note that the same pattern found in the quality-earnings regressions is found here as well: the weakest link between secondary school quality and outcomes is for high school graduates. The connection is much stronger for college graduates and high school dropouts.

While the relationship is robust across Census years it may be spurious for reasons that Card and Krueger enunciate in their discussion of earlier studies of the earnings-quality relationship: estimated quality effects are confounded with family background and state of residence effects on the schooling decision. Differences across states in educational attainment levels could be due, in part, to differences in family backgrounds or to different local labor market conditions. The strategy of using worker mobility to identify quality effects on earnings cannot be applied to estimate the qualityeducational attainment relationship, because there are no comparable mobility data on students across school systems.

\section{Conclusions}

\section{Summary}

This paper examines the empirical and conceptual foundations of recent studies designed to estimate the impact of schooling quality on earnings. In it, we set forth a general analysis of variance framework within which we nest previous models. We make explicit the identifying assumptions and definitions of the quality effect of interest implicit in previous studies. We also estimate more general models and test restrictions imposed in previous studies.

We reach the following main conclusions about the existing evidence on whether measured quality affects earnings.

(1) Aggregate estimation approaches secure identification of quality effects by comparing the earnings of people living in the same labor market but born (and presumably educated) in different states. This strategy breaks down when individuals migrate selectively on the basis of expected earnings in the destination region and there is 
some relationship between their expectations and the unobservables in destination earnings equations. Evidence on nonrandom sorting by region of residence and region of birth and evidence on the higher wages of the migrant population point to the empirical importance of selective migration.

(2) The leading models in the literature predict that quality and earnings are monotonically related. This can be tested nonparametrically. Nonparametric rank tests comparing state of birth rankings by quality with rankings by wages suggest no relationship between the empirical measures of schooling quality and wages. Earnings ranks by state of birth show some stability across regions of residence, but the sources of stability are unrelated to the aggregate measures of quality. Our evidence on the stability of ranks of state of birth in wage distributions across regions of residence is consistent with many other stories besides ones that emphasize schooling quality. For example, a story that emphasizes the importance of family background on raising earnings can also account for this evidence.

(3) Empirical studies in the literature differ in their parameters of interest and in their assumed functional forms for the earnings equation. Imposing the identifying assumptions of the Card-Krueger model, we find that their analysis can be replicated in 1970 and 1990 . Within their framework, there is evidence for a quality effect and it is the strongest in 1990. We also find significant effects of aggregate measures of quality and aggregate supply and demand variables on the regional return to education.

(4) Extending the analysis of Card and Krueger to estimate the effect of quality operating through intercepts, we find evidence that quality operates not only through slope parameters but also through model intercepts. Quality lowers intercepts, so empirical studies that focus solely on slopes may overstate the total effect of quality on earnings.

(5) The assumption that log earnings and education are linearly related is decisively rejected by the data. Insteau, there are nonlinearities in the return to education associated with significant sheepskin effects, particularly at the college level. In an earnings model that relaxes linearity, support of the quality hypothesis weakens considerably. The only 
evidence for a positive relationship between schooling quality and earnings is among those who attend college.

(6) Estimated quality effects are sensitive to changes in model specification to allow for selective migration and region of birth-region of residence interactions in earnings equations. Allowing for differential effects of quality across regions, we find that the effect of the pupil-teacher ratio on the rate of return to education differs across labor markets and that term length has little or no effect on the return to schooling. However, there is some support in this model for a positive effect of relative teacher salary that is uniform across labor markets. This support vanishes, however, when statisticallysignificant region of birth-region of residence interactions for an unrestricted model are introduced. (Heckman, Layne-Farrar and Todd, 1995).

\section{Have We Settled the Debate?}

The evidence in this paper, like the evidence in the literature that precedes it, is not decisive on the question of whether schooling inputs can raise earnings. All we have done is raise doubts about the quality of the evidence about quality, based on aggregated data.

The available measures of schooling quality are crude. Estimating equations used in the literature do not capture explicit choice mechanisms for parents and school authorities or the detailed schooling production processes required to justify specific policy interventions. As Hanushek (1991) notes, the absence of a strong empirical relationship between measured outcomes and measured inputs may reflect the quality of the measures and the inefficiency of most schooling organizations in transforming inputs to outputs.

This paper like the ones that precede it, takes as exogenously given the quality of schooling in a person's state of birth. Until the mechanism of quality determination is understood, and the statistical consequences of the mechanism are understood, any evidence about quality-earnings effects is at best tentative. 


\section{References}

Behrman, Jere R., and Birdsall, Nancy. "The Quality of Schooling: Quantity Alone Is Misleading." A.E.R., 73 (December 1983): 928-46.

Betts, Julian. "Does School Quality Matter? Evidence from the National Longitudinal Survey of Youth." Unpublished paper, University of California, San Diego (1993).

, "Is There a Link Between School Inputs and Earnings? Fresh Scrutiny of an Old Literature," forthcoming in G. Burtless, ed. Does Money Matter? The Link Between Schools, Student Achievement and Adult Success, Brookings Institution, Washington, D.C. (1995).

Card, David and Krueger, Alan. "School Quality and Black-White Relative Earnings: A Direct Assessment." Quarterly Journal of Economics, 107 (February 1992a).

, "Does School Quality Matter: Returns to Education and the Characteristics of Public Schools in the United States." Journal of Political Economy, 100, No. 1, (1992b): 1-40.

, "The Economic Return to School Quality: A Partial Survey." Unpublished working paper, Princeton University (1994).

Coleman, James S., et.al. Equality of Educational Opportunity. Washington: Government Printing Office (1966).

Hamilton, Horace. "Educational Selectivity of Net Migration From the South." Social Forces, Vol. 38 (1959/1960): 33-42.

Hanushek, Eric. "The Economics of Schooling: Production and Efficiency in Public Schools." Journal of Economic Literature, 24 (1986):1141-1177.

, "The Impact of Differential Expenditures on School Performance," Educational Researcher, 18 (1989): 45-65.

, "When School Finance 'Reform' May Not Be Good Policy", Harvard Journal of Legislation, Vol. 28 (June 1991): 423-464.

$\overline{(1994)}$.

“et. al., "Aggregation Bias," Unpublished manuscript, University of Rochester,

and Ralph W. Harbison. Educational Performance of the Poor: Lessons from Rural Northeast Brazil, Oxford University Press for the World Bank (1992). 
Heckman, James, Anne Layne-Farrar and Petra Todd. "The Schooling Quality-Earnings Relationship: Using Economic Theory to Interpret Functional Forms Consistent with the Evidence," Under review at Review of Economics and Statistics.

and Derek Neal. "James Coleman's Contributions to Education: An Intellectual Odyssey", forthcoming in James S. Coleman: Falmer Sociology Series, London-New York-Philadelphia, Falmer Press (1996).

and Richard Robb. "Evaluating The Impact of Interventions on Outcomes", in J. Heckman and B. Singer, eds., Longitudinal Analysis of Labor Market Data, Cambridge, England, Cambridge University Press (1985).

and G. Sedlacek. "Heterogeneity, Aggregation and Market Wage Functions", Journal of Political Economy (December 1985): 1123-1148.

and Sheinkman, J. "The Importance of Bundling in a Gorman-Lancaster Model of Earnings," Review of Economic Studies, 1987.

Hedges, Larry V., Richard D. Laine and Rob Greenwald. "Does Money Matter? A Metaanalysis of Studies of the Effects of Differential School Inputs on Student Outcomes." Educational Researcher, 23, No. 3 (April 1994): 514.

Johnson, George E., and Frank P. Stafford. "Social Returns to Quantity and Quality of Schooling." Journal of Human Resources, 8 (Spring 1973): 139-55.

Mincer, Jacob. Schooling, Experience and Earnings, New York, National Bureau of Economic Research, 1974.

Morgan, James and Ismail Sirageldin. "A Note on the Quality Dimension in Education." Journal of Political Economy, 76 (September/October 1968): 1069-1077.

Rizzuto, Ronald, and Paul Wachtel. "Further Evidence on the Returns to School Quality", Journal of Human Resources, 15 (Spring 1980): 240-54.

Rosen, Sherwin. "A Note on Aggregation of Skills and Labor Quality", Journal of Human Resources, 18 (1983): 425-431.

Sattinger, Michael. Capital and The Distribution of Labor Earnings, North Holland (1980).

Sjaastad,Larry A. "The Costs and Returns of Human Migration," Journal of Political Economy, 1962.

Solon, Gary and Thomas Hungerford. "Sheepskin Effects In The Returns To Education", Review Economics and Statistics, 69 (February 1987): 175-177. 
Speakman, Robert and Finis Welch. "Micro and Macro Estimates of The Value of School Resources”, unpublished manuscript, Texas A.\& M (June, 1994).

Tinbergen, Jan. Income Distribution: Analysis and Policies: Amsterdam (1975). "Income Distribution: Second Thoughts", De Economist, 125 (1977): 315-339.

Wachtel, Paul. "The Effects on Earnings of School and College Investment Expenditures. "Review of Economics and Statistics, 58 (August 1976): 326-31.

Welch, Finis. "Measurement of the Quality of Schooling." American Economic Review Papers and Procedings, 56 (May 1966): 379-92.

"Labor-Market Discrimination: An Interpretation of Income Differences in the Rural South." Journal of Political Economy, 75 (June 1967): 225-40.

White, Halbert. "A Heteroskedasticity Consistent Covariance Matrix and a Direct Test for Heteroskedasticity," Econometrica, 48, (1980): 817-838. 
TABLE 2

Evidence on the Increased A verage Educational Quality and Wages of State-to-State Migrants verses Non-Migrants

\begin{tabular}{|c|c|c|c|c|c|c|c|c|c|c|c|}
\hline \multirow[b]{3}{*}{$\begin{array}{l}\text { Census } \\
\text { Year }\end{array}$} & \multirow{3}{*}{$\begin{array}{l}\begin{array}{l}\text { Birth } \\
\text { Cohort: }\end{array} \\
\text { Education } \\
\text { Level } \\
\end{array}$} & \multicolumn{10}{|c|}{$\begin{array}{l}\text { Proportion of States for which the Average Educational Quality or A verage Weekly Wage of Migrants } \\
\text { Exceeds that of Non-Migrants }\end{array}$} \\
\hline & & \multicolumn{2}{|c|}{$1910-19$} & \multicolumn{2}{|c|}{ 1920-29 } & \multicolumn{2}{|c|}{$1930-39$} & \multicolumn{2}{|c|}{$19 \overline{1940-49}$} & \multicolumn{2}{|c|}{$1950-59$} \\
\hline & & PT ratio & $\begin{array}{l}\text { weekly } \\
\text { wage }\end{array}$ & PT raio & $\begin{array}{c}\text { weekly } \\
\text { wage }\end{array}$ & PT ratio & $\begin{array}{l}\text { weekly } \\
\text { wage }\end{array}$ & PT ratio & $\begin{array}{c}\text { weekly } \\
\text { wage }\end{array}$ & PT ratio & $\begin{array}{l}\text { weekly } \\
\text { wage }\end{array}$ \\
\hline \multirow[t]{4}{*}{1970} & $<12$ th grade & .55 & .88 & .59 & .86 & .65 & .59 & .64 & .53 & $\ldots$ & $\ldots$ \\
\hline & 12th grade & .53 & .82 & .59 & .92 & .59 & .84 & 63 & .39 & $\ldots$ & $\ldots$ \\
\hline & $1-3$ college & .51 & .78 & .61 & .84 & .57 & .80 & .55 & .39 & $\ldots$ & $\ldots$ \\
\hline & $4+$ college & .47 & .84 & .49 & .83 & .51 & .86 & .53 & .45 & $\ldots$ & $\ldots$ \\
\hline \multirow[t]{4}{*}{1980} & $<12$ th grade & $\ldots$ & $\ldots$ & .59 & .88 & .61 & .88 & .59 & .75 & $\ldots$ & $\ldots$ \\
\hline & 12th grade & ... & $\ldots$ & .57 & .80 & .55 & .90 & .55 & .57 & $\ldots$ & $\ldots$ \\
\hline & 1-3 college & $\ldots$ & ... & .57 & .80 & .57 & .76 & .47 & .65 & $\ldots$ & $\ldots$ \\
\hline & $4+$ college & ... & $\ldots$ & .55 & .92 & .49 & .90 & .47 & .96 & $\cdots$ & $\cdots$ \\
\hline \multirow[t]{4}{*}{1990} & $<12$ th grade & $\ldots$ & $\ldots$ & $\ldots$ & $\ldots$ & .67 & .65 & .57 & .67 & .53 & .98 \\
\hline & 12th grade & ... & $\ldots$ & ... & ... & .59 & .78 & .55 & .76 & .49 & .61 \\
\hline & $1-3$ college & $\ldots$ & $\ldots$ & $\ldots$ & $\ldots$ & .59 & .82 & .51 & .82 & .49 & .61 \\
\hline & $4+$ college & $\ldots$ & $\ldots$ & $\ldots$ & $\ldots$ & .49 & .92 & .47 & .96 & .46 & .98 \\
\hline
\end{tabular}

(1) "PT ratio" refers to the pupil-teacher ratio based on days enrolled. See Appendix B for detailed discussion of the schooling quality data.

(2) The samples used to calculate the numbers in this table are described in Appendix A. 


\begin{tabular}{|c|c|c|c|c|c|c|c|c|c|}
\hline \multicolumn{10}{|c|}{$\begin{array}{c}\text { Table } 3 \\
\text { Distribution of Regional Migration } \\
1980 \text { Census, Cohort 1930-39, < 12th grade }\end{array}$} \\
\hline \multirow[b]{2}{*}{ Region of Birth } & \multicolumn{9}{|c|}{ Region of Residence } \\
\hline & NE & MA & ENC & WNC & SA & ESC & WSC & Mtn & Pac \\
\hline Northeast & 83.97 & 3.11 & 1.40 & 0.39 & 5.20 & 0.23 & 0.91 & 1.09 & 3.70 \\
\hline Middle Atlantic & 1.47 & 83.57 & 3.29 & 0.38 & 5.80 & 0.43 & 0.89 & 1.33 & 2.85 \\
\hline East North Central & 0.32 & 1.01 & 83.96 & 2.05 & 3.64 & 1.39 & 1.41 & 2.02 & 4.20 \\
\hline West North Central & 0.21 & 0.45 & 6.73 & 68.15 & 1.57 & 0.54 & 3.25 & 6.40 & 12.69 \\
\hline South Atlantic & 0.32 & 1.92 & 7.87 & 0.39 & 83.81 & 2.02 & 1.46 & 0.69 & 1.53 \\
\hline East South Central & 0.12 & 0.57 & 22.73 & 0.82 & 7.96 & 61.70 & 3.30 & 0.85 & 1.96 \\
\hline West South Central & 0.14 & 0.21 & 3.67 & 3.52 & 1.49 & 1.46 & 74.52 & 3.81 & 11.17 \\
\hline Mountain & 0.16 & 0.60 & 2.03 & 2.96 & 1.87 & 0.38 & 3.68 & 62.90 & 25.41 \\
\hline Pacific & 0.47 & 0.67 & 1.14 & 1.04 & 2.28 & 0.47 & 2.28 & 5.44 & 86.21 \\
\hline \multicolumn{10}{|c|}{1980 Census, Cohort 1930-39, 12th grade } \\
\hline & \multicolumn{9}{|c|}{ Region of Residence } \\
\hline Region of Birth & NE & MA & ENC & WNC & SA & ESC & WSC & Mtn & Pac \\
\hline Northeast & 79.08 & 3.42 & 1.72 & 0.75 & 6.37 & 0.73 & 1.50 & 1.86 & 4.55 \\
\hline Middle Atlantic & 2.16 & 77.88 & 4.07 & 0.50 & 8.19 & 0.52 & 1.28 & 1.69 & 3.73 \\
\hline East North Central & 0.46 & 1.17 & 80.26 & 2.54 & 4.62 & 1.30 & 1.88 & 2.60 & 5.18 \\
\hline West North Central & 0.34 & 0.62 & 6.16 & 65.17 & 2.50 & 0.90 & 3.89 & 6.83 & 13.58 \\
\hline South Atlantic & 0.49 & 2.19 & 6.03 & 0.76 & 81.04 & 2.83 & 2.43 & 1.45 & 2.78 \\
\hline East South Central & 0.31 & 0.61 & 14.54 & 1.39 & 11.22 & 62.87 & 4.66 & 1.30 & 3.10 \\
\hline West South Central & 0.16 & 0.46 & 2.43 & 3.32 & 2.68 & 1.85 & 73.42 & 4.39 & 11.30 \\
\hline Mountain & 0.38 & 0.95 & 2.25 & 2.85 & 1.95 & 0.70 & 3.88 & 63.11 & 23.92 \\
\hline Pacific & 0.29 & 0.53 & 1.18 & 1.37 & 2.51 & 0.53 & 1.86 & 6.21 & 85.52 \\
\hline \multicolumn{10}{|c|}{1980 Census, Cohort 1930-39, 1-3 years college } \\
\hline & \multicolumn{9}{|c|}{ Region of Residence } \\
\hline Region of Birth & NE & MA & ENC & WNC & SA & ESC & WSC & Mtn & Pac \\
\hline Northeast & 68.03 & 5.43 & 2.17 & 0.36 & 9.26 & 0.87 & 2.26 & 2.44 & 9.17 \\
\hline Middle Atlantic & 3.50 & 63.55 & 4.75 & 0.99 & 11.74 & 0.84 & 2.46 & 2.92 & 9.24 \\
\hline East North Central & 0.88 & 1.85 & 66.21 & 3.03 & 6.86 & 1.64 & 3.38 & 4.41 & 11.73 \\
\hline West North Central & 0.66 & 1.25 & 7.03 & 48.34 & 3.96 & 1.52 & 6.35 & 9.05 & 21.84 \\
\hline South Atlantic & 0.62 & 2.40 & 4.39 & 0.74 & 76.34 & 3.86 & 3.81 & 2.49 & 5.35 \\
\hline East South Central & 0.56 & 1.39 & 10.47 & 1.33 & 15.32 & 54.75 & 7.51 & 2.37 & 6.30 \\
\hline West South Central & 0.42 & 0.62 & 2.27 & 2.72 & 3.88 & 2.83 & 67.60 & 5.41 & 14.25 \\
\hline Mountain & 0.58 & 0.49 & 2.60 & 2.73 & 2.33 & 0.58 & 4.03 & 56.16 & 30.50 \\
\hline Pacific & 0.33 & 0.76 & 1.04 & 1.09 & 2.37 & 0.33 & 2.09 & 6.65 & 85.32 \\
\hline \multicolumn{10}{|c|}{1980 Census, Cohort 1930-39, 4+ years college } \\
\hline & & & & & on of $R$ & idence & & & \\
\hline Region of Birth & NE & MA & ENC & WNC & $\mathbf{S A}$ & ESC & WSC & Mtn & Pac \\
\hline Northeast & 58.27 & 11.52 & 4.69 & 1.25 & 11.03 & 0.84 & 2.25 & 2.11 & 8.03 \\
\hline Middle Atlantic & 6.27 & 57.50 & 6.71 & 1.41 & 13.81 & 1.06 & 2.41 & 2.15 & 8.68 \\
\hline East North Central & 2.16 & 4.96 & 56.82 & 4.61 & 9.46 & 2.01 & 3.94 & 3.87 & 12.17 \\
\hline West North Central & 1.50 & 3.14 & 10.60 & 44.15 & 6.50 & 1.27 & 6.70 & 8.31 & 17.84 \\
\hline South Atlantic & 1.71 & 5.43 & 5.45 & 1.41 & 70.01 & 4.72 & 3.69 & 1.92 & 5.64 \\
\hline East South Central & 0.60 & 2.36 & 7.77 & 2.10 & 20.10 & 51.49 & 7.97 & 2.12 & 5.49 \\
\hline West South Central & 0.82 & 1.59 & 3.23 & 3.88 & 6.24 & 3.47 & 64.79 & 5.68 & 10.32 \\
\hline Mountain & 1.23 & 2.21 & 4.01 & 4.26 & 5.43 & 1.04 & 5.21 & 47.49 & 29.11 \\
\hline Pacific & 1.39 & 2.06 & 2.66 & 1.63 & 4.74 & 0.89 & 2.42 & 5.93 & 78.30 \\
\hline
\end{tabular}

This table shows the regional migration patterns for the samples of white males described in Appendix A. 
TABLE 4(a)

Kendall Tau Correlations between Region of Birth Quality and Log Wage Rankings* 1980 Census, Individuals with 12 Years Education

Correlations done separately within the nine regions of residence. P-values given in parentheses. ${ }^{(1)}$

\begin{tabular}{|c|c|c|c|c|c|c|c|c|c|c|}
\hline & & \multicolumn{9}{|c|}{ Region of Residence } \\
\hline & & $\mathrm{NE}$ & MA & ENC & WNC & SA & ESC & WSC & Mt. & Pac. \\
\hline \multirow[t]{4}{*}{$1920-29$} & PTR-E & $\begin{array}{l}-0.50 \\
(0.06)\end{array}$ & $\begin{array}{l}-0.17 \\
(0.53)\end{array}$ & $\begin{array}{l}0.06 \\
(0.83)\end{array}$ & $\begin{array}{l}0.28 \\
(0.30)\end{array}$ & $\begin{array}{l}-0.06 \\
(0.83)\end{array}$ & $\begin{array}{l}-0.33 \\
(0.21)\end{array}$ & $\begin{array}{l}0.06 \\
(0.83)\end{array}$ & $\begin{array}{l}-0.50 \\
(0.06)\end{array}$ & $\begin{array}{l}0.22 \\
(0.40)\end{array}$ \\
\hline & PTR-A & $\begin{array}{l}-0.17 \\
(0.53)\end{array}$ & $\begin{array}{l}0.06 \\
(0.83)\end{array}$ & $\begin{array}{l}-0.06 \\
(0.83)\end{array}$ & $\begin{array}{l}0.39 \\
(0.14)\end{array}$ & $\begin{array}{c}-0.50 \\
(0.06)\end{array}$ & $\begin{array}{c}-0.11 \\
(0.68)\end{array}$ & $\begin{array}{l}-0.06 \\
(0.83)\end{array}$ & $\begin{array}{c}-0.50 \\
(0.06)\end{array}$ & $\begin{array}{l}0.00 \\
(1.00)\end{array}$ \\
\hline & Teacher salary & $\begin{array}{l}0.09 \\
(0.75)\end{array}$ & $\begin{array}{l}-0.03 \\
(0.91)\end{array}$ & $\begin{array}{l}0.02 \\
(0.91)\end{array}$ & $\begin{array}{l}-0.33 \\
(0.24)\end{array}$ & $\begin{array}{l}0.75 \\
(0.01)\end{array}$ & $\begin{array}{l}-0.21 \\
(0.45)\end{array}$ & $\begin{array}{l}0.15 \\
(0.59)\end{array}$ & $\begin{array}{l}0.09 \\
(0.75)\end{array}$ & $\begin{array}{l}0.27 \\
(0.33)\end{array}$ \\
\hline & Term length & $\begin{array}{l}0.44 \\
(0.09)\end{array}$ & $\begin{array}{l}-0.11 \\
(0.68)\end{array}$ & $\begin{array}{l}-0.22 \\
(0.40)\end{array}$ & $\begin{array}{l}0.22 \\
(0.40)\end{array}$ & $\begin{array}{c}-0.22 \\
(0.40)\end{array}$ & $\begin{array}{l}0.28 \\
(0.30)\end{array}$ & $\begin{array}{l}0.00 \\
(1.00)\end{array}$ & $\begin{array}{l}0.00 \\
(1.00)\end{array}$ & $\begin{array}{l}-0.39 \\
(0.14)\end{array}$ \\
\hline \multirow[t]{4}{*}{$1930-39$} & PTR-E & $\begin{array}{l}-0.44 \\
(0.10)\end{array}$ & $\begin{array}{l}0.00 \\
(1.00)\end{array}$ & $\begin{array}{l}-0.22 \\
(0.40)\end{array}$ & $\begin{array}{l}0.28 \\
(0.30)\end{array}$ & $\begin{array}{l}0.17 \\
(0.53)\end{array}$ & $\begin{array}{l}0.11 \\
(0.68)\end{array}$ & $\begin{array}{l}0.22 \\
(0.40)\end{array}$ & $\begin{array}{l}0.06 \\
(0.83)\end{array}$ & $\begin{array}{c}-0.11 \\
(0.68)\end{array}$ \\
\hline & PTR-A & $\begin{array}{l}-0.39 \\
(0.14)\end{array}$ & $\begin{array}{l}0.17 \\
(0.53)\end{array}$ & $\begin{array}{l}-0.39 \\
(0.14)\end{array}$ & $\begin{array}{l}0.33 \\
(0.21)\end{array}$ & $\begin{array}{l}0.22 \\
(0.40)\end{array}$ & $\begin{array}{l}-0.06 \\
(0.83)\end{array}$ & $\begin{array}{l}0.28 \\
(0.30)\end{array}$ & $\begin{array}{l}-0.11 \\
(0.68)\end{array}$ & $\begin{array}{l}-0.06 \\
(0.83)\end{array}$ \\
\hline & Teacher salary & $\begin{array}{l}-0.47 \\
(0.10)\end{array}$ & $\begin{array}{l}0.03 \\
(0.90)\end{array}$ & $\begin{array}{l}-0.55 \\
(0.06)\end{array}$ & $\begin{array}{l}-0.11 \\
(0.71)\end{array}$ & $\begin{array}{l}0.18 \\
(0.53)\end{array}$ & $\begin{array}{l}0.04 \\
(0.90)\end{array}$ & $\begin{array}{l}-0.04 \\
(0.90)\end{array}$ & $\begin{array}{l}-0.04 \\
(0.90)\end{array}$ & $\begin{array}{c}-0.04 \\
(0.90)\end{array}$ \\
\hline & Term length & $\begin{array}{l}0.33 \\
(0.21)\end{array}$ & $\begin{array}{l}-0.22 \\
(0.40)\end{array}$ & $\begin{array}{l}0.00 \\
(1.00)\end{array}$ & $\begin{array}{l}-0.28 \\
0.30\end{array}$ & $\begin{array}{l}-0.17 \\
(0.53)\end{array}$ & $\begin{array}{l}-0.11 \\
(0.68)\end{array}$ & $\begin{array}{l}-0.11 \\
(0.68)\end{array}$ & $\begin{array}{l}-0.17 \\
(0.53)\end{array}$ & $\begin{array}{l}-0.11 \\
(0.68)\end{array}$ \\
\hline \multirow[t]{4}{*}{$1940-49$} & PTR-E & $\begin{array}{l}-0.61 \\
(0.02)\end{array}$ & $\begin{array}{l}0.00 \\
(1.00)\end{array}$ & $\begin{array}{l}0.06 \\
(0.83)\end{array}$ & $\begin{array}{l}0.00 \\
(1.00)\end{array}$ & $\begin{array}{l}0.06 \\
(0.83)\end{array}$ & $\begin{array}{l}0.39 \\
(0.14)\end{array}$ & $\begin{array}{l}0.17 \\
(0.53)\end{array}$ & $\begin{array}{l}-0.17 \\
(0.53)\end{array}$ & $\begin{array}{l}0.00 \\
(1.00)\end{array}$ \\
\hline & PTR-A & $\begin{array}{l}-0.61 \\
(0.02)\end{array}$ & $\begin{array}{l}-0.11 \\
(0.68)\end{array}$ & $\begin{array}{l}-0.06 \\
(0.83)\end{array}$ & $\begin{array}{l}0.11 \\
(0.68)\end{array}$ & $\begin{array}{l}-0.06 \\
(0.83)\end{array}$ & $\begin{array}{l}0.28 \\
(0.30)\end{array}$ & $\begin{array}{l}0.28 \\
(0.30)\end{array}$ & $\begin{array}{c}-0.17 \\
(0.53)\end{array}$ & $\begin{array}{l}0.00 \\
(1.00)\end{array}$ \\
\hline & Teacher salary & $\begin{array}{l}-0.15 \\
(0.59)\end{array}$ & $\begin{array}{l}0.45 \\
(0.11)\end{array}$ & $\begin{array}{l}-0.09 \\
(0.75)\end{array}$ & $\begin{array}{l}-0.15 \\
(0.59)\end{array}$ & $\begin{array}{l}-0.03 \\
(0.91)\end{array}$ & $\begin{array}{l}0.27 \\
(0.33)\end{array}$ & $\begin{array}{l}-0.21 \\
(0.45)\end{array}$ & $\begin{array}{l}0.09 \\
(0.75)\end{array}$ & $\begin{array}{l}-0.27 \\
(0.33)\end{array}$ \\
\hline & Term length & $\begin{array}{l}0.67 \\
(0.01)\end{array}$ & $\begin{array}{l}0.39 \\
(0.14)\end{array}$ & $\begin{array}{l}0.00 \\
(1.00)\end{array}$ & $\begin{array}{l}-0.17 \\
(0.53)\end{array}$ & $\begin{array}{l}0.00 \\
(1.00)\end{array}$ & $\begin{array}{l}0.00 \\
(1.00)\end{array}$ & $\begin{array}{c}-0.33 \\
(0.21)\end{array}$ & $\begin{array}{l}-0.22 \\
(.40)\end{array}$ & $\begin{array}{c}-0.28 \\
(0.30)\end{array}$ \\
\hline
\end{tabular}

(1) The p-value is the smallest level of significance at which the null hypothesis would be rejected In this table, a low p-value indicates that the observed departare of the statistic from 0 is unlikely to be a result of chance.

(2) In addition to doing the rankings by region of birth, we did them by state of birth. The results were similar.

*This table was constructed by:

1) Calculating mean log wages within region of residence/region of birth cells.

2) Calculating average quality measures for regions of birth. (These are weighted averages of the state quality data.)

3) For each region of residence, calculating the conrelation of the ranks of log wages by region of birth with the corresponding ranks in quality.

Abbreviations for regions:

NE - New England

WNC - West North Central

WSC - West South Central
MA - Middle Adiantic

SA - South Atlantic

ML - Mountain
ENC - East North Central

ESC - East South Central

Pac. - Pacific 
TABLE 4(b)

1980 Census, Individuals with Education Level = 4 or more years college Kendall Tau Correlations Between Region of Birth Quality Rankings

and Region of Birth Log Wage Rankings. *

(Correlations done separately within the nine regions of residence.)

\begin{tabular}{|c|c|c|c|c|c|c|c|c|c|c|}
\hline & & \multicolumn{9}{|c|}{ Region of Residence } \\
\hline & & $\mathrm{NE}$ & $\mathrm{MA}$ & ENC & WNC & $\mathrm{SA}$ & ESC & WSC & Mt. & Pac. \\
\hline \multirow[t]{4}{*}{$1920-29$} & PTR-E & $\begin{array}{l}0.56 \\
(0.04)\end{array}$ & $\begin{array}{l}-0.22 \\
(0.40)\end{array}$ & $\begin{array}{l}-0.11 \\
(0.68)\end{array}$ & $\begin{array}{l}0.00 \\
(1.00)\end{array}$ & $\begin{array}{c}-0.39 \\
(0.14)\end{array}$ & $\begin{array}{l}-0.11 \\
(0.68)\end{array}$ & $\begin{array}{c}-0.11 \\
(0.68)\end{array}$ & $\begin{array}{l}0.39 \\
(0.14)\end{array}$ & $\begin{array}{l}0.00 \\
(1.00)\end{array}$ \\
\hline & PTR-A & $\begin{array}{l}0.44 \\
(0.10)\end{array}$ & $\begin{array}{l}-0.22 \\
(0.40)\end{array}$ & $\begin{array}{l}-0.44 \\
(0.10)\end{array}$ & $\begin{array}{l}0.22 \\
(0.40)\end{array}$ & $\begin{array}{c}-0.50 \\
(0.06)\end{array}$ & $\begin{array}{l}0.11 \\
(0.68)\end{array}$ & $\begin{array}{c}-0.11 \\
(0.68)\end{array}$ & $\begin{array}{l}0.50 \\
(0.06)\end{array}$ & $\begin{array}{l}0.11 \\
(0.68)\end{array}$ \\
\hline & Teacher salary & $\begin{array}{l}-0.15 \\
(0.59)\end{array}$ & $\begin{array}{l}0.62 \\
(0.02)\end{array}$ & $\begin{array}{l}0.45 \\
(0.10)\end{array}$ & $\begin{array}{l}-0.21 \\
(0.45)\end{array}$ & $\begin{array}{l}0.57 \\
(0.04)\end{array}$ & $\begin{array}{l}-0.27 \\
(0.33)\end{array}$ & $\begin{array}{l}0.03 \\
(0.91)\end{array}$ & $\begin{array}{l}-0.21 \\
(0.45)\end{array}$ & $\begin{array}{c}-0.15 \\
(0.59)\end{array}$ \\
\hline & Term length & $\begin{array}{l}-0.50 \\
(0.06)\end{array}$ & $\begin{array}{l}-0.17 \\
(0.53)\end{array}$ & $\begin{array}{l}-0.06 \\
(0.83)\end{array}$ & $\begin{array}{l}0.50 \\
(0.06)\end{array}$ & $\begin{array}{l}0.00 \\
(1.00)\end{array}$ & $\begin{array}{l}0.28 \\
(0.30)\end{array}$ & $\begin{array}{l}0.50 \\
(0.06)\end{array}$ & $\begin{array}{l}0.22 \\
(0.40)\end{array}$ & $\begin{array}{l}0.17 \\
(0.53)\end{array}$ \\
\hline \multirow[t]{4}{*}{$1930-39$} & PTR-E & $\begin{array}{l}0.17 \\
(0.53)\end{array}$ & $\begin{array}{l}0.17 \\
(0.53)\end{array}$ & $\begin{array}{l}-0.33 \\
(0.21)\end{array}$ & $\begin{array}{l}0.17 \\
(0.53)\end{array}$ & $\begin{array}{c}-0.22 \\
(0.40)\end{array}$ & $\begin{array}{c}-0.28 \\
(0.30)\end{array}$ & $\begin{array}{l}0.06 \\
(0.83)\end{array}$ & $\begin{array}{l}-0.28 \\
(0.30)\end{array}$ & $\begin{array}{l}-0.28 \\
(0.30)\end{array}$ \\
\hline & PTR-A & $\begin{array}{l}0.00 \\
(1.00)\end{array}$ & $\begin{array}{l}0.11 \\
(0.68)\end{array}$ & $\begin{array}{l}-0.39 \\
(0.14)\end{array}$ & $\begin{array}{l}0.33 \\
(0.21)\end{array}$ & $\begin{array}{l}-0.28 \\
(0.30)\end{array}$ & $\begin{array}{c}-0.33 \\
(0.21)\end{array}$ & $\begin{array}{l}0.22 \\
(0.40)\end{array}$ & $\begin{array}{l}-0.33 \\
(0.21)\end{array}$ & $\begin{array}{l}-0.11 \\
(0.68)\end{array}$ \\
\hline & Teacher salary & $\begin{array}{l}-0.47 \\
(0.10)\end{array}$ & $\begin{array}{l}-0.47 \\
(0.10)\end{array}$ & $\begin{array}{l}0.04 \\
(0.90)\end{array}$ & $\begin{array}{l}0.11 \\
(0.71)\end{array}$ & $\begin{array}{l}0.04 \\
(0.90)\end{array}$ & $\begin{array}{l}0.11 \\
(0.71)\end{array}$ & $\begin{array}{l}0.40 \\
(0.17)\end{array}$ & $\begin{array}{l}-0.25 \\
(0.38)\end{array}$ & $\begin{array}{c}-0.11 \\
(0.71)\end{array}$ \\
\hline & Term length & $\begin{array}{l}-0.50 \\
(0.06)\end{array}$ & $\begin{array}{l}-0.50 \\
(0.06)\end{array}$ & $\begin{array}{l}0.44 \\
(0.09)\end{array}$ & $\begin{array}{l}-0.06 \\
(0.83)\end{array}$ & $\begin{array}{l}0.00 \\
(1.00)\end{array}$ & $\begin{array}{l}0.28 \\
(0.30)\end{array}$ & $\begin{array}{l}0.28 \\
(0.30)\end{array}$ & $\begin{array}{l}-0.06 \\
(0.83)\end{array}$ & $\begin{array}{l}0.06 \\
(0.83)\end{array}$ \\
\hline \multirow[t]{4}{*}{$1940-49$} & PTR-E & $\begin{array}{l}0.22 \\
(0.40)\end{array}$ & $\begin{array}{l}0.06 \\
(0.83)\end{array}$ & $\begin{array}{l}-0.17 \\
(0.53)\end{array}$ & $\begin{array}{l}0.06 \\
(0.83)\end{array}$ & $\begin{array}{l}-0.50 \\
(0.06)\end{array}$ & $\begin{array}{l}-0.44 \\
(0.10)\end{array}$ & $\begin{array}{l}-0.11 \\
(0.68)\end{array}$ & $\begin{array}{l}0.22 \\
(0.40)\end{array}$ & $\begin{array}{c}-0.11 \\
(0.68)\end{array}$ \\
\hline & PTR-A & $\begin{array}{l}0.11 \\
(0.68)\end{array}$ & $\begin{array}{l}0.06 \\
(0.83)\end{array}$ & $\begin{array}{l}-0.28 \\
(0.30)\end{array}$ & $\begin{array}{l}-0.06 \\
(0.83)\end{array}$ & $\begin{array}{l}-0.50 \\
(0.06)\end{array}$ & $\begin{array}{c}-0.56 \\
(0.04)\end{array}$ & $\begin{array}{c}-0.22 \\
(0.40)\end{array}$ & $\begin{array}{l}0.11 \\
(0.68)\end{array}$ & $\begin{array}{c}-0.22 \\
(0.40)\end{array}$ \\
\hline & Teacher salary & $\begin{array}{l}-0.15 \\
(0.59)\end{array}$ & $\begin{array}{l}0.39 \\
(0.16)\end{array}$ & $\begin{array}{l}0.33 \\
(0.24)\end{array}$ & $\begin{array}{l}-0.03 \\
(0.91)\end{array}$ & $\begin{array}{l}-0.03 \\
(0.91)\end{array}$ & $\begin{array}{l}0.15 \\
(0.60)\end{array}$ & $\begin{array}{l}-0.14 \\
(0.60)\end{array}$ & $\begin{array}{l}0.27 \\
(0.33)\end{array}$ & $\begin{array}{l}0.21 \\
(0.45)\end{array}$ \\
\hline & Term length & $\begin{array}{l}-0.17 \\
(0.53)\end{array}$ & $\begin{array}{l}-0.33 \\
(0.21)\end{array}$ & $\begin{array}{l}0.00 \\
(1.00)\end{array}$ & $\begin{array}{l}0.22 \\
(0.40)\end{array}$ & $\begin{array}{l}0.00 \\
(1.00)\end{array}$ & $\begin{array}{l}0.39 \\
(0.14)\end{array}$ & $\begin{array}{l}0.39 \\
(0.14)\end{array}$ & $\begin{array}{l}-0.28 \\
(0.29)\end{array}$ & $\begin{array}{l}0.17 \\
(0.53)\end{array}$ \\
\hline
\end{tabular}

(1) The p-value is the smallest level of significance at which the null hypothesis would be rejected. In this table, a low p-value incicates that the observed departure of the statistic from 0 is unlikely to be a result of chance.

(2) In addition to doing the rankings by region of birh, we did them by state of birth. The results were similar.

*This table was constructed by:

1) Calculating mean log wages within region of residence/region of birth cells.

2) Calculating average quality measures for regions of birth. (These are weighted averages of the state quality data.)

3) For each region of residence, calculating the correlation of the ranks of log wages by region of birth with the corresponding ranks in quality.

Abbreviations for regions:

NE - New England

WNC - West North Central

WSC - West South Central
MA - Middle Adantic

SA - South Atlantic

Mt. - Mountain
ENC - East North Central

ESC - East South Central

Pac. - Pacific 
TABLE 5

Nonparametric Tests for Agreement in

Region of Birth Average Wage Rankings Across Regions of Residence

$P$-values given in parentheses.

\begin{tabular}{|c|c|c|c|c|}
\hline Census Year & Cohort & 12th Grade & 1-3 Yrs. College & $\begin{array}{c}4 \text { or more Yrs. } \\
\text { College }\end{array}$ \\
\hline \multirow[t]{4}{*}{1970} & $1910-19$ & $\begin{array}{c}0.18 \\
(0.1255)\end{array}$ & $\begin{array}{c}0.06 \\
(0.8061)\end{array}$ & $\begin{array}{c}0.09 \\
(0.6124)\end{array}$ \\
\hline & $1920-29$ & $\begin{array}{c}0.20 \\
(0.0769)\end{array}$ & $\begin{array}{c}0.21 \\
(0.0543)\end{array}$ & $\begin{array}{c}0.22 \\
(0.0424)\end{array}$ \\
\hline & $1930-39$ & $\begin{array}{c}0.18 \\
(0.1106) \\
\end{array}$ & $\begin{array}{c}0.06 \\
(0.8091) \\
\end{array}$ & $\begin{array}{c}0.25 \\
(0.0227)\end{array}$ \\
\hline & $1940-49$ & $\begin{array}{c}0.14 \\
(0.2788) \\
\end{array}$ & $\begin{array}{c}0.06 \\
(0.8091) \\
\end{array}$ & $\begin{array}{c}0.18 \\
(0.12) \\
\end{array}$ \\
\hline \multirow[t]{3}{*}{1980} & $1920-29$ & $\begin{array}{c}0.10 \\
(0.4965) \\
\end{array}$ & $\begin{array}{c}0.13 \\
(0.3079) \\
\end{array}$ & $\begin{array}{c}0.10 \\
(0.4965) \\
\end{array}$ \\
\hline & $1930-39$ & $\begin{array}{c}0.20 \\
(0.0719) \\
\end{array}$ & $\begin{array}{c}0.24 \\
(0.0252) \\
\end{array}$ & $\begin{array}{c}0.09 \\
(0.5992) \\
\end{array}$ \\
\hline & $1940-49$ & $\begin{array}{c}0.19 \\
(0.0919)\end{array}$ & $\begin{array}{c}0.26 \\
(0.0180)\end{array}$ & $\begin{array}{c}0.33 \\
(0.0023)\end{array}$ \\
\hline \multirow[t]{3}{*}{1990} & $1930-39$ & $\begin{array}{c}0.32 \\
(0.004) \\
\end{array}$ & $\begin{array}{c}0.14 \\
(0.25)\end{array}$ & $\begin{array}{c}0.22 \\
(0.04)\end{array}$ \\
\hline & $1940-49$ & $\begin{array}{c}0.26 \\
(0.02) \\
\end{array}$ & $\begin{array}{c}0.32 \\
(0.004) \\
\end{array}$ & $\begin{array}{c}0.35 \\
(0.002) \\
\end{array}$ \\
\hline & $1950-59$ & $\begin{array}{c}0.17 \\
(0.13) \\
\end{array}$ & $\begin{array}{c}0.52 \\
(0.0001) \\
\end{array}$ & $\begin{array}{c}0.48 \\
(0.0003) \\
\end{array}$ \\
\hline
\end{tabular}

(1) The Kendall Coefficient of Concordance for measuring the relative agreement between $\mathrm{m}$ rankings of $\mathrm{n}$ objects is given by $W=\frac{12 S}{m^{2}\left(n^{3}-n\right)}$, where $S=\sum_{i=1}^{n}\left[R_{i} \frac{m(n+1)}{2}\right]^{2}$ and $R_{i}$ is the sum of the ranks for object $i$. For $n>7, \chi_{r}^{2}=m(n-1) W$ is approximately $\chi^{2}$ with $n-1$ degrees of freedom. When all rankings agree, $W=1$. As $W$ gets closer to 0 , there is less agreement in the rankings.

(2) Regions of birth and regions of residence refer to the nine Census regions: New England, Middle Atlantic, East North Central, West North Central, South Atlantic, East South Central, West South Central, Mountain, and Pacific.

(3) The p-value is the smallest level of significance at which the null hypothesis would be rejected. In this table, a low $p$-value indicates that the observed departure of the statistic from 0 is unlikely to be a result of chance. 
TABLE 6

Kendall Tau Correlations Between Different Quality Measures by Birth Cohort

$P$-values given in parentheses

\begin{tabular}{|c|c|c|c|c|}
\hline \multicolumn{5}{|c|}{ Measures of Schooling Quality } \\
\hline Birth Cohort & & $\begin{array}{c}\text { PT ratio } \\
\text { (enrollment) }\end{array}$ & $\begin{array}{c}\text { PT ratio } \\
\text { (attendance) }\end{array}$ & $\begin{array}{l}\text { Teacher } \\
\text { salary }\end{array}$ \\
\hline $1920-29$ & $\begin{array}{l}\text { PT ratio (attendance) } \\
\text { Teacher salary } \\
\text { Term length }\end{array}$ & $\begin{array}{c}0.79 \\
(0.00) \\
0.05 \\
(0.61) \\
-0.15 \\
(0.13) \\
\end{array}$ & $\begin{array}{c}\cdots \\
0.21 \\
(0.03) \\
0.00 \\
(0.98) \\
\end{array}$ & $\begin{array}{c}\cdots \\
\ldots \\
0.27 \\
(0.01) \\
\end{array}$ \\
\hline $1930-39$ & $\begin{array}{l}\text { PT ratio (attendance) } \\
\text { Teacher salary } \\
\text { Term length }\end{array}$ & $\begin{array}{c}0.83 \\
(0.00) \\
0.10 \\
(0.07) \\
-0.13 \\
(0.02) \\
\end{array}$ & $\begin{array}{c}\cdots \\
0.09 \\
(0.35) \\
-0.10 \\
(.033) \\
\end{array}$ & $\begin{array}{c}\cdots \\
\\
\cdots \\
0.10 \\
(0.30) \\
\end{array}$ \\
\hline $1940-49$ & $\begin{array}{l}\text { PT ratio (attendance) } \\
\text { Teacher salary } \\
\text { Term length }\end{array}$ & $\begin{array}{c}0.80 \\
(0.00) \\
0.10 \\
(0.07) \\
-0.13 \\
(0.02) \\
\end{array}$ & $\begin{array}{c}\cdots \\
0.08 \\
(0.41) \\
-0.11 \\
(0.27) \\
\end{array}$ & $\begin{array}{c}\cdots \\
\cdots \\
0.43 \\
(0.00) \\
\end{array}$ \\
\hline
\end{tabular}

(1) "PT ratio" refers to pupil-teacher ratio. The quality indices are described in detail in Appendix B.

(2) The pairwise rank correlations are calculated by ranking the states according to two quality measures. and calculating the correlation among the ranks.

(3) The p-value is the smallest level of significance at which the null hypothesis would be rejected. In this table, a low p-value indicates that the observed departure of the statistic from 0 is unlikely to be a result of chance. 
Table 7a

1980 Census: The Effect of Schooling Quality on the Rate of Return to Education Linear Model

Second Stage Model: Rate of Return $=\alpha+\alpha_{b}+\alpha_{7(s)}+\alpha_{c}+\alpha_{b c}+\alpha_{r(s)}$

(Eicker-White standard errors in parentheses)

\begin{tabular}{|c|c|c|c|c|c|c|c|c|c|}
\hline \multirow[b]{3}{*}{ Coefficient Estimates } & \multicolumn{9}{|c|}{ Second Stage Model Restrictions } \\
\hline & (1) & (2) & (3) & \multicolumn{3}{|c|}{ (4) } & (5) & (6) & (7) \\
\hline & $\alpha_{b c}=\varphi Q_{b c}$ & $\alpha_{b c}=\varphi Q_{b c}$ & $\alpha_{b}+\alpha_{b c}$ & \multicolumn{3}{|c|}{$\alpha_{b c}=\varphi_{c} Q_{b c}$} & $\alpha_{b c}=\varphi Q_{b c}$ & $\alpha_{b c}=\varphi Q_{b c}$ & $\alpha_{b c}=\varphi Q_{b c}$ \\
\hline \multirow{3}{*}{ Pupil-Teacher Ratio } & & & & $20 \mathrm{~s}$ & $30 \mathrm{~s}$ & $40 \mathrm{~s}$ & & & \\
\hline & -5.66 & -6.27 & 1.36 & -0.09 & 2.58 & 2.02 & -6.27 & -6.27 & -6.27 \\
\hline & (1.48) & (1.49) & $(0.55)$ & (1.03) & $(0.75)$ & $(0.97)$ & (2.69) & (2.63) & (1.88) \\
\hline \multirow[t]{2}{*}{ Term Length } & $\ldots$ & 1.07 & 3.06 & 2.23 & 3.59 & 4.39 & 1.07 & 1.07 & 1.07 \\
\hline & & $(0.49)$ & $(0.24)$ & $(0.33)$ & $(0.44)$ & $(0.66)$ & (1.04) & $(1.01)$ & $(0.67)$ \\
\hline Relative Teacher & $\ldots$ & 2.08 & 0.98 & 1.27 & 0.83 & 0.54 & 2.08 & 2.08 & 2.08 \\
\hline sutwy & & & & & & & & & \\
\hline \multicolumn{10}{|l|}{$\begin{array}{l}\text { Demand and Supply } \\
\text { Aggregates }\end{array}$} \\
\hline reg. avg. P.T. Ratio & ... & $\ldots$ & $\ldots$ & $\ldots$ & ... & $\ldots$ & 14.49 & 11.03 & -29.44 \\
\hline reg. avg. Term Length & $\ldots$ & ... & $\cdots$ & $\ldots$ & ... & $\ldots$ & $\ldots$ & -5.15 & -1.33 \\
\hline of 12 vears & 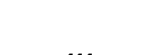 & 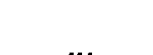 & 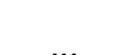 & & & & & $(0.51)$ & $(1.32)$ \\
\hline$\% 12$ years & & & $\cdots$ & $\cdots$ & $\cdots$ & $\cdots$ & $\cdots$ & $\cdots$ & $(0.02)$ \\
\hline$\% 1-3$ years college & $\ldots$ & $\cdots$ & $\ldots$ & $\cdots$ & ... & ... & ... & ... & -0.27 \\
\hline$\% 4+$ college & $\ldots$ & $\ldots$ & $\ldots$ & $\ldots$ & $\ldots$ & $\ldots$ & $\ldots$ & $\ldots$ & $\begin{array}{c}(0.01) \\
0.05\end{array}$ \\
\hline & & & & & & & & & $(0.026)$ \\
\hline$\%$ manufacturing & $\ldots$ & $\ldots$ & ... & $\cdots$ & $\cdots$ & $\ldots$ & $\cdots$ & $\ldots$ & 0.01 \\
\hline & & & & & & & & & $(0.004)$ \\
\hline
\end{tabular}

(1) The number of observations $=1323$ (49 states of birth $\times 9$ regions $\times 3$ cohorts)

(2) The $\%$ of the workforce in the manufacturing industry was computed from the 1980 Census (Sample A) using male and female workers age 18-65. The mean quality within a region of residence was calculated using the 20-29, 30-39, and $40-49$ birth cohorts.

(3) The omitted education category is $<12$ years.

(4) The pupil-teacher ratio and term length were divided by 100 in the regression. The attendance based pupil-teacher ratio was used. 
Table 9a

1980 Census: The Effect of Schooling Quality on Fixed Effects

Linear Model

Second Stage Model: $\theta_{\mathrm{bsc}}=\theta+\theta_{\mathrm{b}}+\theta_{\mathrm{s}}+\theta_{\mathrm{c}}+\theta_{\mathrm{bc}}+\theta_{\mathrm{r}(\mathrm{s}) \mathrm{c}}$

(Eicker-White standard errors in parentheses)

\begin{tabular}{|c|c|c|c|c|c|c|c|c|c|}
\hline & \multicolumn{9}{|c|}{ Model Specification } \\
\hline & (1) & (2) & (3) & \multicolumn{3}{|c|}{ (4) } & (5) & (6) & (7) \\
\hline Coefficients: & $\theta_{\mathrm{bc}}=\varphi \mathrm{Q}_{\mathrm{bc}}$ & $\theta_{b c}=\varphi Q_{b c}$ & $\begin{array}{l}\theta_{b}+\theta_{b c} \\
=\varphi Q_{b c}\end{array}$ & \multicolumn{3}{|c|}{$\theta_{b c}=\varphi_{c} Q_{b c}$} & $\begin{array}{c}\theta_{\mathrm{bc}}=\varphi \mathrm{Q}_{\mathrm{bc}} \\
\theta_{\mathrm{s}}+\theta_{\mathrm{sc}}= \\
\pi_{1} \mathrm{Q}_{\mathrm{r}(\mathrm{s})}\end{array}$ & $\begin{array}{c}\theta_{\mathrm{bc}}=\varphi \mathrm{Q}_{\mathrm{bc}} \\
\theta_{\mathrm{s}}+\theta_{\mathrm{r}(\mathrm{s})}= \\
\pi_{1} \mathrm{Q}_{\mathrm{r}(\mathrm{s})}\end{array}$ & $\begin{array}{c}\theta_{\mathrm{bb}}=\varphi \mathrm{Q}_{\mathrm{bc}} \\
\theta_{\mathrm{s}}+\theta_{\mathrm{r}(\mathrm{s})}=\pi_{1} \mathrm{Q}_{\mathrm{rs})} \\
+\pi_{2} \mathrm{D}_{\mathrm{r}(\mathrm{s})}\end{array}$ \\
\hline Cohort: & & & & $20 s$ & $30 \mathrm{~s}$ & $40 \mathrm{~s}$ & & & \\
\hline Pupil-Teacher & 0.93 & 1.02 & -0.38 & -0.19 & -0.59 & -0.40 & 1.02 & 1.02 & 1.03 \\
\hline Ratio & $(0.14)$ & $(0.14)$ & $(0.05)$ & $(0.08)$ & $(0.07)$ & $(0.09)$ & $(0.23)$ & $(0.23)$ & $(0.17)$ \\
\hline Term Length & $\ldots$ & -0.18 & -0.52 & -0.41 & -0.60 & -0.69 & -0.18 & -0.19 & -0.17 \\
\hline & & $(0.05)$ & $(0.02)$ & $(0.03)$ & $(0.04)$ & $(0.07)$ & $(0.09)$ & $(0.09)$ & $(0.07)$ \\
\hline Relative Teacher & $\ldots$ & -0.27 & -0.10 & -0.13 & -0.08 & -0.07 & -0.27 & -0.27 & -0.27 \\
\hline Salary & & $(0.02)$ & $(0.01)$ & $(0.01)$ & $(0.01)$ & $(0.02)$ & $(0.04)$ & $(0.04)$ & $(0.03)$ \\
\hline Demand and & & & & & & & & & \\
\hline Supply & & & & & & & & & \\
\hline Aggregates & & & & & & & & & \\
\hline reg. avg. PTR-A & $\cdots$ & $\cdots$ & ... & $\ldots$ & $\cdots$ & $\cdots$ & 0.70 & 0.71 & 8.11 \\
\hline & & & & & & & $(0.15)$ & $(0.15)$ & (0.34) \\
\hline reg. avg. Term & $\ldots$ & $\ldots$ & $\ldots$ & $\ldots$ & $\cdots$ & $\ldots$ & $\ldots$ & 0.66 & 0.77 \\
\hline $\begin{array}{l}\text { Length } \\
\% 12 \text { years }\end{array}$ & $\ldots$ & $\ldots$ & $\ldots$ & $\ldots$ & $\ldots$ & $\ldots$ & $\ldots$ & $\begin{array}{l}(0.09) \\
\ldots\end{array}$ & $\begin{array}{c}(0.16) \\
0.04\end{array}$ \\
\hline & & & & & & & & & $(0.01)$ \\
\hline$\% 1-3$ years & $\ldots$ & $\ldots$ & $\ldots$ & $\ldots$ & $\ldots$ & $\ldots$ & $\ldots$ & $\ldots$ & 0.04 \\
\hline$\% 4+$ college & $\ldots$ & $\ldots$ & $\ldots$ & ... & $\ldots$ & $\ldots$ & $\ldots$ & $\ldots$ & $\begin{array}{l}(0.01) \\
-0.01\end{array}$ \\
\hline & & & & & & & & & $(0.01)$ \\
\hline$\%$ manufacturing & $\ldots$ & $\ldots$ & ... & $\ldots$ & $\ldots$ & $\ldots$ & $\ldots$ & $\ldots$ & 0.003 \\
\hline
\end{tabular}

(1) The number of observations $=7497$ ( 49 states of birth $\times 51$ states of residence $\times 3$ cohorts).

(2) The \% of the workforce in the manufacturing industry was computed from the 1980 Census (A Sample) using male and female workers age 18-65. The mean quality within a region of residence was calculated using the 20-29,30-39, and 40-49 birth cohorts.

(3) The pupil-teacher ratio and term length were divided by 100 in the regression. The attendance based pupil-teacher ratio was used. 
TABLE 10

F-Tests for Linear Functional Form

\begin{tabular}{|c|c|c|c|c|c|c|c|c|c|c|}
\hline \multicolumn{2}{|c|}{ Census Sample: } & \multicolumn{3}{|c|}{1970} & \multicolumn{3}{|c|}{1980} & \multicolumn{3}{|c|}{1990} \\
\hline $\begin{array}{l}\text { Birth } \\
\text { Cohort }\end{array}$ & $\begin{array}{l}\text { Sheepskin } \\
\text { Effect at: }\end{array}$ & $\begin{array}{c}8 \\
\text { Yrs }\end{array}$ & $\begin{array}{c}12 \\
\text { Yrs } \\
\end{array}$ & $\begin{array}{c}16 \\
\text { Yrs }\end{array}$ & $\begin{array}{c}8 \\
\text { Yrs } \\
\end{array}$ & $\begin{array}{c}12 \\
\text { Yrs }\end{array}$ & $\begin{array}{c}16 \\
\text { Yrs }\end{array}$ & $\begin{array}{c}8 \\
\text { Yrs }\end{array}$ & $\begin{array}{c}12 \\
\text { Yrs }\end{array}$ & $\begin{array}{l}16 \\
\text { Yrs }\end{array}$ \\
\hline 1910-19 & $\begin{array}{l}\text { F Statistic } \\
\text { P-value }\end{array}$ & $\begin{array}{l}1.62 \\
0.00\end{array}$ & $\begin{array}{l}0.90 \\
0.66\end{array}$ & $\begin{array}{l}8.38 \\
0.00\end{array}$ & NA & NA & NA & NA & NA & $\mathrm{NA}$ \\
\hline $1920-29$ & $\begin{array}{l}\text { F Statistic } \\
\text { P-value }\end{array}$ & $\begin{array}{l}1.35 \\
0.05 \\
\end{array}$ & $\begin{array}{l}1.15 \\
0.22 \\
\end{array}$ & $\begin{array}{c}14.45 \\
0.00 \\
\end{array}$ & $\begin{array}{l}1.31 \\
0.00 \\
\end{array}$ & $\begin{array}{l}2.48 \\
0.00 \\
\end{array}$ & $\begin{array}{l}25.5 \\
0.00 \\
\end{array}$ & $\overline{\text { NA }}$ & $\overline{\mathrm{NA}}$ & NA \\
\hline 1930-39 & $\begin{array}{l}F \text { Statistic } \\
\text { P-value }\end{array}$ & $\begin{array}{l}1.96 \\
0.00\end{array}$ & $\begin{array}{l}1.04 \\
0.40\end{array}$ & $\begin{array}{l}9.27 \\
0.00\end{array}$ & $\begin{array}{l}3.30 \\
0.00\end{array}$ & $\begin{array}{l}6.91 \\
0.00\end{array}$ & $\begin{array}{l}35.1 \\
0.00\end{array}$ & $\begin{array}{l}3.67 \\
0.00\end{array}$ & $\begin{array}{l}2.00 \\
0.00\end{array}$ & $\begin{array}{l}14.07 \\
0.00\end{array}$ \\
\hline $1940-49$ & $\begin{array}{l}F \text { Statistic } \\
\text { P-value }\end{array}$ & $\begin{array}{l}3.56 \\
0.00\end{array}$ & $\begin{array}{l}3.91 \\
0.00\end{array}$ & $\begin{array}{l}9.15 \\
0.00\end{array}$ & $\begin{array}{l}4.21 \\
0.00\end{array}$ & $\begin{array}{l}12.6 \\
0.00\end{array}$ & $\begin{array}{l}22.1 \\
0.00\end{array}$ & $\begin{array}{l}6.21 \\
0.00\end{array}$ & $\begin{array}{l}2.99 \\
0.00\end{array}$ & $\begin{array}{c}16.37 \\
0.00\end{array}$ \\
\hline $1950-59$ & $\begin{array}{l}\text { F-Statistic } \\
\text { P-value }\end{array}$ & NA & NA & NA & NA & NA & NA & $\begin{array}{c}14.35 \\
0.00\end{array}$ & $\begin{array}{c}16.22 \\
0.00\end{array}$ & $\begin{array}{c}49.53 \\
0.00\end{array}$ \\
\hline
\end{tabular}


Table 11.1(a)

1980 Census: The Effect of Schooling Quality on the Linear Base Return to Education Nonlinear Model

Second Stage Model: Rate of Retum $=\alpha+\alpha_{b}+\alpha_{i(s)}+\alpha_{c}+\alpha_{b c}+\alpha_{i(s h}$ (Eicker-White standard errors in parentheses)

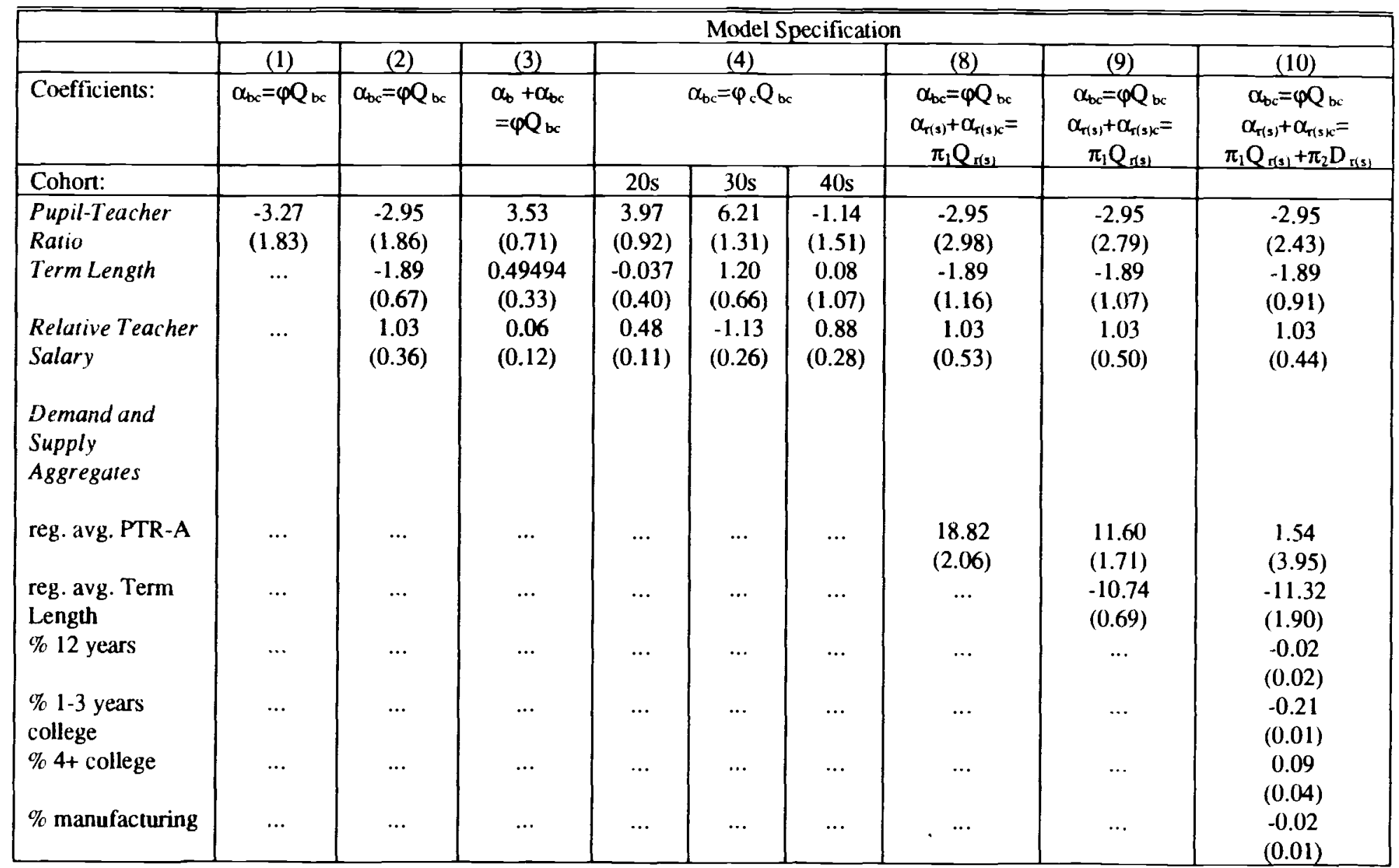

(1) The number of observations $=1323$ (49 states of birth $\times 9$ regions $\times 3$ cohorts).

(2) The \% of the workforce in the manufacturing industry was computed from the 1980 Census (A Sample) using male and female workers age 18-65. The mean quality within a region of residence was calculated using the 20-29,30-39, and 40-49 birth cohorts.

(3) The pupil-teacher ratio and term length were divided by 100 in the regression. The attendance based pupil-teacher ratio was used. 
Table 11.2(a)

1980 Census: The Effect of Schooling Quality on the Marginal Rate of Return to 1-3 Years of College Nonlinear Model

Second Stage Model: Rate of Return $=\alpha+\alpha_{b}+\alpha_{t(s)}+\alpha_{c}+\alpha_{b c}+\alpha_{t(s) c}$

(Eicker-White standard errors in parentheses)

\begin{tabular}{|c|c|c|c|c|c|c|c|c|c|}
\hline & \multicolumn{9}{|c|}{ Model Specification } \\
\hline & (1) & (2) & (3) & \multicolumn{3}{|c|}{ (4) } & $(8)$ & (9) & (10) \\
\hline Coefficients: & $\alpha_{b c}=\varphi Q_{b c}$ & $\alpha_{b c}=\varphi Q_{b c}$ & $\alpha_{b}+\alpha_{b c}$ & \multicolumn{3}{|c|}{$\alpha_{b c}=\varphi_{c} Q_{b c}$} & $\alpha_{b c}=\varphi Q_{b c}$ & $\alpha_{b c}=\varphi Q_{b c}$ & $\alpha_{b c}=\varphi Q_{b c}$ \\
\hline Cohort: & & & & $20 \mathrm{~s}$ & $30 \mathrm{~s}$ & $40 \mathrm{~s}$ & & & \\
\hline Pupil-Teacher & -23.51 & -29.01 & 12.25 & -5.95 & 18.99 & 32.24 & -29.01 & -29.01 & -29.01 \\
\hline Ratio & (13.03) & (12.59) & (3.79) & $(7.06)$ & $(5.58)$ & $(5.66)$ & (14.48) & $(14.45)$ & $(13.22)$ \\
\hline Term Length & $\ldots$ & 17.36 & 15.04 & 16.28 & 10.12 & 17.85 & 17.36 & 17.36 & 17.36 \\
\hline Relative Teacher & $\ldots$ & $\begin{array}{c}(3.30) \\
6.56\end{array}$ & $\begin{array}{c}(1.68) \\
2.97\end{array}$ & $\begin{array}{c}(2.48) \\
2.62\end{array}$ & $\begin{array}{c}(3.00) \\
8.44\end{array}$ & $\begin{array}{l}(4.85) \\
-5.18\end{array}$ & $\begin{array}{c}(4.37) \\
6.56\end{array}$ & $\begin{array}{c}(4.33) \\
6.56\end{array}$ & $\begin{array}{c}(3.66) \\
6.56\end{array}$ \\
\hline Salary & & (2.21) & $(0.74)$ & (1.15) & $(1.02)$ & $(1.08)$ & $(2.50)$ & (2.50) & $(2.30)$ \\
\hline $\begin{array}{l}\text { Demand and } \\
\text { Supply } \\
\text { Aggregates }\end{array}$ & & & & & & & & & \\
\hline reg. avg. PTR-A & $\cdots$ & $\cdots$ & $\cdots$ & $\cdots$ & $\cdots$ & $\cdots$ & $\begin{array}{l}-51.80 \\
(7.52)\end{array}$ & $\begin{array}{l}-30.65 \\
(7.64)\end{array}$ & $\begin{array}{l}-247.13 \\
(18.40)\end{array}$ \\
\hline $\begin{array}{l}\text { reg. avg. Term } \\
\text { Length }\end{array}$ & $\cdots$ & $\ldots$ & $\cdots$ & $\ldots$ & ... & $\cdots$ & $\ldots$ & $\begin{array}{l}31.44 \\
(3.20)\end{array}$ & $\begin{array}{l}72.05 \\
(9.03)\end{array}$ \\
\hline$\% 12$ years & $\cdots$ & $\cdots$ & $\cdots$ & $\cdots$ & $\cdots$ & $\cdots$ & $\ldots$ & $\ldots$ & $\begin{array}{l}-1.16 \\
(0.11)\end{array}$ \\
\hline $\begin{array}{l}\% 1-3 \text { years } \\
\text { college }\end{array}$ & $\cdots$ & $\ldots$ & $\cdots$ & $\cdots$ & ... & $\cdots$ & ... & $\ldots$ & $\begin{array}{l}-0.54 \\
(0.06)\end{array}$ \\
\hline$\% 4+$ college & $\cdots$ & $\cdots$ & $\cdots$ & $\cdots$ & ... & $\cdots$ & ... & $\ldots$ & $\begin{array}{l}-0.67 \\
(0.18)\end{array}$ \\
\hline \% manufacturing & $\cdots$ & $\ldots$ & ... & ... & ... & $\cdots$ & $\cdots$ & $\ldots$ & $\begin{array}{c}0.30 \\
(0.031)\end{array}$ \\
\hline
\end{tabular}

(1) The number of observations $=1323$ (49 states of birth $\times 9$ regions $\times 3$ cohorts).

(2) The $\%$ of the workforce in the manufacturing industry was computed from the 1980 Census (A Sample) using male and female workers age 18-65. The mean quality within a region of residence was calculated using the 20-29, 30-39, and 40-49 birth cohorts.

(3) The pupil-teacher ratio and term length were divided by 100 in the regression. The attendance based pupil-teacher ratio was used. 
Table 11.3(a)

1980 Census: The Effect of Schooling Quality on the Marginal Rate of Return to 4 Plus Years of College Nonlinear Model

Second Stage Model: Rate of Retum $=\alpha+\alpha_{b}+\alpha_{i(s)}+\alpha_{c}+\alpha_{b c}+\alpha_{i(s k}$

(Eicker-White standard errors in parentheses)

\begin{tabular}{|c|c|c|c|c|c|c|c|c|c|}
\hline & \multicolumn{9}{|c|}{ Model Specification } \\
\hline & (1) & (2) & (3) & & (4) & & (8) & (9) & (10) \\
\hline Coefficients: & $\alpha_{b c}=\varphi Q_{b c}$ & $\alpha_{b c}=\varphi Q_{b c}$ & $\begin{array}{l}\alpha_{b}+\alpha_{b c} \\
=\varphi Q_{b c}\end{array}$ & & $\varphi_{c}=\varphi_{c} Q_{t}$ & & $\begin{array}{c}\alpha_{b c}=\varphi Q_{b c} \\
\alpha_{r(s)}+\alpha_{r(s) k}= \\
\pi_{1} Q_{r(s)}\end{array}$ & $\begin{array}{c}\alpha_{\mathrm{bc}}=\varphi Q_{\mathrm{bc}} \\
\alpha_{\mathrm{r}(\mathrm{s})}+\alpha_{\mathrm{r}(\mathrm{s}) \mathrm{k}}= \\
\pi_{1} \mathrm{Q}_{\mathrm{r}(3)}\end{array}$ & $\begin{array}{c}\alpha_{b c}=\varphi Q_{b c} \\
\alpha_{r(s)}+\alpha_{r(s k}= \\
\pi_{1} Q_{r(s)}+\pi_{2} D_{r(s)}\end{array}$ \\
\hline Cohort: & & & & $20 \mathrm{~s}$ & $30 \mathrm{~s}$ & $40 \mathrm{~s}$ & & & \\
\hline $\begin{array}{l}\text { Pupil-Teacher } \\
\text { Ratio }\end{array}$ & $\begin{array}{l}-22.35 \\
(16.53)\end{array}$ & $\begin{array}{c}-28.14 \\
(16.35)\end{array}$ & $\begin{array}{c}-4.54 \\
(6.00)\end{array}$ & $\begin{array}{l}-22.36 \\
(11.13)\end{array}$ & $\begin{array}{l}-10.10 \\
(8.46)\end{array}$ & $\begin{array}{l}34.23 \\
(9.56)\end{array}$ & $\begin{array}{l}-28.14 \\
(20.71)\end{array}$ & $\begin{array}{l}-28.14 \\
(19.96)\end{array}$ & $\begin{array}{l}-28.14 \\
(18.30)\end{array}$ \\
\hline Term Length & $\ldots$ & $\begin{array}{l}17.95 \\
(5.01)\end{array}$ & $\begin{array}{c}9.19 \\
(2.59)\end{array}$ & $\begin{array}{c}7.28 \\
(3.53)\end{array}$ & $\begin{array}{c}2.77 \\
(4.80)\end{array}$ & $\begin{array}{l}30.46 \\
(6.86)\end{array}$ & $\begin{array}{l}17.95 \\
(7.13)\end{array}$ & $\begin{array}{l}17.95 \\
(6.72)\end{array}$ & $\begin{array}{l}17.95 \\
(5.96)\end{array}$ \\
\hline $\begin{array}{l}\text { Relative Teacher } \\
\text { Salary } \\
\text { Demand and } \\
\text { Supply } \\
\text { Aggregates }\end{array}$ & $\ldots$ & $\begin{array}{c}7.41 \\
(2.42)\end{array}$ & $\begin{array}{c}4.99 \\
(0.82)\end{array}$ & $\begin{array}{c}4.39 \\
(0.97)\end{array}$ & $\begin{array}{l}12.46 \\
(1.64)\end{array}$ & $\begin{array}{c}-5.03 \\
(1.65)\end{array}$ & $\begin{array}{c}7.41 \\
(3.21)\end{array}$ & $\begin{array}{c}7.41 \\
(3.07)\end{array}$ & $\begin{array}{c}7.41 \\
(2.78)\end{array}$ \\
\hline reg. avg. PTR-A & $\cdots$ & $\cdots$ & $\cdots$ & $\cdots$ & $\cdots$ & $\cdots$ & $\begin{array}{c}-52.96 \\
(13.64)\end{array}$ & $\begin{array}{c}-12.86 \\
(12.16)\end{array}$ & $\begin{array}{r}-286.72 \\
(28.24)\end{array}$ \\
\hline $\begin{array}{l}\text { reg. avg. Term } \\
\text { Length }\end{array}$ & ... & ... & ... & ... & ... & ... & ... & $\begin{array}{l}59.62 \\
(5.08)\end{array}$ & $\begin{array}{l}108.62 \\
(14.04)\end{array}$ \\
\hline$\% 12$ years & $\ldots$ & ... & ... & $\ldots$ & ... & ... & ... & $\ldots$ & $\begin{array}{l}-1.74 \\
(0.16)\end{array}$ \\
\hline $\begin{array}{l}\% 1-3 \text { years } \\
\text { college }\end{array}$ & ... & $\ldots$ & ... & ... & ... & ... & ... & ... & $\begin{array}{l}-0.50 \\
(0.09)\end{array}$ \\
\hline & ... & $\ldots$ & ... & ... & ... & ... & ... & ... & $\begin{array}{l}-0.58 \\
(0.27)\end{array}$ \\
\hline \% manufacturing & ... & $\cdots$ & ... & ... & $\cdots$ & $\cdots$ & ... & $\cdots$ & $\begin{array}{c}0.30 \\
(0.05)\end{array}$ \\
\hline
\end{tabular}

(1) The number of observations $=1323$ (49 states of birth $\times 9$ regions $\times 3$ cohorts).

(2) The \% of the workforce in the manufacturing industry was computed from the 1980 Census (A Sample) using male and female workers age 18-65. The mean quality within a region of residence was calculated using the 20-29,30-39, and 40-49 birth cohorts.

(3) The pupil-teacher ratio and term length were divided by 100 in the regression. The attendance based pupil-teacher ratio was used. 
TABLE 13

F-Tests for Significance of Region of Birth-Region of Residence of Residence Interactions Both in Intercepts and in Slopes for the Linear Model

\begin{tabular}{|c|c|c|c|c|c|c|c|}
\hline & & \multicolumn{2}{|c|}{1970} & \multicolumn{2}{|c|}{1980} & \multicolumn{2}{|c|}{1990} \\
\hline Birth Cohort & $\begin{array}{l}\text { Test for Region } \\
\text { Interactions: }\end{array}$ & $\theta_{r b}$ & $\alpha_{\mathrm{rb}}$ & $\theta_{\mathrm{rb}}$ & $\alpha_{r b}$ & $\theta_{\mathrm{rb}}$ & $\alpha_{t b}$ \\
\hline 1910-19 & $\begin{array}{l}\text { F Statistic } \\
\text { P-value }\end{array}$ & $\begin{array}{l}1.47 \\
0.01\end{array}$ & $\begin{array}{l}2.20 \\
0.00\end{array}$ & NA & NA & NA & NA \\
\hline $1920-29$ & $\begin{array}{l}\text { F Statistic } \\
\text { P-value }\end{array}$ & $\begin{array}{l}1.96 \\
0.00\end{array}$ & $\begin{array}{l}2.44 \\
0.00\end{array}$ & $\begin{array}{l}1.81 \\
0.00\end{array}$ & $\begin{array}{l}2.25 \\
0.00\end{array}$ & NA & NA \\
\hline 1930-39 & $\begin{array}{l}F \text { Statistic } \\
\text { P-value }\end{array}$ & $\begin{array}{l}1.67 \\
0.00 \\
\end{array}$ & $\begin{array}{l}1.67 \\
0.00 \\
\end{array}$ & $\begin{array}{l}2.40 \\
0.00 \\
\end{array}$ & $\begin{array}{l}2.59 \\
0.00 \\
\end{array}$ & $\begin{array}{l}2.02 \\
0.00 \\
\end{array}$ & $\begin{array}{l}2.51 \\
0.00 \\
\end{array}$ \\
\hline $1940-49$ & $\begin{array}{l}\text { F Statistic } \\
\text { P-value }\end{array}$ & $\begin{array}{l}2.33 \\
0.00\end{array}$ & $\begin{array}{l}1.64 \\
0.00\end{array}$ & $\begin{array}{l}3.06 \\
0.00\end{array}$ & $\begin{array}{l}3.03 \\
0.00\end{array}$ & $\begin{array}{l}3.62 \\
0.00\end{array}$ & $\begin{array}{l}4.65 \\
0.00\end{array}$ \\
\hline $1950-59$ & $\begin{array}{l}\text { F-Statistic } \\
\text { P-value }\end{array}$ & $\mathrm{NA}$ & NA & NA & NA & $\begin{array}{l}6.77 \\
0.00\end{array}$ & $\begin{array}{l}7.15 \\
0.00\end{array}$ \\
\hline
\end{tabular}

Note: $\theta_{\mathrm{rb}}$ is an intercept term and $\alpha_{\mathrm{tb}}$ is a slope term for education. Each of the tests is joint over 64 coefficients. 
Table 14a

1980 Census: The Effect of Schooling Quality on the Return to Education Linear Model with Region of Birth*Region of Residence Interactions

Second Stage Model: Rate of Return $=\alpha+\alpha_{b}+\alpha_{r(s)}+\alpha_{c}+\alpha_{b c}+\alpha_{r(s) c}+\alpha_{r(s) r(b)}+\alpha_{r(s) r(b) c}$

(Eicher-White standard errors in parentheses)

\begin{tabular}{|c|c|c|c|c|c|}
\hline \multirow[b]{3}{*}{ Coefficient Estimates } & \multicolumn{5}{|c|}{ Second Stage Model Restrictions } \\
\hline & (1) & (2) & (3) & (4) & (5) \\
\hline & \multicolumn{4}{|c|}{$\alpha_{b c}+\alpha_{r(b) r(s)}+\alpha_{r(b) r(s) c}=\phi_{r(s)} Q_{b c}+\eta d$} & $\alpha_{b}+\alpha_{b c}+\alpha_{r(b) r(s)}+\alpha_{r(b) r(s) c}=\phi_{r(s)} Q_{b c}+\eta d$ \\
\hline \multicolumn{6}{|c|}{\begin{tabular}{|l|l|l|} 
Pupil-Teacher Ratio & & \\
\end{tabular}} \\
\hline New England & $\begin{array}{c}8.85 \\
(4.52)\end{array}$ & $\ldots$ & $\cdots$ & $\begin{array}{c}7.58 \\
(4.44)\end{array}$ & $\begin{array}{l}15.34 \\
(3.97)\end{array}$ \\
\hline Middle Atlantic & $\begin{array}{l}-7.07 \\
(3.35)\end{array}$ & $\ldots$ & $\ldots$ & $\begin{array}{c}-7.23 \\
(3.40)\end{array}$ & $\begin{array}{c}0.39 \\
(2.55)\end{array}$ \\
\hline Eatit North Central & $\begin{array}{c}-8.22 \\
(3.03)\end{array}$ & $\cdots$ & $\ldots$ & $\begin{array}{l}-6.84 \\
(3.04)\end{array}$ & $\begin{array}{c}1.28 \\
(2.09)\end{array}$ \\
\hline West North Central & $\begin{array}{c}-5.46 \\
(3.47)\end{array}$ & $\cdots$ & $\cdots$ & $\begin{array}{l}-5.18 \\
(3.51)\end{array}$ & $\begin{array}{c}3.89 \\
(2.74)\end{array}$ \\
\hline South Atlantic & $\begin{array}{l}-9.29 \\
(3.18)\end{array}$ & $\cdots$ & $\cdots$ & $\begin{array}{l}-9.30 \\
(3.17)\end{array}$ & $\begin{array}{l}-1.77 \\
(2.17)\end{array}$ \\
\hline East South Central & $\begin{array}{l}-6.65 \\
(3.75)\end{array}$ & $\cdots$ & $\cdots$ & $\begin{array}{l}-6.18 \\
(3.72)\end{array}$ & $\begin{array}{c}1.85 \\
(3.32)\end{array}$ \\
\hline West South Central & $\begin{array}{l}-3.37 \\
(2.94)\end{array}$ & $\cdots$ & $\cdots$ & $\begin{array}{l}-2.75 \\
(2.88)\end{array}$ & $\begin{array}{c}5.60 \\
(2.07)\end{array}$ \\
\hline Mountiun & $\begin{array}{l}-3.88 \\
(3.09)\end{array}$ & $\ldots$ & $\ldots$ & $\begin{array}{c}-2.47 \\
(3.08)\end{array}$ & $\begin{array}{c}6.40 \\
(2.32)\end{array}$ \\
\hline Pacitic & $\begin{array}{l}-6.77 \\
(2.93)\end{array}$ & $\cdots$ & $\cdots$ & $\begin{array}{l}-5.40 \\
(2.93)\end{array}$ & $\begin{array}{c}3.14 \\
(1.77) \\
\end{array}$ \\
\hline \multicolumn{6}{|l|}{ Teacher Salary } \\
\hline New England & $\cdots$ & $\begin{array}{c}2.58 \\
(0.69)\end{array}$ & $\cdots$ & $\begin{array}{c}3.49 \\
(0.63)\end{array}$ & $\begin{array}{c}1.21 \\
(0.59)\end{array}$ \\
\hline Middle Atlantic & $\ldots$ & $\begin{array}{c}2.59 \\
(0.46)\end{array}$ & $\cdots$ & $\begin{array}{c}3.42 \\
(0.49)\end{array}$ & $\begin{array}{c}1.13 \\
(0.37)\end{array}$ \\
\hline East North Central & $\ldots$ & $\begin{array}{c}2.59 \\
(0.42)\end{array}$ & $\cdots$ & $\begin{array}{c}3.06 \\
(0.43)\end{array}$ & $\begin{array}{c}0.74 \\
(0.28)\end{array}$ \\
\hline West North Central & $\cdots$ & $\begin{array}{c}2.55 \\
(0.53)\end{array}$ & $\ldots$ & $\begin{array}{c}3.37 \\
(0.58)\end{array}$ & $\begin{array}{c}1.01 \\
(0.52)\end{array}$ \\
\hline South Atlantic & $\cdots$ & $\begin{array}{c}2.58 \\
(0.42)\end{array}$ & $\ldots$ & $\begin{array}{c}3.38 \\
(0.45)\end{array}$ & $\begin{array}{c}1.06 \\
(0.31)\end{array}$ \\
\hline East South Central & $\cdots$ & $\begin{array}{c}2.60 \\
(0.51)\end{array}$ & $\cdots$ & $\begin{array}{c}3.27 \\
(0.53)\end{array}$ & $\begin{array}{c}0.92 \\
(0.46)\end{array}$ \\
\hline West South Central & $\ldots$ & $\begin{array}{c}2.58 \\
(0.39)\end{array}$ & $\cdots$ & $\begin{array}{c}3.19 \\
(0.42)\end{array}$ & $\begin{array}{c}0.82 \\
(0.34)\end{array}$ \\
\hline Mountain & $\ldots$ & $\begin{array}{c}2.56 \\
(0.46)\end{array}$ & $\ldots$ & $\begin{array}{c}3.03 \\
(0.48)\end{array}$ & $\begin{array}{c}0.67 \\
(0.45)\end{array}$ \\
\hline Pacific & $\cdots$ & $\begin{array}{c}2.57 \\
(0.44)\end{array}$ & $\cdots$ & $\begin{array}{c}3.06 \\
(0.45)\end{array}$ & $\begin{array}{c}0.72 \\
(0.23)\end{array}$ \\
\hline
\end{tabular}


Table $14 a$ continued

1980 Census: The Effect of Schooling Quality on the Return to Education Linear Model with Region of Birth*Region of Residence Interactions

Second Stage Model: Rate of Return $=\alpha+\alpha_{b}+\alpha_{r(s)}+\alpha_{c}+\alpha_{b c}+\alpha_{r(s) c}+\alpha_{r(s) r(b)}+\alpha_{r(s) r(b) c}$ (Eicher-White standard errors in parentheses)

\begin{tabular}{|c|c|c|c|c|c|}
\hline \multirow[b]{3}{*}{ Coefficient Estimates } & \multicolumn{5}{|c|}{ Second Stage Model Restrictions } \\
\hline & (1) & (2) & (3) & (4) & (5) \\
\hline & \multicolumn{4}{|c|}{$\alpha_{b c}+\alpha_{r(b) r(s)}+\alpha_{r(b) r(s) c}=\phi_{r(s)} Q_{b c}+\eta d$} & $\alpha_{b}+\alpha_{b c}+\alpha_{r(b) r(s)}+\alpha_{r(b) r(s) c}=\phi_{r(s)} Q_{b c}+\eta d$ \\
\hline Term Length & & & & & \\
\hline New England & $\ldots$ & $\ldots$ & $\begin{array}{l}-7.51 \\
(2.09)\end{array}$ & $\begin{array}{c}-9.92 \\
(2.03)\end{array}$ & $\begin{array}{l}-5.50 \\
(2.02)\end{array}$ \\
\hline Middle Atlantic & $\ldots$ & $\ldots$ & $\begin{array}{l}-1.58 \\
(1.47)\end{array}$ & $\begin{array}{l}-5.18 \\
(1.49)\end{array}$ & $\begin{array}{c}-0.69 \\
(1.21)\end{array}$ \\
\hline East North Central & $\ldots$ & $\ldots$ & $\begin{array}{c}2.78 \\
(1.32)\end{array}$ & $\begin{array}{l}-0.38 \\
(1.32)\end{array}$ & $\begin{array}{c}4.44 \\
(0.97)\end{array}$ \\
\hline West North Central & $\ldots$ & $\ldots$ & $\begin{array}{c}-2.29 \\
(1.56)\end{array}$ & $\begin{array}{l}-5.58 \\
(1.68)\end{array}$ & $\begin{array}{c}-0.48 \\
(1.48)\end{array}$ \\
\hline South Atlantic & $\ldots$ & ... & $\begin{array}{c}-0.64 \\
(1.11)\end{array}$ & $\begin{array}{l}-4.28 \\
(1.13)\end{array}$ & $\begin{array}{c}0.66 \\
(0.92)\end{array}$ \\
\hline East South Central & $\ldots$ & $\ldots$ & $\begin{array}{l}-0.01 \\
(1.51)\end{array}$ & $\begin{array}{c}-3.26 \\
(1.58)\end{array}$ & $\begin{array}{c}1.90 \\
(1.40)\end{array}$ \\
\hline West South Central & $\cdots$ & $\ldots$ & $\begin{array}{c}-0.45 \\
(1.13)\end{array}$ & $\begin{array}{l}-3.32 \\
(1.11)\end{array}$ & $\begin{array}{c}2.01 \\
(1.05)\end{array}$ \\
\hline Mountiun & $\ldots$ & $\ldots$ & $\begin{array}{l}1.40 \\
(1.46)\end{array}$ & $\begin{array}{c}-1.36 \\
(1.48)\end{array}$ & $\begin{array}{c}3.83 \\
(1.46)\end{array}$ \\
\hline Pacific & $\ldots$ & $\ldots$ & $\begin{array}{c}2.19 \\
(1.17)\end{array}$ & $\begin{array}{c}-0.89 \\
(1.19)\end{array}$ & $\begin{array}{c}4.12 \\
(1.00)\end{array}$ \\
\hline distance & $\begin{array}{c}1.19 \\
(0.15)\end{array}$ & $\begin{array}{c}1.24 \\
(0.14)\end{array}$ & $\begin{array}{l}1.16 \\
(0.15)\end{array}$ & $\begin{array}{c}1.11 \\
(0.15)\end{array}$ & $\begin{array}{c}0.94 \\
(0.17)\end{array}$ \\
\hline distance squared & $\begin{array}{c}-0.22 \\
(0.05) \\
\end{array}$ & $\begin{array}{c}-0.24 \\
(0.05) \\
\end{array}$ & $\begin{array}{c}-0.23 \\
(0.05) \\
\end{array}$ & $\begin{array}{c}-0.21 \\
(0.05) \\
\end{array}$ & $\begin{array}{l}-0.18 \\
(0.06)\end{array}$ \\
\hline
\end{tabular}

(1) The number of observations $=1343$ (49 states of birth $\times 9$ regions $\times 3$ cohorts).

12) The $\%$ of the workforce in the manufacturing industry was computed from the 1980 Census using male and female workers age 18-65. The mean quality within a region of residence was calculated using the $20-29,30-39$, and $40-49$ cohurts.

13) The utnitted eduction category is $<12$ years.

(1) The pupil-teacher rafio and term length were divided by 100 in the regression. The attendance based pupil-teacher ra(16 was used.

(5) Distance is measured in thousands of miles. 
Table 15

F-Tests for the Restriction that Quality Effects are Equal Across Regions of Residence in the Linear Second Stage Model with Interactions

\begin{tabular}{|c|c|c|c|c|}
\hline \multicolumn{5}{|c|}{ Census Year } \\
\hline Quality Variable & & $\mathbf{1 9 7 0}$ & $\mathbf{1 9 8 0}$ & $\mathbf{1 9 9 0}$ \\
\hline & & & & \\
Pupil-Teacher Ratio & F-statistic & 4.72 & 4.34 & 3.86 \\
& p-value & 0.0001 & 0.0001 & 0.0002 \\
Term Length & F-statistic & 2.77 & 4.07 & 3.03 \\
& p-value & 0.0048 & 0.0001 & 0.0021 \\
Teacher Salary & F-statistic & 0.48 & 0.20 & 0.14 \\
& p-value & $\mathbf{0 . 8 7 3 7}$ & 0.9913 & 0.9975 \\
\hline
\end{tabular}

(1) This tests are conducted on the second stage equation relating the total return to education to the quality measures. For the 1970 Census regression, $n=1764$, and for the 1980 and 1990 Census regressions, $n=$ 1323. The test is conducted on the form of the model that contains an intercept, cohort dummies, region of residence and state of birth indicators, region of residence interacted with cohort indicators, distance between region of residence and region of birth, and indicators for region of residence interacted with each of the quality variables. Each test considers eight restrictions on the model. 
TABLE 16a

The Effect of Quality on Educational Attainment

1980 Census Data

$\left[\ln \left(N_{\mathrm{Bd}_{\text {. Leve }} / \text { Population }}\right)=\mathrm{a}+\ln \left(\mathrm{Q}_{\mathrm{bc}}\right) \boldsymbol{\beta}_{\mathrm{c}}\right]$, Standard errors in parentheses

\begin{tabular}{|c|c|c|c|c|}
\hline \multicolumn{5}{|c|}{ Education Level: College Graduates } \\
\hline $\begin{array}{l}\text { Birth } \\
\text { Cohort }\end{array}$ & Model & PTR-A & $\begin{array}{l}\text { Teacher } \\
\text { Salary }\end{array}$ & Term Length \\
\hline $1920 s$ & $\begin{array}{l}\text { (1) } \\
\text { (2) }\end{array}$ & $\begin{array}{l}-0.42 \\
(0.20) \\
-0.44 \\
(0.18) \\
\end{array}$ & $\begin{array}{c}\cdots \\
1.08 \\
(0.74) \\
\end{array}$ & $\begin{array}{c}\cdots \\
0.36 \\
(0.13) \\
\end{array}$ \\
\hline 1930s & $\begin{array}{l}\text { (1) } \\
(2)\end{array}$ & $\begin{array}{c}-0.59 \\
(0.22) \\
-0.59 \\
(0.18) \\
\end{array}$ & $\begin{array}{c}\cdots \\
2.83 \\
(0.98) \\
\end{array}$ & $\begin{array}{c}\ldots \\
0.52 \\
(0.15)\end{array}$ \\
\hline $1940 s$ & $\begin{array}{l}\text { (1) } \\
(2)\end{array}$ & $\begin{array}{c}-0.73 \\
(0.22) \\
-0.75 \\
(0.18) \\
\end{array}$ & $\begin{array}{c}\ldots \\
2.38 \\
(1.19) \\
\end{array}$ & $\begin{array}{c}\ldots \\
0.73 \\
(0.16) \\
\end{array}$ \\
\hline
\end{tabular}

\begin{tabular}{l|c|c|c|c}
\hline \hline \multicolumn{5}{c}{ Education Level: High School Graduates without College Degrees } \\
\hline \hline $1920 \mathrm{~s}$ & $(1)$ & -0.34 & $\ldots$ & $\ldots$ \\
& & $(0.14)$ & & \\
& $(2)$ & -0.34 & 0.96 & 0.16 \\
& & $(0.13)$ & $(0.53)$ & $(0.09)$ \\
\hline $1930 \mathrm{~s}$ & $(1)$ & -0.11 & $\ldots$ & $\ldots$ \\
& & $(0.07)$ & & \\
& $(2)$ & -0.10 & 0.61 & -0.01 \\
& & $(0.07)$ & $(0.36)$ & $(0.05)$ \\
\hline $1940 \mathrm{~s}$ & $(1)$ & -0.02 & $\ldots$ & $\ldots$ \\
& & $(0.07)$ & & -0.14 \\
& $(2)$ & -0.01 & -0.30 & $(0.06)$ \\
\hline
\end{tabular}

\begin{tabular}{l|c|c|c|c}
\hline \multicolumn{5}{|c}{ Education Level: High School Dropouts } \\
\hline \hline $1920 \mathrm{~s}$ & $(1)$ & 0.67 & $\ldots$ & $\ldots$ \\
& & $(0.28)$ & & \\
& $(2)$ & 0.70 & -1.60 & -0.44 \\
& & $(0.26)$ & $(1.04)$ & $(0.18)$ \\
\hline $1930 \mathrm{~s}$ & $(1)$ & 0.78 & $\ldots$ & $\ldots$ \\
& & $(0.32)$ & & \\
& $(2)$ & 0.77 & -3.77 & -0.61 \\
& & $(0.28)$ & $(1.51)$ & $(0.23)$ \\
\hline $1940 \mathrm{~s}$ & $(1)$ & 1.50 & $\ldots$ & $\ldots$ \\
& & $(0.46)$ & & -1.09 \\
& $(2)$ & 1.53 & -3.43 & $(0.37)$ \\
\hline
\end{tabular}

(1) PTR-A refers to the attendance based pupil-teacher ratio.

(2) The highschool graduate category includes men with some college

(3) The dependent variable is the log of the proportion of people in each education category. The estimated coefficients give the percentage change in the proportion of the state's population with a given education level a one percent change in the quality measure. 
TABLE 16b

The Effect of Quality on Educational Attainment

1970 Census Data

$\left[\ln \left(N_{\mathrm{Bd}_{\text {Leve }}} /\right.\right.$ Population $\left.)=\mathrm{a}+\ln \left(\mathrm{Q}_{\mathrm{bc}}\right) \mathrm{B}_{\mathrm{c}}\right]$, Standard errors in parentheses

\begin{tabular}{l|c|c|c|c}
\hline \hline \multicolumn{5}{c|}{ Education Level: College Graduates } \\
\hline Bohort & Model & PTR-A & $\begin{array}{c}\text { Teacher } \\
\text { Salary }\end{array}$ & Term Length \\
\hline 1910s & $(1)$ & -0.56 & $\ldots$ & $\ldots$ \\
& $(2)$ & -0.61 & 1.36 & 0.39 \\
& $(1)$ & $(0.20)$ & $(0.50)$ & $(0.16)$ \\
\hline $1920 s$ & $(2)$ & $(0.24)$ & $\ldots$ & $\ldots$ \\
& $(1)$ & $(0.21)$ & 1.97 & 0.32 \\
& & -0.79 & $(0.86)$ & $(0.15)$ \\
\hline $1930 \mathrm{~s}$ & $(2)$ & $-0.25)$ & $\ldots$ & $\ldots$ \\
& & $(0.21)$ & 3.01 & 0.58 \\
& $(1)$ & -0.92 & $(1.11)$ & $(0.17)$ \\
\hline $1940 s$ & $(2)$ & -0.92 & $\ldots$ & $\ldots$ \\
& & $(0.21)$ & 3.03 & 0.67 \\
& & $(1.41)$ & $(0.18)$ \\
\hline \hline
\end{tabular}

Education Level: High School Graduates without College Degrees

\begin{tabular}{|c|c|c|c|c|}
\hline $1910 s$ & $\begin{array}{l}\text { (1) } \\
(2)\end{array}$ & $\begin{array}{c}-0.51 \\
(0.20) \\
-0.54 \\
(0.17) \\
\end{array}$ & $\begin{array}{c}\ldots \\
1.36 \\
(0.43) \\
\end{array}$ & $\begin{array}{c}\cdots \\
0.30 \\
(0.14) \\
\end{array}$ \\
\hline $1920 \mathrm{~s}$ & $\begin{array}{l}\text { (1) } \\
(2)\end{array}$ & $\begin{array}{c}-0.38 \\
(0.16) \\
-0.39 \\
(0.15) \\
\end{array}$ & $\begin{array}{c}\cdots \\
0.93 \\
(0.61) \\
\end{array}$ & $\begin{array}{c}\cdots \\
0.22 \\
(0.10)\end{array}$ \\
\hline $1930 \mathrm{~s}$ & $\begin{array}{l}\text { (1) } \\
\text { (2) }\end{array}$ & $\begin{array}{c}-0.20 \\
(0.09) \\
-0.18 \\
(0.09) \\
\end{array}$ & $\begin{array}{c}\ldots \\
0.88 \\
(0.48) \\
\end{array}$ & $\begin{array}{c}\ldots \\
0.05 \\
(0.07) \\
\end{array}$ \\
\hline 1940s & $\begin{array}{l}\text { (1) } \\
(2)\end{array}$ & $\begin{array}{c}-0.21 \\
(0.08) \\
-0.21 \\
(0.09)\end{array}$ & $\begin{array}{c}\ldots \\
0.35 \\
(0.57)\end{array}$ & $\begin{array}{c}\cdots \\
0.10 \\
(0.07) \\
\end{array}$ \\
\hline \multicolumn{5}{|c|}{ Education Level: High School Dropouts } \\
\hline $1910 \mathrm{~s}$ & $\begin{array}{l}\text { (1) } \\
(2)\end{array}$ & $\begin{array}{c}0.51 \\
(0.22) \\
0.57 \\
(0.19)\end{array}$ & $\begin{array}{c}\ldots \\
-1.11 \\
(0.47)\end{array}$ & $\begin{array}{c}\cdots \\
-0.40 \\
(0.15) \\
\end{array}$ \\
\hline $1920 \mathrm{~s}$ & $\begin{array}{l}\text { (1) } \\
\text { (2) }\end{array}$ & $\begin{array}{c}0.57 \\
(0.26) \\
0.59 \\
(0.24) \\
\end{array}$ & $\begin{array}{c}\cdots \\
-1.47 \\
(0.97) \\
\end{array}$ & $\begin{array}{c}\cdots \\
-0.39 \\
(0.17) \\
\end{array}$ \\
\hline $1930 \mathrm{~s}$ & $\begin{array}{l}\text { (1) } \\
\text { (2) }\end{array}$ & $\begin{array}{c}0.83 \\
(0.29) \\
0.82 \\
(0.26)\end{array}$ & $\begin{array}{c}\cdots \\
-3.17 \\
(1.41) \\
\end{array}$ & $\begin{array}{c}\ldots \\
-0.52 \\
(0.21) \\
\end{array}$ \\
\hline $1940 \mathrm{~s}$ & $\begin{array}{l}\text { (1) } \\
\text { (2) }\end{array}$ & $\begin{array}{c}1.35 \\
(0.38) \\
1.35 \\
(0.36) \\
\end{array}$ & $\begin{array}{c}\cdots \\
-3.40 \\
(2.35) \\
\end{array}$ & $\begin{array}{c}\ldots \\
-0.87 \\
(0.31) \\
\end{array}$ \\
\hline
\end{tabular}


TABLE 16c

The Efrect of Quality on Educational Attainment

1980 Census Data

$\left[\ln \left(\mathrm{N}_{\mathrm{Ed} \text {. Lever }} /\right.\right.$ Population $\left.)=\mathrm{a}+\ln \left(\mathrm{Q}_{\mathrm{bc}}\right) \beta_{\mathrm{c}}\right]$, Standard errors in parentheses

\begin{tabular}{l|c|c|c|c}
\hline \multicolumn{5}{|c|}{ Education Level: College Graduates } \\
\hline $\begin{array}{l}\text { Birth } \\
\text { Cohort }\end{array}$ & Model & PTR-A & $\begin{array}{c}\text { Teacher } \\
\text { Salary }\end{array}$ & Term Length \\
\hline \hline 1930s & $(1)$ & -0.62 & $\ldots$ & $\ldots$ \\
& $(2)$ & $(0.22)$ & & $\ldots .64$ \\
& & $(0.17)$ & $(0.92)$ & 0.62 \\
& $(1)$ & -0.80 & $\ldots$ & $\ldots$ \\
\hline 1940s & $(2)$ & -0.83 & 2.34 & 0.78 \\
& & $(0.18)$ & $(1.20)$ & $(0.16)$ \\
\hline $1950 s$ & $(1)$ & -0.94 & $\ldots$ & $\ldots$ \\
& & $(0.30)$ & & 0.78 \\
& $(2)$ & -0.79 & 7.20 & $(0.17)$ \\
\hline
\end{tabular}

\begin{tabular}{l|c|c|c|c}
\hline \hline \multicolumn{4}{c}{ Education Level: High School Graduates without College Degrees } \\
\hline 1930s & $(1)$ & -0.07 & $\ldots$ & $\ldots$ \\
& & $(0.06)$ & & \\
& $(2)$ & -0.06 & 0.63 & 0.02 \\
& & $(0.06)$ & $(0.34)$ & $(0.05)$ \\
\hline $1940 \mathrm{~s}$ & $(1)$ & 0.07 & $\ldots$ & $\ldots$ \\
& & $(0.07)$ & & \\
& $(2)$ & 0.07 & -0.55 & -0.14 \\
& & $(0.07)$ & $(0.47)$ & $(0.06)$ \\
\hline $1950 \mathrm{~s}$ & $(1)$ & 0.09 & $\ldots$ & $\ldots$ \\
& & $(0.11)$ & & \\
& $(2)$ & 0.06 & -1.83 & -0.20 \\
& & $(0.096)$ & $(0.82)$ & $(0.07)$ \\
\hline
\end{tabular}

\begin{tabular}{l|c|c|c|c}
\hline \hline & \multicolumn{5}{|c}{ Education Level: High School Dropouts } \\
\hline \hline $1930 \mathrm{~s}$ & $(1)$ & 0.88 & $\ldots$ & $\ldots$ \\
& & $(0.42)$ & & \\
& $(2)$ & 0.88 & -4.87 & -0.90 \\
& & $(0.37)$ & $(1.96)$ & $(0.29)$ \\
\hline $1940 \mathrm{~s}$ & $(1)$ & 1.59 & $\ldots$ & $\ldots$ \\
& & $(0.58)$ & $\ldots$ & -1.27 \\
& $(2)$ & 1.63 & -3.93 & $(0.47)$ \\
\hline $1950 \mathrm{~s}$ & $(1)$ & $(0.55)$ & $(3.61)$ & $\ldots$ \\
& & $(0.75)$ & $\ldots$ & -1.07 \\
& $(2)$ & 2.45 & -10.89 & $(0.52)$ \\
\hline
\end{tabular}

(1) PTR-A refers to the atteodance based pupil-teacter ratio.

(2) The highschool graduate category includes men with some colloge

(3) The dependent variable is the $\log$ of the proportion of people in each education calegory. The estimated coefficients give the percentage change in the proportion of the state's population with a given education level 
Figure 1(a): Trend in Average Schooling Quality Over Time

U.S. Average Pupil-Teacher Ratios

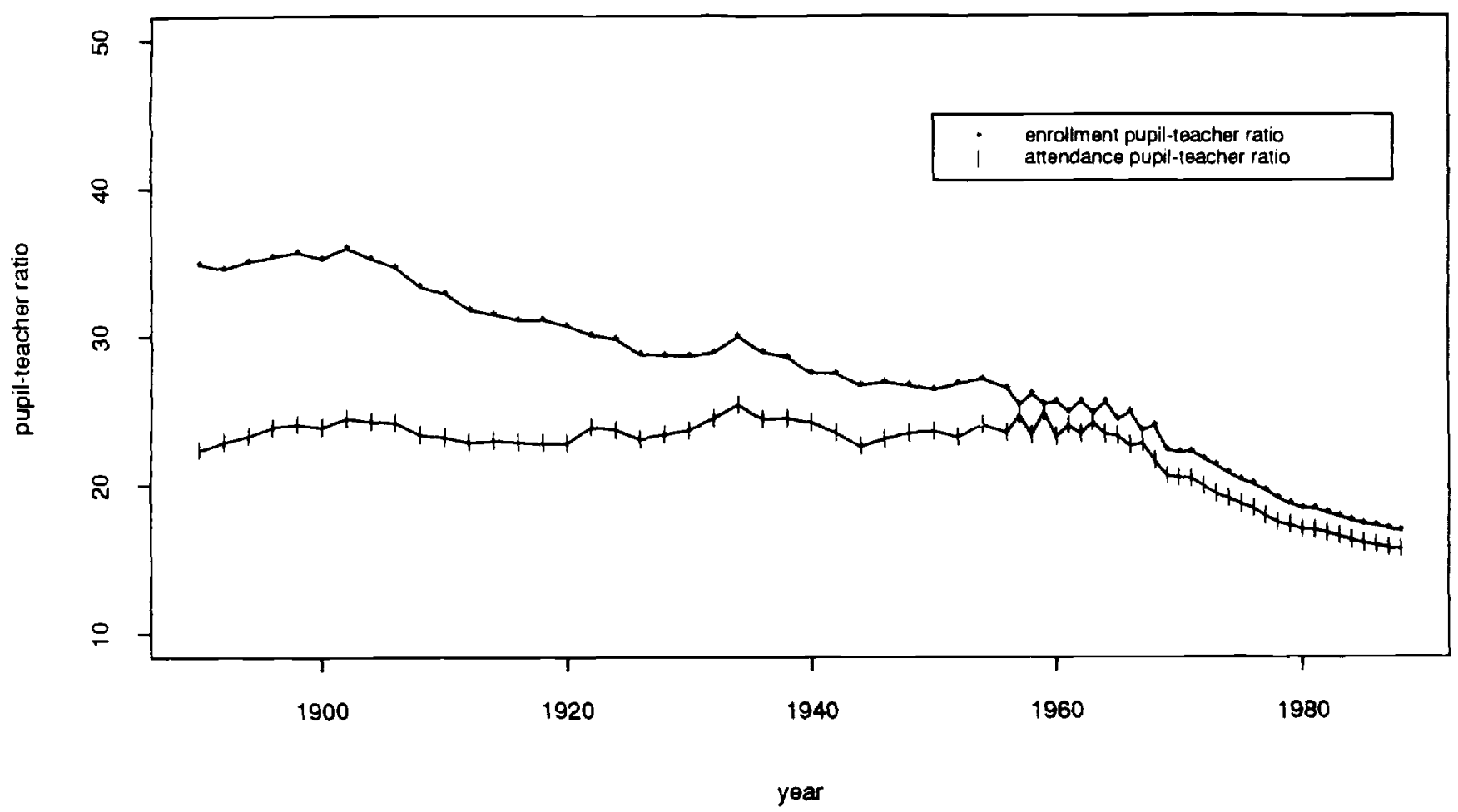

Southern Average Pupil-Teacher Ratios

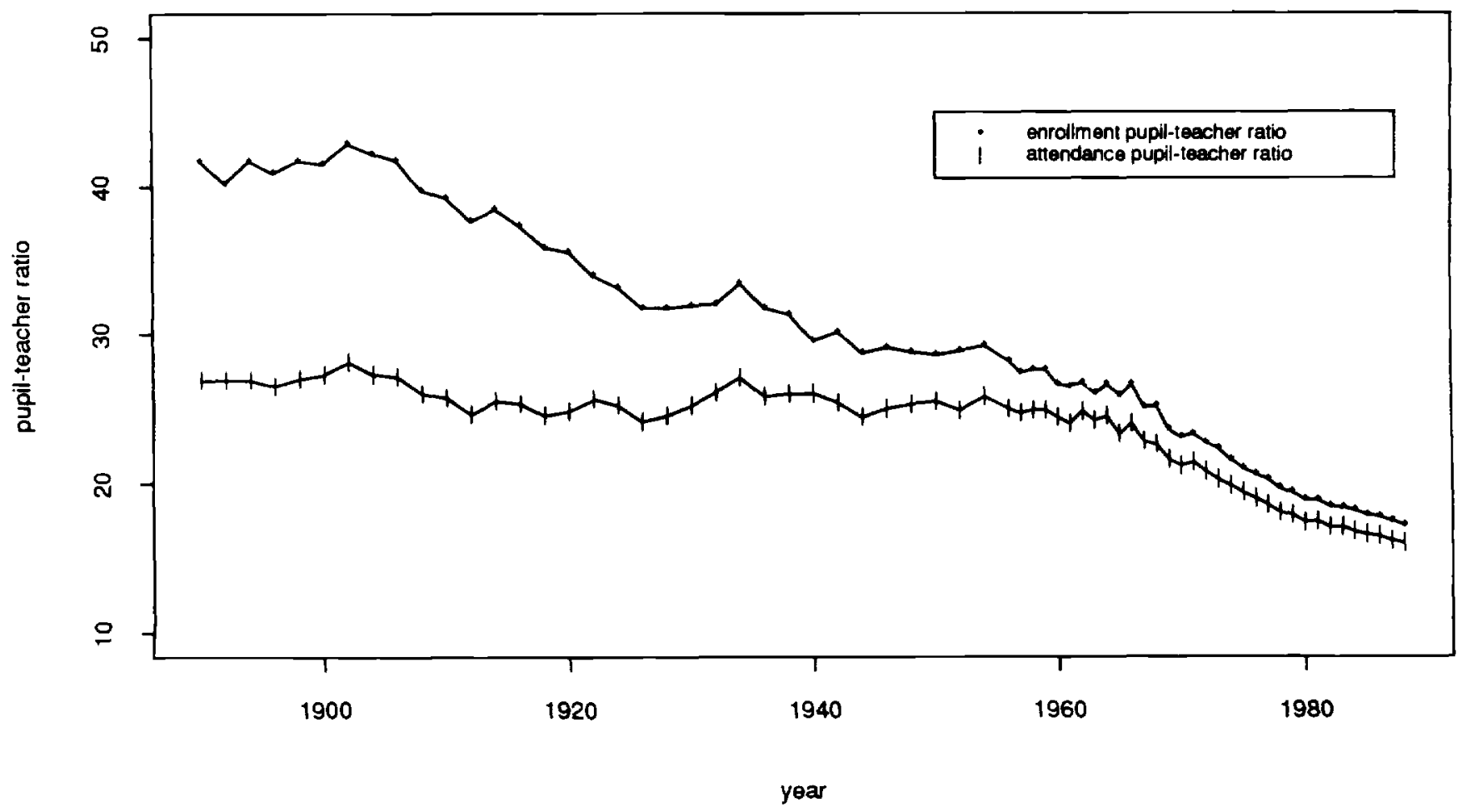


Figure 1(b): Convergence in Schooling Quality Over Time

Variance in Pupil-Teacher Ratios Across U.S. States

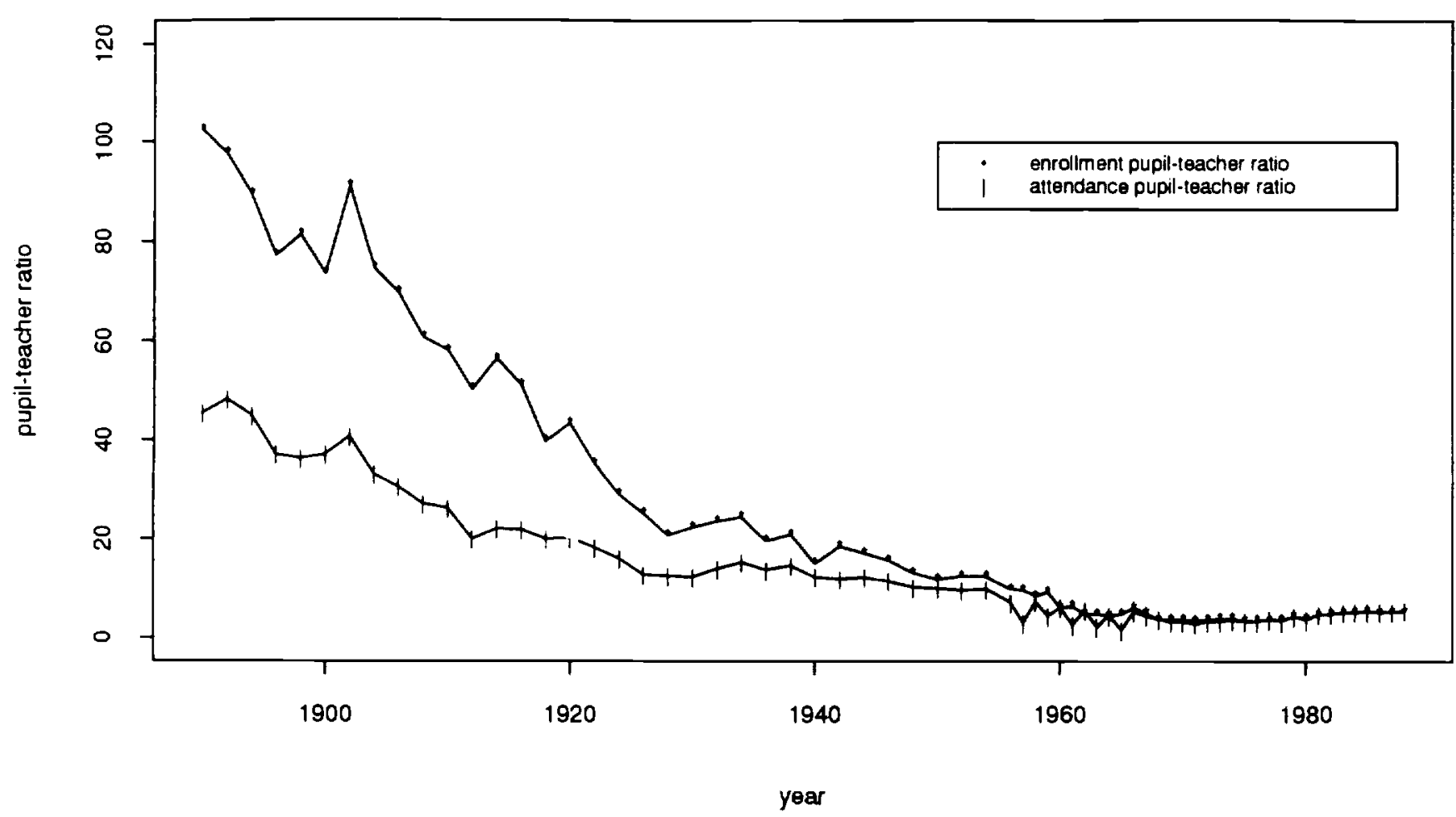

Variance in Pupil-Teacher Ratios Across Southern States

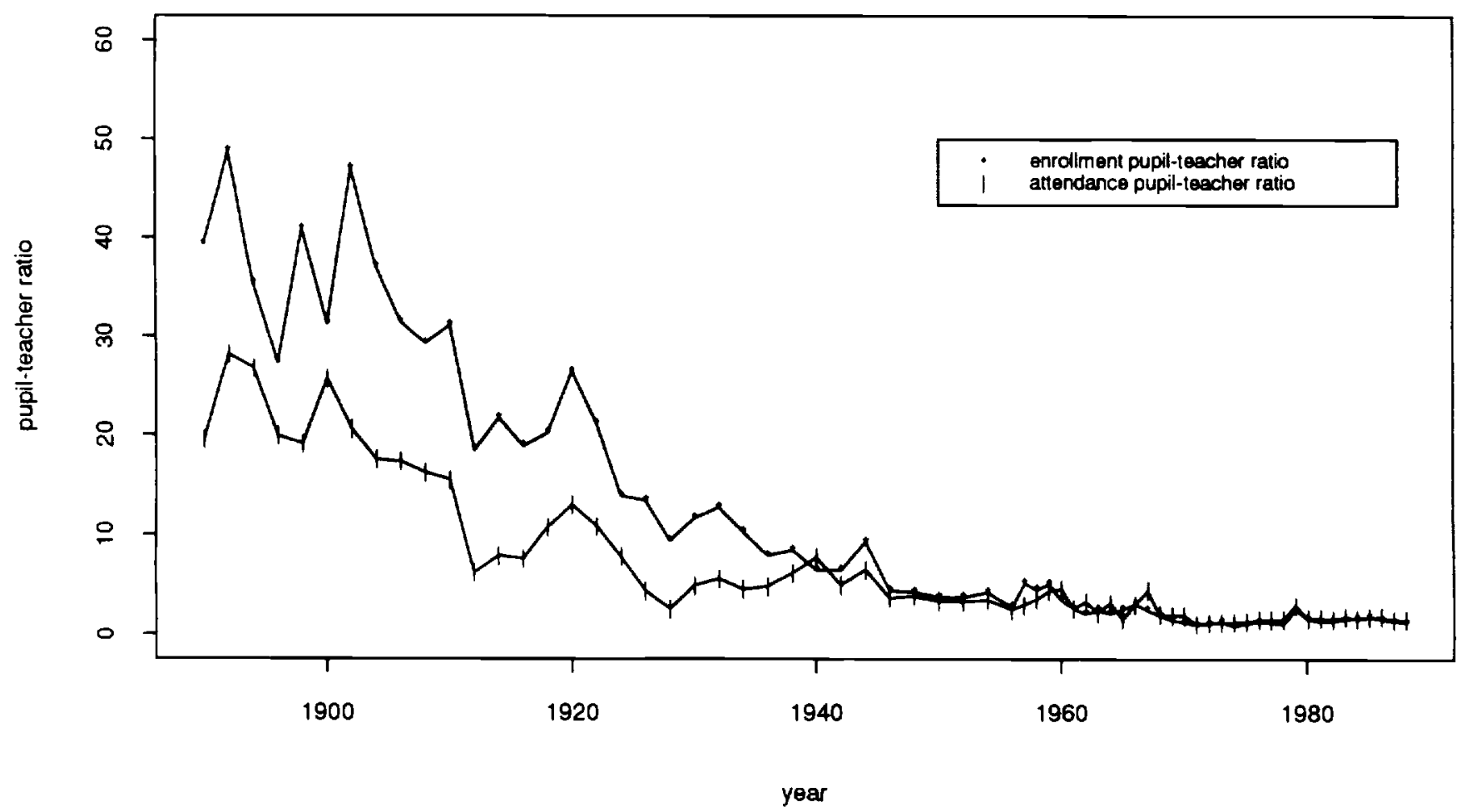


Figure 3: Evidence of Sheepskin Effects in the Return to Education, 1980 Census, 1930-39 Cohort

Figure 3(a): 1980 Census, 1930-39 Cohort, 8th Grade Sheepskin Effects

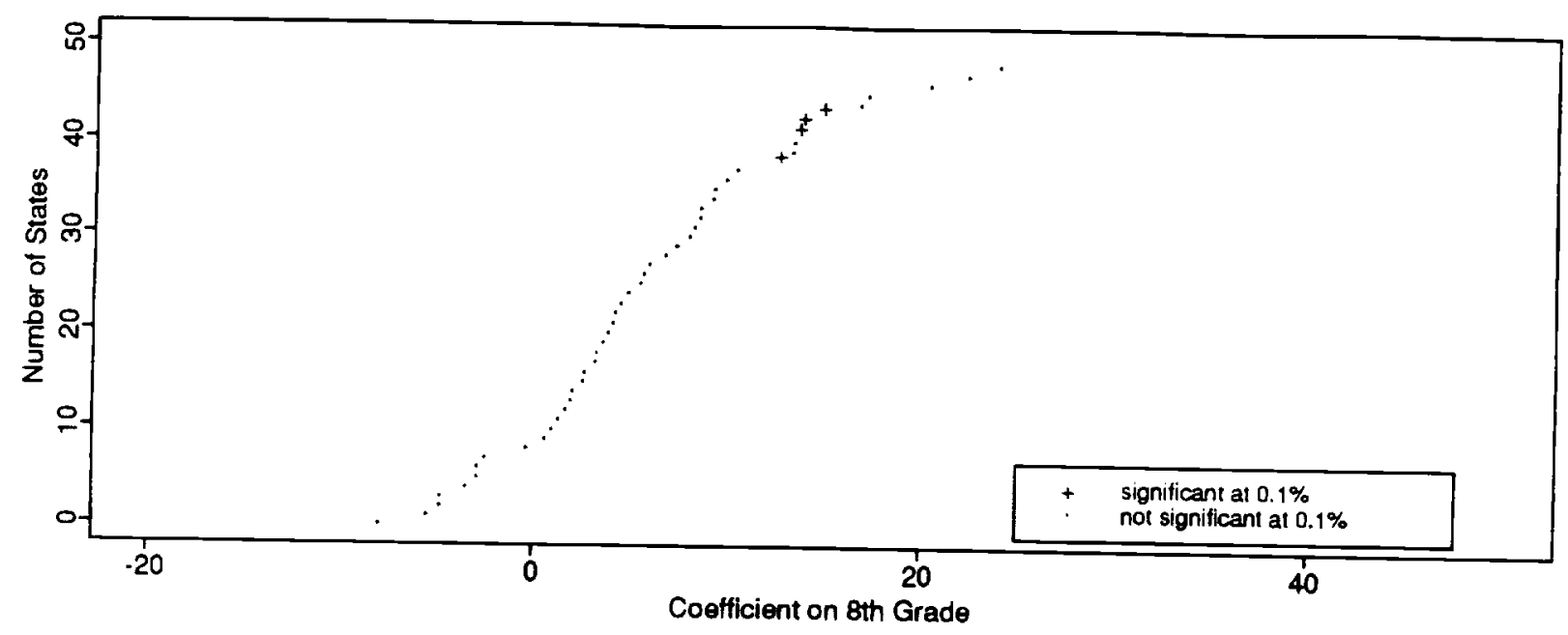

Figure 3(b): 1980 Census, 1930-39 Cohort, 12th Grade Sheepskin Effects

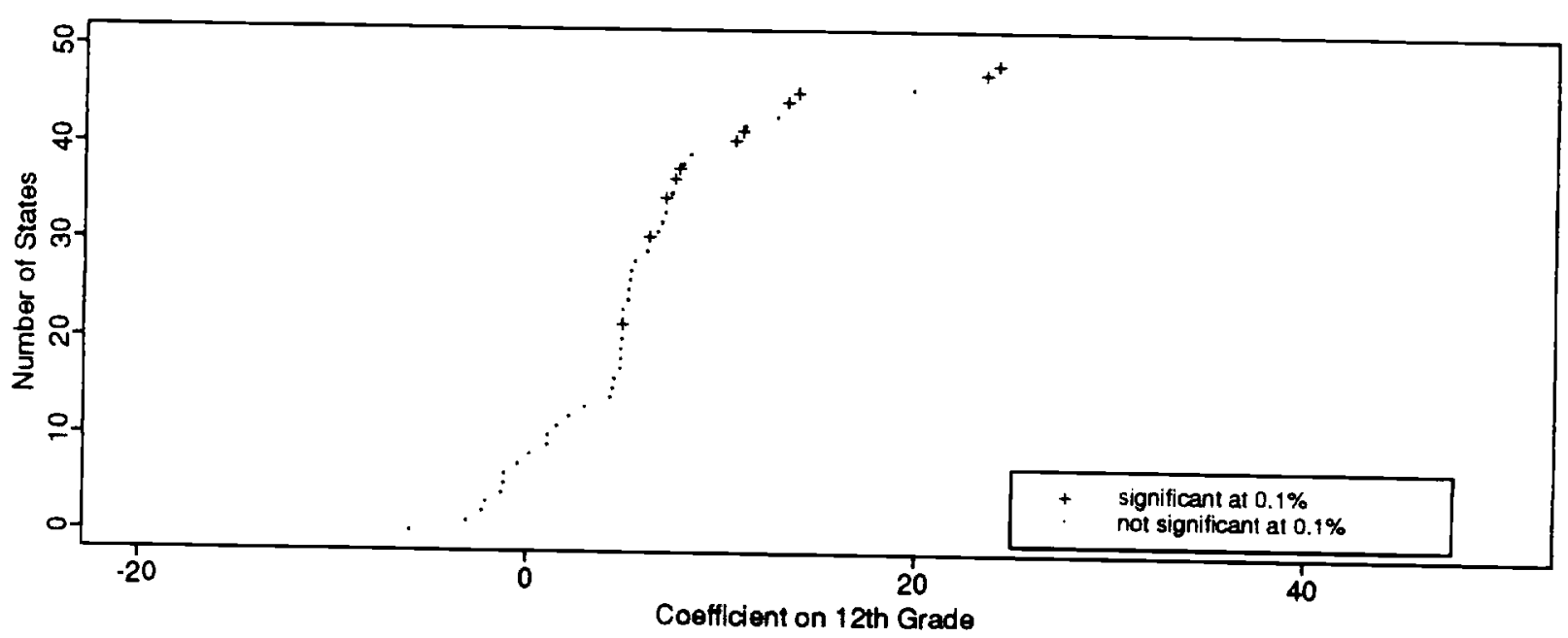

Figure 3(c): 1980 Census, 1930-39 Cohort, 16th Grade Sheepskin Effects

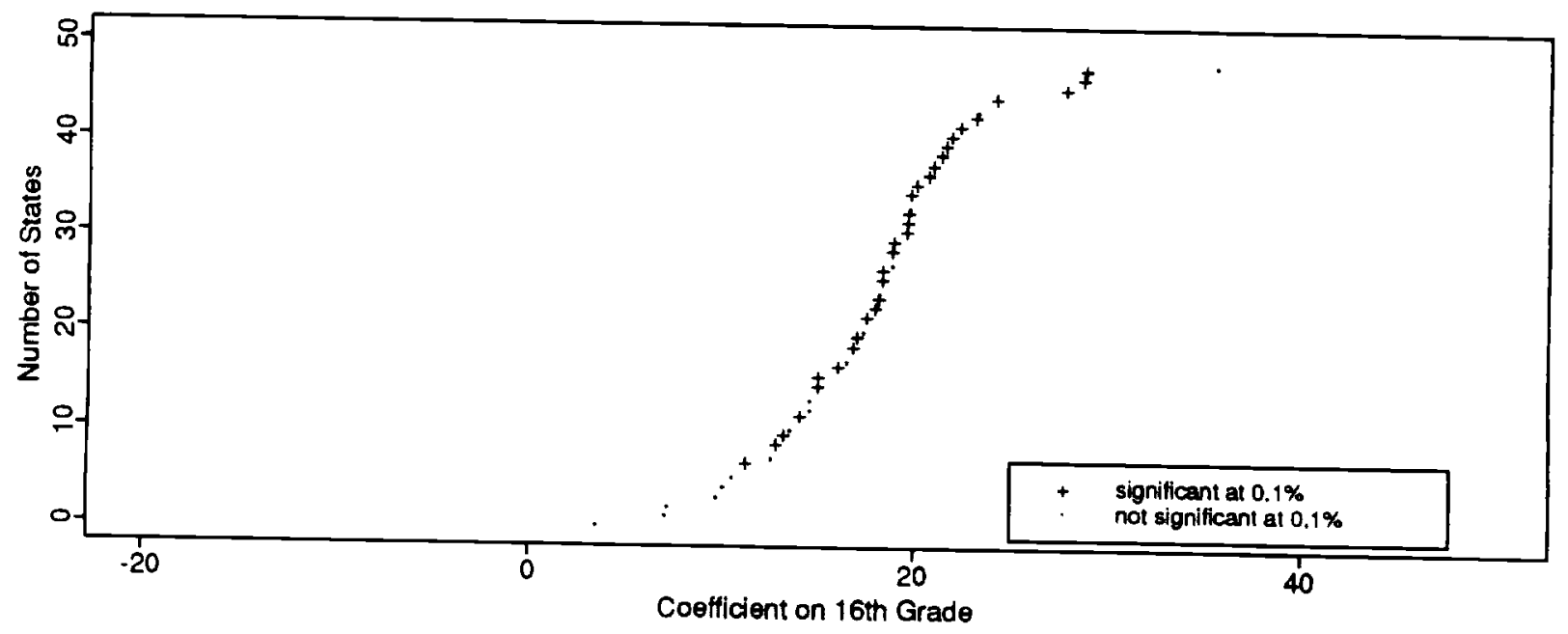


Figure 4: Plots of Estimated Education Returns for Four States , 1980 Census, Cohort 1930-39
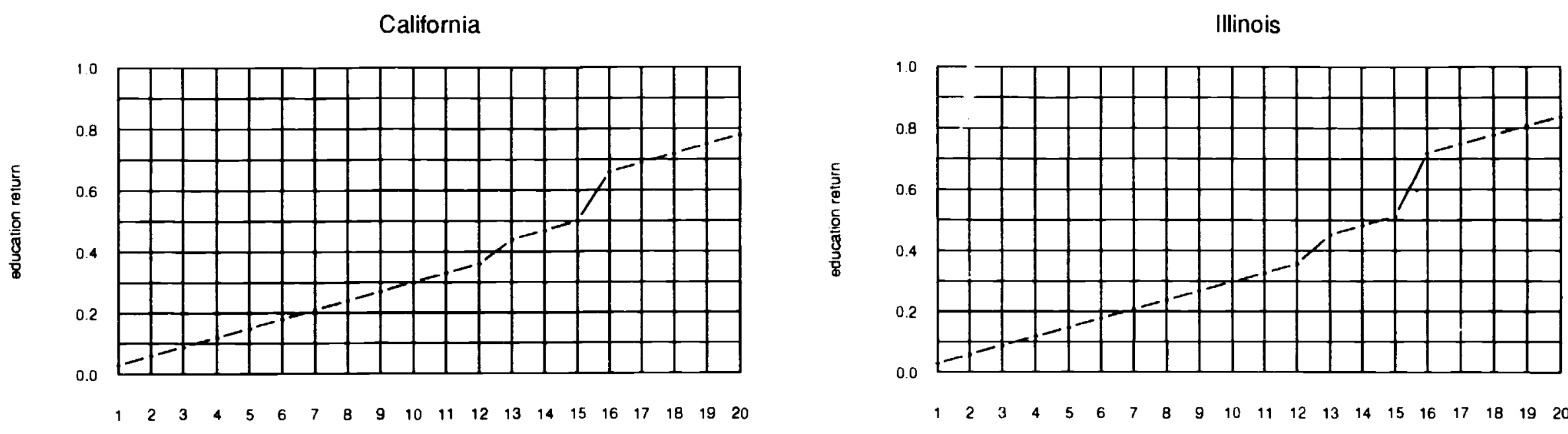

years of education

years of education
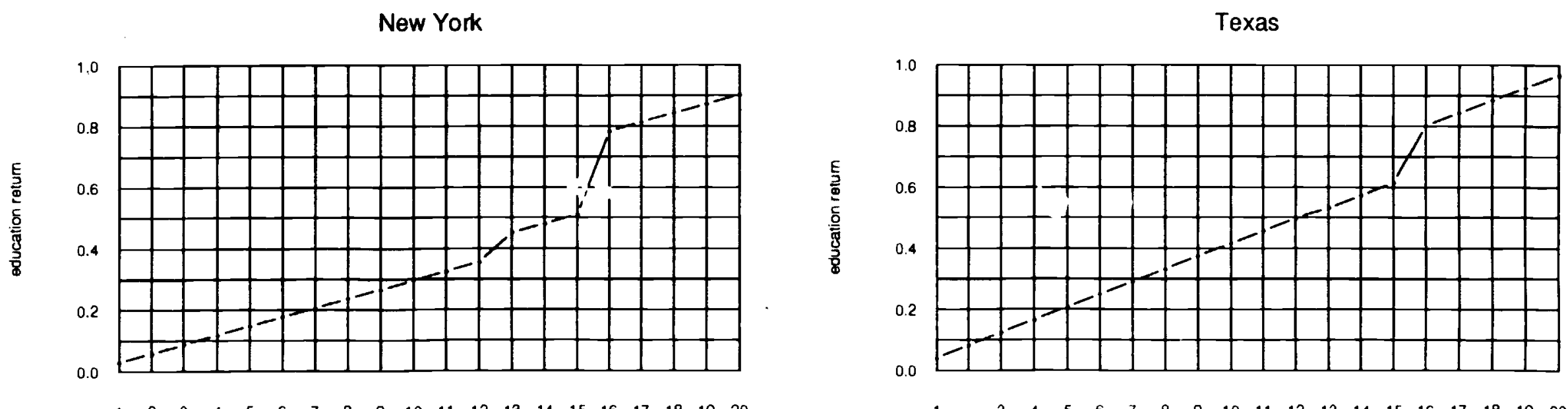

years of education

years of education 


\section{Appendix A: Description of the Analysis Samples}

\section{Description of the Census Data}

Our samples are taken from the 1970, 1980, and 1990 Censuses. The 1970 sample is taken from two one percent Public-Use A samples: the 1 percent State sample (5 percent form) and the 1 percent State sample (15 percent form). It is a self-weighting sample of 2 percent of the population. The 1980 Census and the 1990 Census samples are both 5 percent Public-Use A samples. The 1980 Census sample is self-weighted, but the 1990 sample is not. Therefore, for 1990 , our regressions take into account the weight of each individual in the sample.

To maintain comparability of our empirical results with those of Card and Krueger, we impose identical restrictions on our 1980 sample. To the extent possible, we construct the 1970 and 1990 extractions in the same way. The 1970 Census reports the number of weeks worked in intervals, whereas the 1980 and 1990 Censuses report integer amounts. To get a point estimate for the number of weeks worked in 1970, we calculate the mean number of weeks worked in 1980 within the 1970 intervals and impute these interval means for individuals in the 1970 sample. Point estimates of annual earnings are computed by assigning to individuals the midpoint of their earnings interval. Table A.1 summarizes the full set of restrictions for each of the three Census samples.

Table A.1

Summary of Sample Restrictions

\begin{tabular}{|c|c|}
\hline Sex: & Male \\
\hline Race: & White \\
\hline Place of Birth: & 48 Mainland states and District of Columbia \\
\hline Place of Residence: & $\begin{array}{l}\text { Living in any one of the } 50 \text { states or DC as } \\
\text { of the Census Year. }\end{array}$ \\
\hline \multirow{3}{*}{$\begin{array}{l}\text { Wage/Salary: } \\
\text { (note: } 1970 \text { and } 1990 \text { Censuses' } \\
\text { salary ranges are equal to the } 1980 \\
\text { range adjusted by the appropriate } \\
\text { years' CPI) }\end{array}$} & $\begin{array}{l}1970 \text { Census: Annual } 1969 \text { wage or salary } \\
\text { income of at least } \$ 51 \text { and weekly wage or } \\
\text { salary falling in the range } \$ 18-\$ 1264 \text {. }\end{array}$ \\
\hline & $\begin{array}{l}1980 \text { Census: Annual } 1979 \text { wage or salary } \\
\text { income of at least } \$ 101 \text { and weekly average } \\
\text { wage or salary of } \$ 26-\$ 2500 \text {. }\end{array}$ \\
\hline & $\begin{array}{l}1990 \text { Census: Annual } 1989 \text { wage or salary } \\
\text { income of at least } \$ 173 \text { and average weekly } \\
\text { wage or salary of } \$ 60-\$ 4270\end{array}$ \\
\hline Other Exclusions: & $\begin{array}{l}\text { Individuals with imputed information on } \\
\text { age, race, sex, education, weeks worked, or } \\
\text { income are excluded. Also, individuals who } \\
\text { have not worked at least one week are } \\
\text { excluded. }\end{array}$ \\
\hline
\end{tabular}


Each Census sample is divided into ten year birth cohorts. The year of birth for each individual is determined from information on age and quarter of birth. The sample sizes for each of the birth cohorts is given in Table A.2.

TABLE A.2

Sample Sizes for Birth Cohorts

\begin{tabular}{|c|c|c|c|}
\hline Birth Cohort & 1970 Census & 1980 Census & 1990 Census \\
\hline $1910-19$ & 119894 & NA & NA \\
$1920-29$ & 152245 & 277601 & NA \\
$1930-39$ & 148281 & 302941 & 239373 \\
$1940-49$ & 193808 & 447691 & 418335 \\
$1950-59$ & NA & NA & 571808 \\
\hline
\end{tabular}

Regression Variables

The log weekly wage variable used in the regressions is constructed by dividing the annual wage and salary income by the number of weeks worked. Number of weeks worked is reported directly in the 1980 and 1990 Censuses, but not in the 1970 Census. In 1970, number of weeks worked is reported by category: 0-13 weeks, 14-26, 27-39, $40-47,48-49$, and 50-52 weeks. To arrive at a single number for weeks worked, we calculate the distribution of weeks worked in each of these categories by age, race, and education level using the 1980 Census data. We then impute the mean number of weeks worked for each category in 1980 to the 1970 data.

The experience variable refers to "potential" experience, calculated by the difference, age - years of schooling - 6 . Information on SMSA and marital status variables are available in each Census year's documentation.

Years of education is reported differently in the three Census samples we use. In 1970 and 1980, the Census reports the highest grade completed. In 1990, the Census reports categories of education for first through fourth grade and fifth through eighth grade, and then reports the highest grade completed for nineth through twelfth grades (12 years of school with no degree reported separately from high school graduation). For high school and beyond, the Census then reports only the degree obtained. In order to be comparable to the other two Census sample, we impute the number of years of education associated with each level and degree. For twelve years of school with and without a high school degree, we assign 12 years. For both some college but no degree and an associate (academic or occupational) degree we assign 14 years of school. If a B.A. is reported, we assign 16 years of school. For professional degrees we assign 17 years, and for masters degrees and beyond, including doctoral degrees, we assign 18 years of school.

All of the school quality variables we use in the regressions are described in Appendix B, along with the source of the data. 
This study draws upon state-level data ${ }^{1}$ quantifying three broad aspects of quality for full-time public elementary and secondary day schools (grades K-12): average term length, average annual instructional staff salary, and pupil-teacher ratios. Since our empirical study uses the same quality measures as Card and Krueger's (1992b), we will note the differences in the definitions of our variables from theirs.

Data on average term length and average annual instructional staff salary from 1906 to 1958 comes from the Federal Biennial Survey of Education. From 1960 through 1980, the data was taken from the Digest of Education Statistics (published by the National Center for Education Statistics), and also from individual state education annual or biennial reports. Average term length is defined as "the average number of days in the school term (full-time public elementary and secondary schools)." Prior to 1968, when Southern schools were segregated, Card and Krueger use an average term length measure based on aggregate data including both white and black schools for all states. For pre1968 data in the southern states we use instead term length based on segregated white schools, when available, and the aggregate measure for nonsouthern states. For some early years, the segregated measure was unavailable, in which case we imputed white term length from the aggregate measure. ${ }^{2}$

Average annual instructional staff salary is defined as "the average annual salary per member of the instructional staff (full-time public elementary and secondary schools)." Because of the lack of consistent regional salary deflators over time, we use "relative" teacher salary in our analysis. State-level average instructional staff salaries are divided by the regional average salary. Our relative teacher salary measure differs from that used by Card and Krueger, who use the wages paid to federal highway road laborers and social security wages as relative wages indices. For 1920-1938, they use the wage paid to laborers on federal road construction projects. For 1940-66, they use the average statelevel social security wage. The construction wages were only available by region, so they convert them to state-level indices by forming the average ratio of the state social security wage to the regional construction wage in the period 1940-44.

Pupil-teacher ratios were extracted on a biennial basis for the period 1916-1988 from two main data sources. Through 1968, pupil-teacher ratios were derived in general from Federal data reported in various issues of the Federal Biennial Survey of Education. State education reports (generally biennial) and other sources (mainly from the Nashville based Southern Reporting Service, an independent education monitoring organization) were used as needed to fill in the gaps. These additional sources were also used to check suspicious outliers generated from the Federal data. Post-1968, the pupil-teacher ratios were extracted from the National Center for Education Statistics, Historical Trends: State Education Facts (1992; diskette version supplied by the NCES). Exhaustive effort was made to maximize data consistency over time and/or across disparate sources.

State-level, aggregate pupil-teacher ratios were computed according to two definitions: (a) PTR-E, total teacher divided by total enrollment and (b) PTR-A, total teachers divided by average daily attendance. PRE-E used Card and Krueger's general

\footnotetext{
${ }^{1}$ Covering the 48 contiguous states and the District of Columbia.

${ }^{2}$ White term lengths were imputed for Southem states by taking the ratio of white term length to the aggregate for the nearest year and then applying that ratio to the aggregate term length in years when the white measure was missing.
} 
specification and substantially agrees with their results (there are occasional disparities due to reliance on different sources and/or different interpretations of data categories from the same source). PTR-A is used in this study to test the robustness of their results: we hypothesize that change in the quality of schooling inputs should have been more consequential for those pupils actually attending school than for those nominally enrolled but not attending. This is of particular concern for rural states and older cohorts.

To assess the effect of schooling quality on whites, racially specific pupil-teacher ratios and term length were computed to the extent that available sources permitted. Racially differentiated educational statistics are for practical purposes unavailable for the historically nonsegregated states. For these systems, aggregate pupil-teacher ratios were assembles. For the 18 historically segregated public education school systems ${ }^{3}$, data sources allowed compilation of white-specific measures covering much of the 1916-88 time period. Unfortunately, we were able to fund teacher salaries on an aggregate level only.

Virtually complete, white-specific PTR-E and PTR-A series were extracted from the Biennial Surveys, various Federal Office of Education studies appearing under such rubrics as Statistics of the Education of Negroes: A Decade of Progress (1943), and state education reports for the years 1916-1954. In the wake of the Brown vs. Board of Education decision that year, the Federal Government and many of the historically segregated states ceased publishing racially disaggregated educational statistics. However, the pace and timing of post-Brown school desegregation varies widely.

Where post-Brown legal desegregation ${ }^{4}$ was relatively immediate, as in the District of Columbia and a number of Boarder states, white-specific pupil-teacher ratios and white term lengths were immediately replaced by the non-differentiated, aggregate ratios used to characterize historically non-segregated systems. Where legal desegregation lagged, particularly in the Deep South, white-specific pupil-teacher ratios were extracted to the extent that available data (mainly from SERS publications and state reports) allowed. Since racially differentiated data in these instances typically because unavailable well before full desegregation had been effect, a smoothing procedure was employed to merge white-specific pupil-teacher ratios and the somewhat larger aggregate ratios.

Based on data appearing in the SERS gazette Southern School News, the increasing percentages of legally desegregated schools within individual states were calculated post-Brown through 1968 (when full legal desegregation was assumed). Partially segregated states were assigned an average of the last reported white-specific pupil-teacher ratio and the current aggregate ratio, weighted according to the current level of desegregation. ${ }^{5}$ Aggregate measures only were assigned once the legal desegregation in a given states schools reached a $95 \%$ threshold.

\footnotetext{
${ }^{3}$ These were: the states of Alabama, Arkansas, Delaware, Florida, Georgia, Kentucky, Louisiana, Maryland, Mississippi, Missouri, North Carolina, Oklahoma, South Carolina, Tennessee, Texas, Virginia, and West Virginia; and the District of Columbia.

${ }^{4}$ That is. certified complience with the then-prevailing interpretations of Federal law: nominal integration as far as the legal right to enroll, as distinguished from the de facto integration later sought by such court mandated measures as busing plans.

${ }^{5}$ That is. a state whose schools were $40 \%$ desegregated in a given year was assigned the pupil-teacher ratios equivalent to $60 \%$ of the last reported white-specific ratios and $40 \%$ of the relevant aggregate ratios and so on.
} 
Appendix C: Additional Tables 
Table 7b

1970 Census: The Effect of Schooling Quality on the Rate of Return to Education

Linear Model

Second Stage Model: Rate of Return $=\alpha+\alpha_{b}+\alpha_{r(s)}+\alpha_{c}+\alpha_{b c}+\alpha_{r i s k}$

(Eicker-White standard errors in parentheses)

\begin{tabular}{|c|c|c|c|c|c|c|c|c|c|c|}
\hline \multirow[b]{3}{*}{ Coefficient Estimates } & \multicolumn{10}{|c|}{ Second Stage Model Restrictions } \\
\hline & (1) & $(2)$ & (3) & \multicolumn{4}{|c|}{ (4) } & (5) & (6) & (7) \\
\hline & $\alpha_{b c}=\varphi Q_{b c}$ & $\alpha_{b c}=\varphi Q_{b c}$ & $\alpha_{b}+\alpha_{b c}$ & \multicolumn{4}{|c|}{$\alpha_{\mathrm{bc}}=\varphi_{\mathrm{c}} \mathrm{Q}_{\mathrm{bc}}$} & $\alpha_{r(s)}+\alpha_{T(s)}=$ & $\alpha_{\mathrm{r}(s)}+\alpha_{\mathrm{r}(\mathrm{sk})}=$ & $\alpha_{r(s)}+\alpha_{r(s)}=$ \\
\hline & & & & $10 \mathrm{~s}$ & $20 \mathrm{~s}$ & $30 \mathrm{~s}$ & $40 \mathrm{~s}$ & & & \\
\hline Pupil-Teacher Ratio & $\begin{array}{r}-8.10 \\
(1.48)\end{array}$ & $\begin{array}{l}-8.89 \\
(1.50)\end{array}$ & $\begin{array}{c}-2.14 \\
(0.70)\end{array}$ & $\begin{array}{l}-8.38 \\
(1.28)\end{array}$ & $\begin{array}{l}-1.79 \\
(1.21)\end{array}$ & $\begin{array}{c}4.66 \\
(0.89)\end{array}$ & $\begin{array}{c}0.36 \\
(1.77)\end{array}$ & $\begin{array}{r}-8.80 \\
(2.27)\end{array}$ & $\begin{array}{l}-8.79 \\
(2.24)\end{array}$ & $\begin{array}{l}-8.88 \\
(1.86)\end{array}$ \\
\hline Term Length & $\ldots$ & $\begin{array}{c}0.74 \\
(0.39)\end{array}$ & $\begin{array}{c}1.85 \\
(0.27)\end{array}$ & $\begin{array}{r}-0.16 \\
(0.32)\end{array}$ & $\begin{array}{r}4.59 \\
(0.37)\end{array}$ & $\begin{array}{r}3.45 \\
(0.55)\end{array}$ & $\begin{array}{l}7.08 \\
(1.35)\end{array}$ & $\begin{array}{c}0.80 \\
(0.67)\end{array}$ & $\begin{array}{l}1.09 \\
(0.67)\end{array}$ & $\begin{array}{c}0.89 \\
(0.53)\end{array}$ \\
\hline $\begin{array}{l}\text { Relative Teacher } \\
\text { Salary }\end{array}$ & $\ldots$ & $\begin{array}{c}1.20 \\
(0.31)\end{array}$ & $\begin{array}{c}0.33 \\
(0.09)\end{array}$ & $\begin{array}{c}0.97 \\
(0.19)\end{array}$ & $\begin{array}{c}0.07 \\
(0.12)\end{array}$ & $\begin{array}{r}0.39 \\
(0.15)\end{array}$ & $\begin{array}{l}-0.46 \\
(0.30)\end{array}$ & $\begin{array}{l}1.17 \\
(0.50)\end{array}$ & $\begin{array}{c}1.10 \\
(0.46)\end{array}$ & $\begin{array}{l}1.16 \\
(0.39)\end{array}$ \\
\hline $\begin{array}{l}\text { Demand and Supply } \\
\text { Aggregates }\end{array}$ & & & & & & & & & & \\
\hline reg. avg. P.T. Ratio & ... & $\cdots$ & $\cdots$ & $\cdots$ & ... & ... & $\cdots$ & $\begin{array}{l}19.19 \\
(1.87)\end{array}$ & $\begin{array}{l}14.40 \\
(1.91)\end{array}$ & $\begin{array}{l}-2.63 \\
(3.51)\end{array}$ \\
\hline reg. avg. Term Length & $\cdots$ & ... & ... & ... & ... & $\ldots$ & ... & $\ldots$ & $\begin{array}{c}-8.00 \\
(1.17)\end{array}$ & $\begin{array}{l}-4.21 \\
(2.15)\end{array}$ \\
\hline$\% 12$ years & $\ldots$ & ... & ... & ... & ... & ... & ... & ... & $\ldots$ & $\begin{array}{c}-0.12 \\
(0.02)\end{array}$ \\
\hline$\%$ 1-3 years college & $\ldots$ & $\ldots$ & ... & ... & ... & ... & ... & $\cdots$ & ... & $\begin{array}{c}-0.18 \\
(0.03)\end{array}$ \\
\hline$\% 4+$ college & ... & ... & ... & ... & $\cdots$ & ... & ... & $\cdots$ & $\cdots$ & $\begin{array}{c}0.09 \\
(0.04)\end{array}$ \\
\hline$\%$ manufacturing & $\ldots$ & ... & ... & .. & ... & ... & ... & ... & ... & $\begin{array}{l}-0.03 \\
(0.01)\end{array}$ \\
\hline
\end{tabular}

(1) The number of observations $=1764$ (49 states of birth $\times 9$ regions $\times 4$ cohorts).

(2) The $\%$ of the workforce in the manufacturing industry was computed from the 1970 Census using male and femake workers age 18 -65. The mean quality within a region of residence was caiculated using the 10-19, 20-29, 30-39 and 40-49 birth cohorts.

(3) The omitted education category is $<12$ years.

(4) The pupil-teacher ratio and term length were divided by 100 in the regression. The attendance based pupil-teacher ratio was used. 
Table 7c

1990 Census: The Effect of Schooling Quality on the Rate of Return to Education Linear Model

Second Stage Model: Rate of Return $=\alpha+\alpha_{b}+\alpha_{r(s)}+\alpha_{c}+\alpha_{b c}+\alpha_{r i s k}$

(Eicker-White standard errors in parentheses)

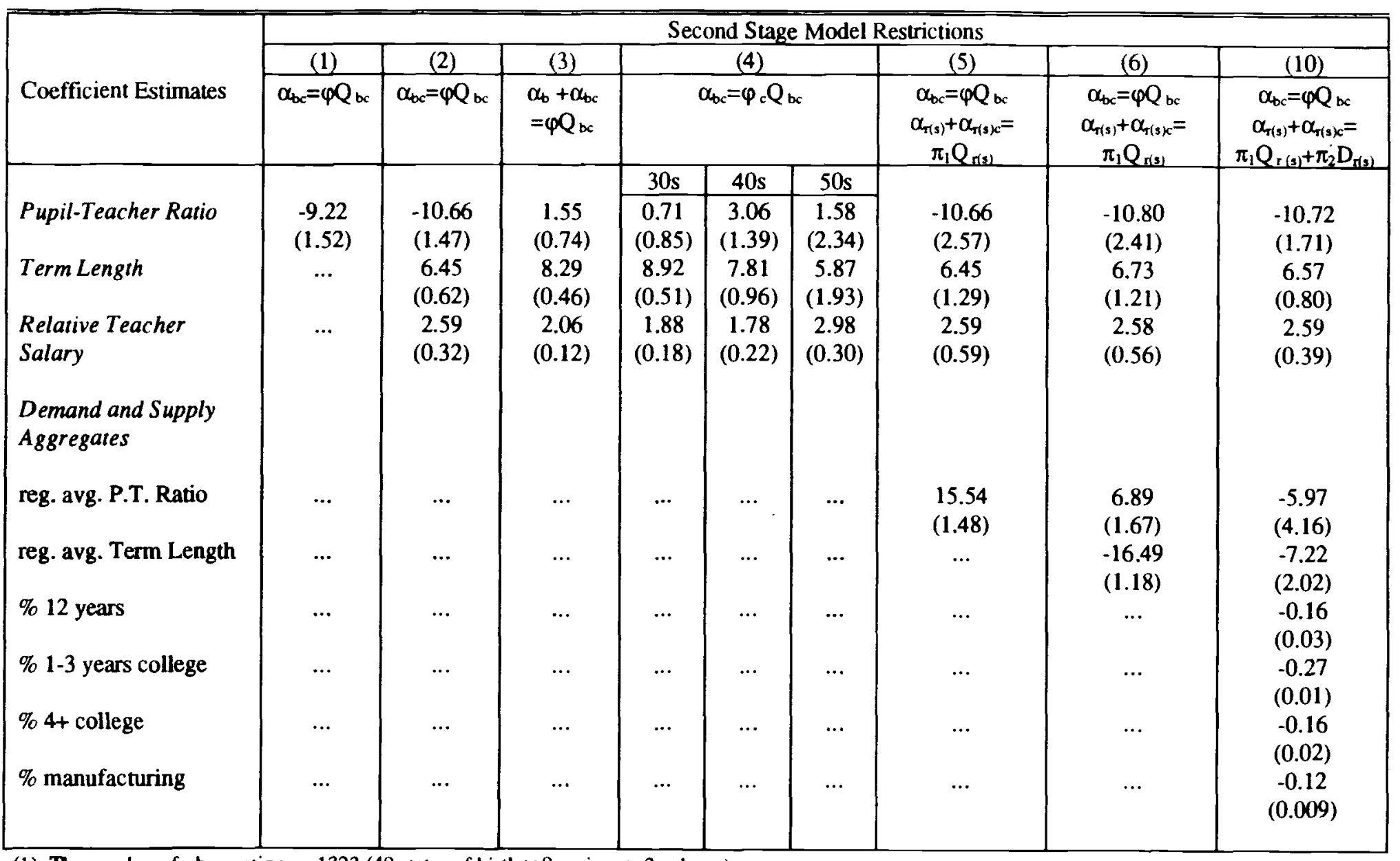

(1) The number of observations $=1323$ (49 states of birth $\times 9$ regions $\times 3$ cohorts).

(2) The \% of the workforce in the manufacturing industry was computed from the 1990 Census (Sample A) using male and female workers age $18-65$. The mean quality within a region of residence was calculated using the 30-39, 40-49, and 50-59 birth cohorts.

(3) The omitted education category is $<12$ years.

(4) The pupil-teacher ratio and term length were divided by 100 in the regression. The attendance based pupil-teacher ratio was used. 
Table 9b

1970 Census: The Effect of Schooling Quality on Fixed Effects

Linear Model

Second Stage Model: $\theta_{\mathrm{bsc}}=\theta+\theta_{\mathrm{b}}+\theta_{\mathrm{s}}+\theta_{\mathrm{c}}+\theta_{\mathrm{bc}}+\theta_{\mathrm{r}(3) \mathrm{c}}$

(Eicker-White standard errors in parentheses)

\begin{tabular}{|c|c|c|c|c|c|c|c|c|c|c|}
\hline & \multicolumn{10}{|c|}{ Model Specification } \\
\hline & (1) & (2) & (3) & \multicolumn{4}{|c|}{ (4) } & (5) & (6) & (7) \\
\hline \multirow[t]{2}{*}{ Coefficients: } & $\theta_{\mathrm{bc}}=\varphi \mathrm{Q}_{\mathrm{bc}}$ & $\theta_{\mathrm{bc}}=\varphi \mathrm{Q}$ & $\theta_{\mathrm{b}}+\theta_{\mathrm{bc}}$ & \multicolumn{4}{|c|}{$\theta_{b c}=\varphi_{c} Q_{b c}$} & $\theta_{\mathrm{bc}}=\varphi Q_{\mathrm{bc}}$ & $\theta_{\mathrm{bc}}=\varphi Q_{\mathrm{bc}}$ & $\theta_{\mathrm{bc}}=\varphi \mathrm{Q}_{\mathrm{bc}} \theta_{\mathrm{s}}+\theta_{\mathrm{sc}}=$ \\
\hline & & & & $10 \mathrm{~s}$ & $20 \mathrm{~s}$ & $30 \mathrm{~s}$ & $40 \mathrm{~s}$ & & & \\
\hline Pupil-Teacher & -1.43 & -1.32 & -0.39 & 0.25 & -0.41 & -1.07 & -0.35 & -1.71 & -1.71 & -1.71 \\
\hline Ratio & $(0.15)$ & $(0.15)$ & $(0.07)$ & $(0.13)$ & $(0.12)$ & $(0.10)$ & $(0.16)$ & $(0.15)$ & $(0.15)$ & $(0.15)$ \\
\hline Term Length & $\ldots$ & -0.39 & -0.16 & -0.05 & -0.30 & -0.09 & -0.01 & -0.46 & -0.46 & -0.46 \\
\hline 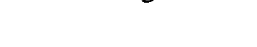 & & $(0.05)$ & $(0.03)$ & $(0.05)$ & $(0.05)$ & $(0.06)$ & $(0.12)$ & $(0.05)$ & $(0.05)$ & $(0.05)$ \\
\hline Relative Teacher & $\ldots$ & -0.07 & -0.01 & -0.08 & -0.01 & -0.01 & 0.08 & -0.05 & -0.05 & -0.05 \\
\hline Salary & & $(0.02)$ & $(0.01)$ & $(0.02)$ & $(0.01)$ & $(0.01)$ & $(0.02)$ & $(0.02)$ & $(0.02)$ & $(0.02)$ \\
\hline Demand and & & & & & & & & & & \\
\hline Supply & & & & & & & & & & \\
\hline Aggregates & & & & & & & & & & \\
\hline reg. avg. PTR-A & $\cdots$ & $\cdots$ & $\cdots$ & $\cdots$ & $\cdots$ & $\cdots$ & $\cdots$ & -0.98 & -0.95 & 7.04 \\
\hline & & & & & & & & $(0.45)$ & $(0.44)$ & $(0.82)$ \\
\hline reg. avg. Term & ... & $\cdots$ & ... & $\ldots$ & $\cdots$ & $\ldots$ & $\cdots$ & $\cdots$ & 1.78 & -0.78 \\
\hline Length & & & & & & & & & $(0.35)$ & (0.54) \\
\hline$\% 12$ years & .. & ... & .. & .. & $\cdots$ & $\cdots$ & .. & .. & ... & $\begin{array}{c}0.04 \\
(0.01)\end{array}$ \\
\hline $\begin{array}{l}\text { \% } 1.3 \text { years } \\
\text { college }\end{array}$ & ... & $\ldots$ & $\ldots$ & $\cdots$ & $\ldots$ & $\cdots$ & $\cdots$ & $\ldots$ & $\cdots$ & $\begin{array}{c}-0.01 \\
(0.01)\end{array}$ \\
\hline$\% 4+$ college & $\ldots$ & $\ldots$ & $\ldots$ & ... & $\ldots$ & $\ldots$ & ... & ... & $\ldots$ & $\begin{array}{c}0.05 \\
(0.01)\end{array}$ \\
\hline $\begin{array}{l}\% \\
\text { manufacturing }\end{array}$ & $\ldots$ & $\cdots$ & ... & $\cdots$ & $\cdots$ & $\cdots$ & $\cdots$ & $\cdots$ & $\cdots$ & $\begin{array}{c}0.01 \\
(0.001)\end{array}$ \\
\hline
\end{tabular}

(1) The number of observations $=9996$ (49 states of birth $\times 51$ states of residence $\times 4$ cohorts).

(2) The \% of the workforce in the manufacturing industry was computed from the 1970 Census using male and female workers age $18-65$.

The mean quality within a region of residence was calculated using the 10-19,20-29, 30-39, and 40-49 birth cohorts.

(3) The pupil-teacher ratio and term length were divided by 100 in the regression. The attendance based pupil-teacher ratio was used. 
Table 9c

1990 Census: The Effect of Schooling Quality on Fixed Effects

Linear Model

Second Stage Model: $\theta_{b 3 c}=\theta+\theta_{b}+\theta_{s}+\theta_{c}+\theta_{b c}+\theta_{r i s c}$

(Eicker-White standard errors in parentheses)

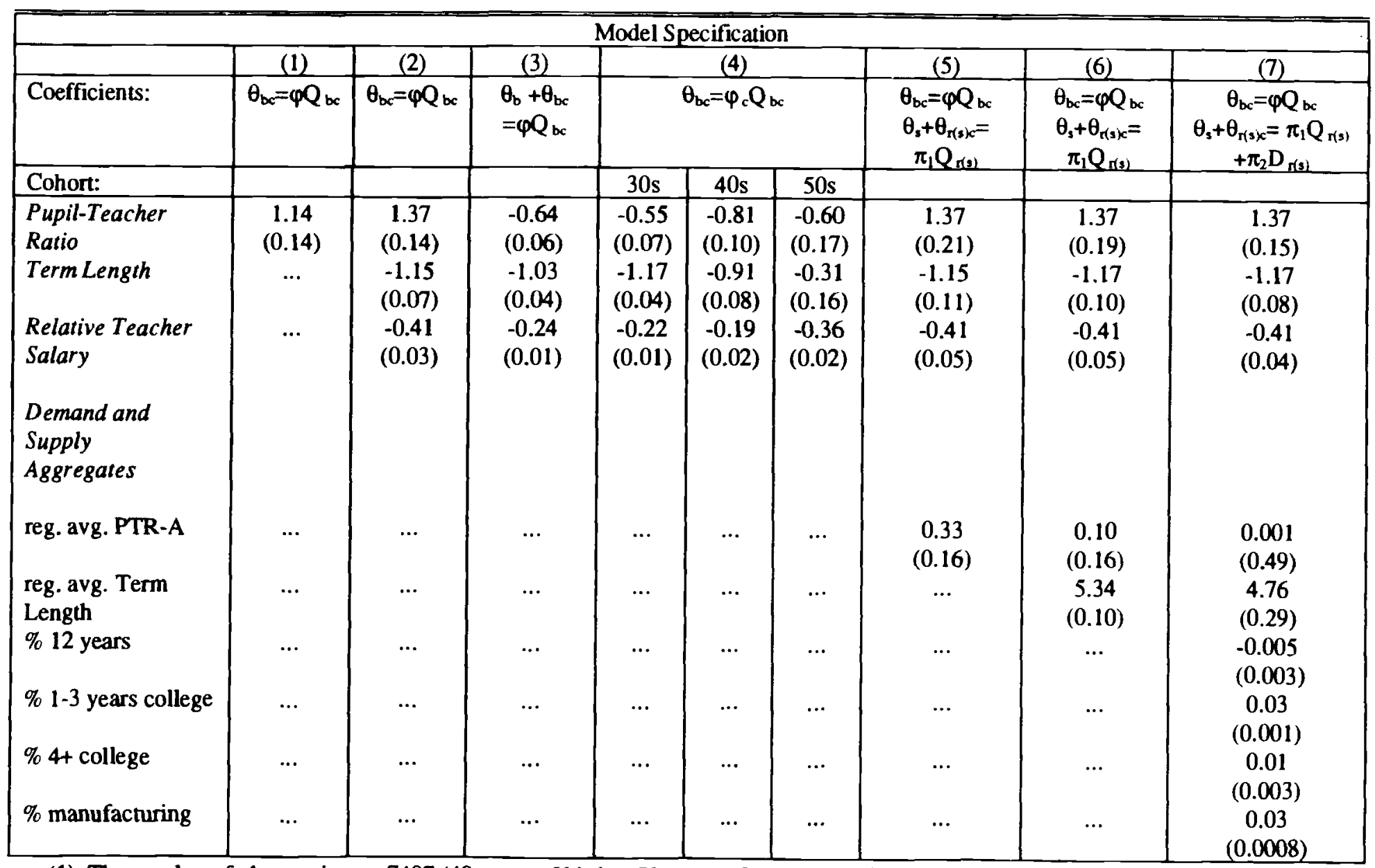

(1) The number of observations $=7497$ (49 states of birth $\times 51$ states of residence $\times 3$ ohorts).

(2) The \% of the workforce in the manufacturing industry was computed from the 199 J Census (A Sample) using male and female workers age 18-65. The mean quality within a region of residence was calculated using the 30-39, 40-49, and 50-59 birth cohorts.

(3) The pupil-teacher ratio and term length were divided by 100 in the regression. The attendarice based pupil-teacher ratio was used. 
Table 11.1(b)

1970 Census: The Effect of Schooling Quality on the Linear Base Return to Education Nonlinear Model

Second Stage Model: Rate of Return $=\alpha+\alpha_{b}+\alpha_{r(s)}+\alpha_{c}+\alpha_{b c}+\alpha_{r(s k c}$ (Eicker-White standard errors in parentheses)

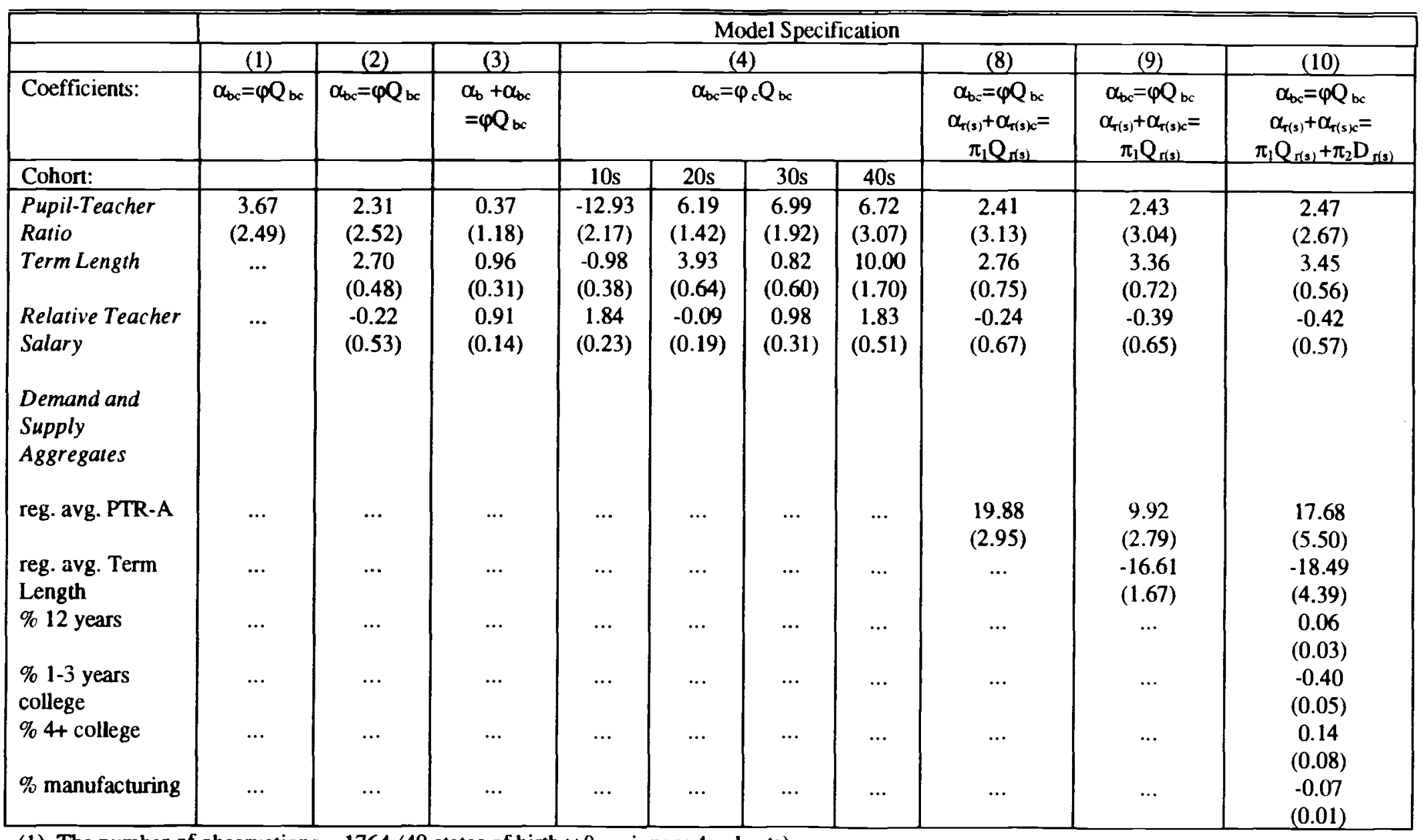

(1) The number of observations $=1764$ (49 states of birth $\times 9$ regions $\times 4$ cohorts).

(2) The $\%$ of the workforce in the manufacturing industry was computed from the 1970 Census using male and female workers age $18-65$. The mean quality within a region of residence was calculated using the 10-19,20-29, 30-39, and 40-49 birth cohorts.

(3) The pupil-teacher ratio and term length were divided by 100 in the regression. The attendance based pupil-teacher ratio was used. 
Table 11.2(b)

1970 Census: The Effect of Schooling Quality on the Marginal Rate of Return to 1-3 Years of College Nonlinear Model

Second Stage Model: Rate of Return $=\alpha+\alpha_{b}+\alpha_{T(s)}+\alpha_{c}+\alpha_{b c}+\alpha_{r(s k}$

(Eicker-White standard errors in parentheses)

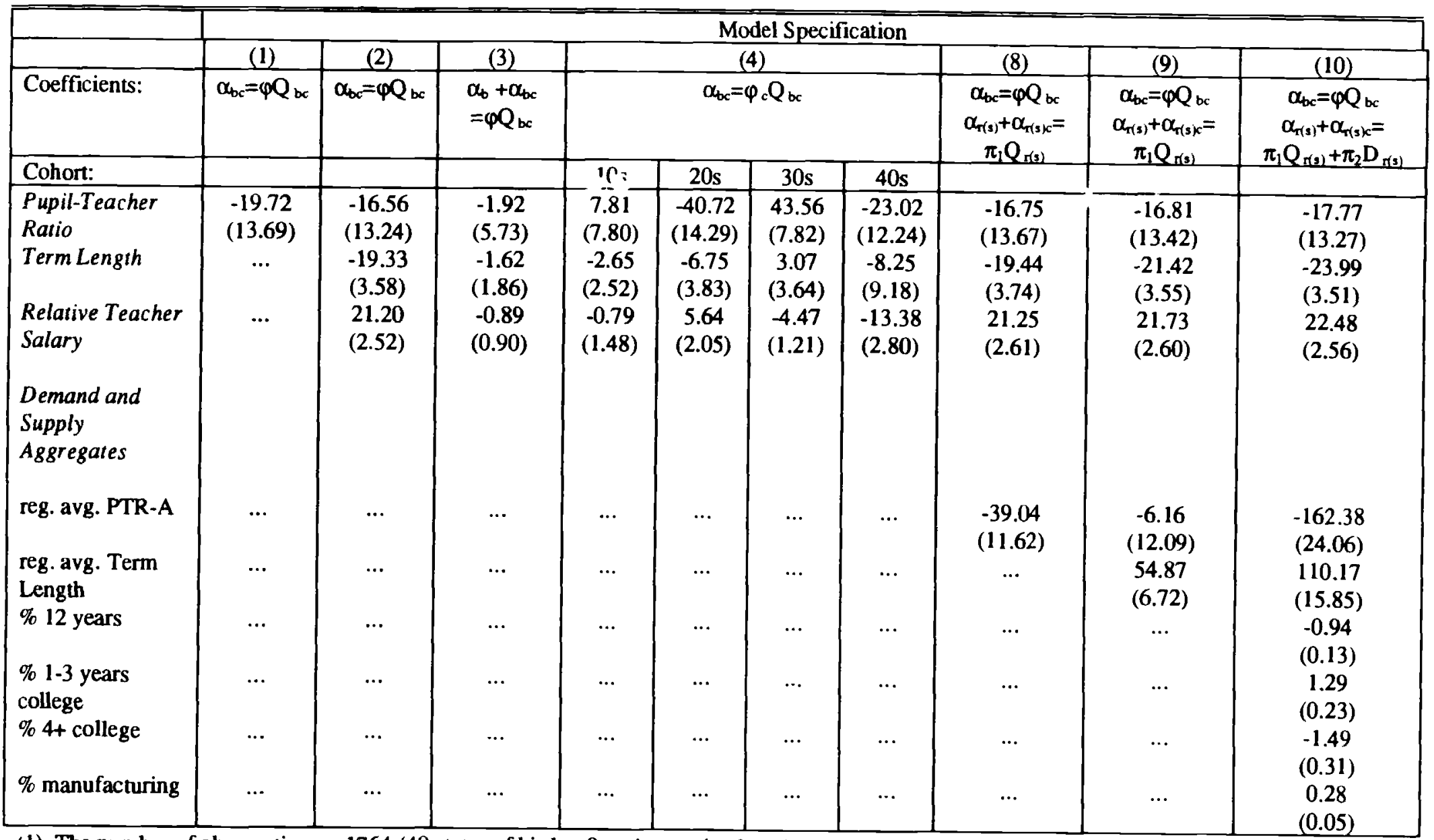

(1) The number of observations $=1764$ (49 states of birth $\times 9$ regions $\times 4$ cohorts).

(2) The $\%$ of the workforce in the manufacturing industry was computed from the 1970 Census using male and female workers age 18-65. The mean quality within a region of residence was calculated using the 10-19,20-29, 30-39, and 40-49 birth cohorts.

(3) The pupil-teacher ratio and term length were divided by 100 in the regression. The attendance based pupil-teacher ratio was used. 
Table 11.3(b)

1970 Census: The Effect of Schooling Quality on the Marginal Rate of Return to 4 Plus Years of College Nonlinear Model

Second Stage Model: Rate of Return $=\alpha+\alpha_{b}+\alpha_{r(s)}+\alpha_{c}+\alpha_{b c}+\alpha_{t(s)}$ (Eicker-White standard errors in parentheses)

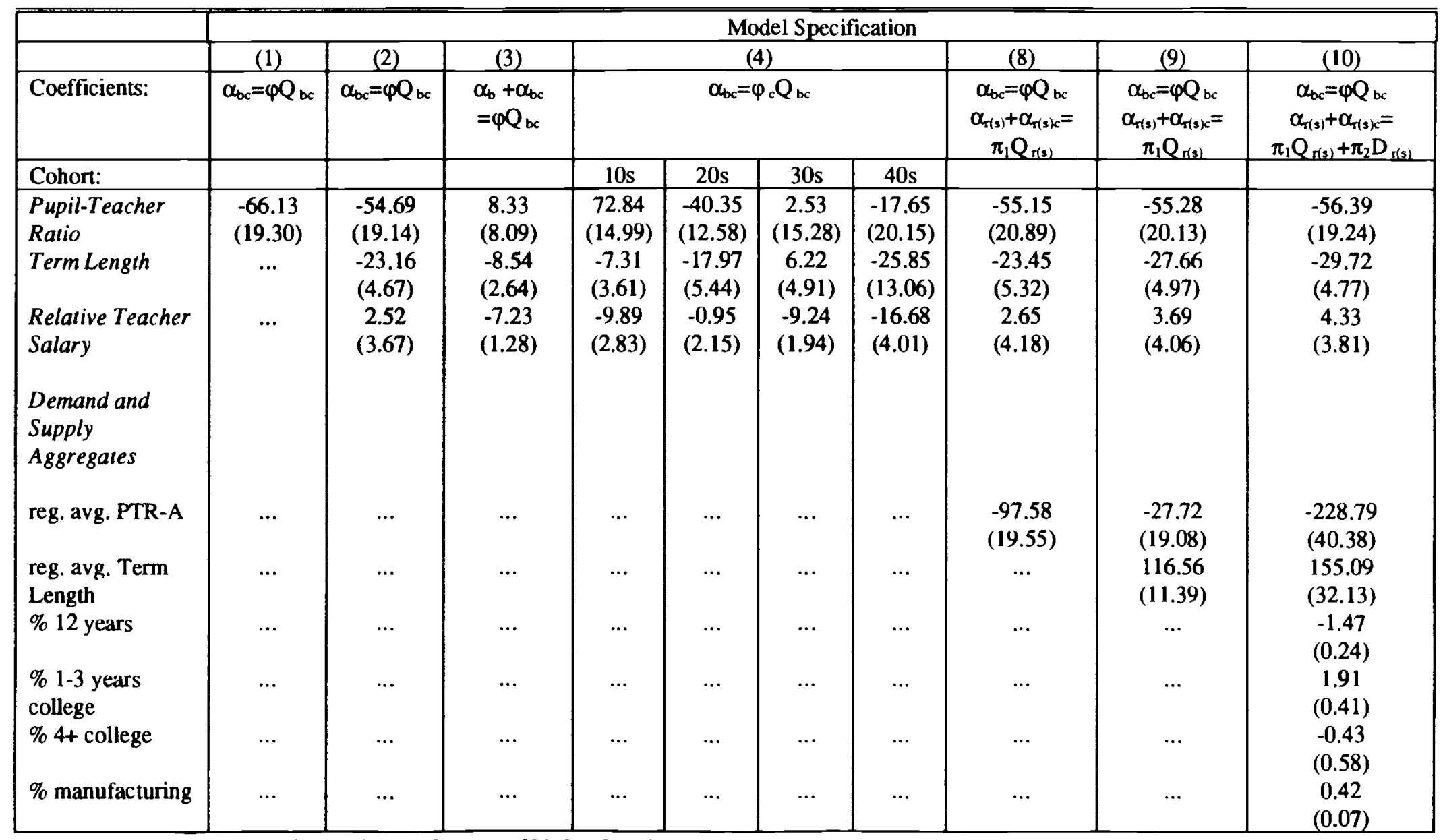

(1) The number of observations $=1764$ (49 states of birth $\times 9$ regions $\times 4$ cohorts).

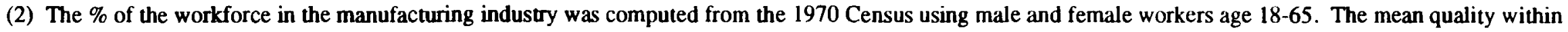
a region of residence was calculated using the 10-19,20-29, 30-39, and 40-49 birth cohorts.

(3) The pupil-teacher ratio and term length were divided by 100 in the regression. The altendance based pupil-teacher ratio was used. 
Table 11.1(c)

1990 Census: The Effect of Schooling Quality on the Linear Base Return to Education Nonlinear Model

Second Stage Model: Rate of Return $=\alpha+\alpha_{b}+\alpha_{r(s)}+\alpha_{c}+\alpha_{b c}+\alpha_{r(s, k}$ (Eicker-White standard errors in parentheses)

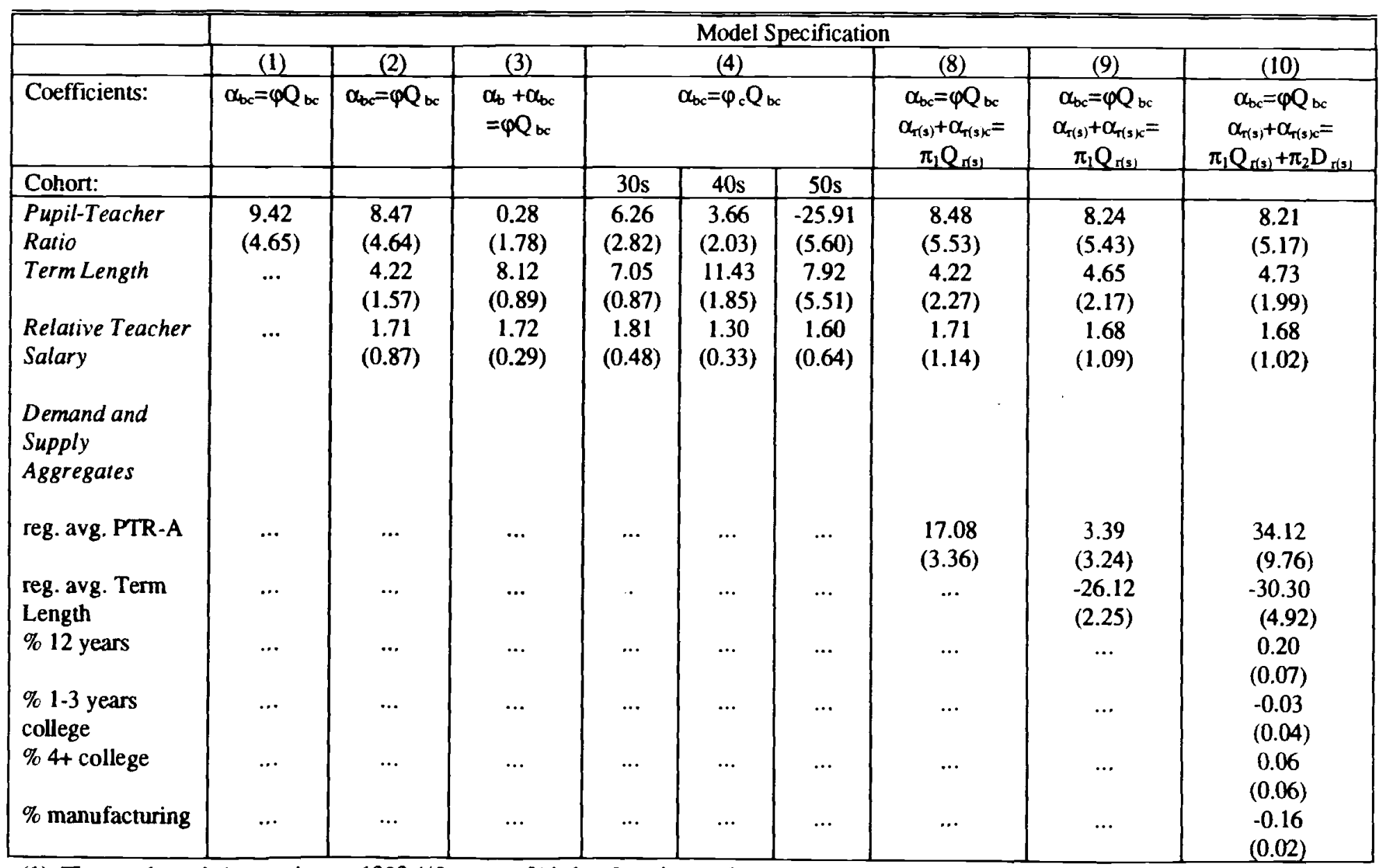

(1) The number of observations $=1323$ (49 states of birth $\times 9$ regions $\times 3$ cohorts).

(2) The $\%$ of the workforce in the manufacturing industry was computed from the 1990 Census (A Sample) using male and female workers age 18-65. The mean quality within a region of residence was calculated using the 30-39, 40-49, and 50-59 birth cohorts.

(3) The pupil-teacher ratio and term length were divided by 100 in the regression. The attendance based pupil-teacher ratio was used. 
Table 11.2(c)

1990 Census: The Effect of Schooling Quality on the Marginal Rate of Return to 1-3 Years of College Nonlinear Model

Second Stage Model: Rate of Return $=\alpha+\alpha_{b}+\alpha_{T(s)}+\alpha_{c}+\alpha_{b c}+\alpha_{T(s)}$ (Eicker-White standard errors in parentheses)

\begin{tabular}{|c|c|c|c|c|c|c|c|c|c|}
\hline & \multicolumn{9}{|c|}{ Model Specification } \\
\hline & (1) & (2) & (3) & \multicolumn{3}{|c|}{ (4) } & $(8)$ & (9) & (10) \\
\hline Coefficients: & $\alpha_{b c}=\varphi Q_{b c}$ & $\alpha_{b c}=\varphi Q_{b c}$ & $\begin{array}{l}\alpha_{b}+\alpha_{b c} \\
=\varphi Q_{b c}\end{array}$ & \multicolumn{3}{|c|}{$\alpha_{b c}=\varphi_{c} Q_{b c}$} & $\begin{array}{c}\alpha_{b c}=\varphi Q_{b c} \\
\alpha_{r(s)}+\alpha_{r(s) c}= \\
\pi_{1} Q_{r(s)}\end{array}$ & $\begin{array}{c}\alpha_{b c}=\varphi Q_{b c} \\
\alpha_{r(s)}+\alpha_{r(s) c}= \\
\pi_{1} Q_{r(s)}\end{array}$ & $\begin{array}{c}\alpha_{b c}=\varphi Q_{b c} \\
\alpha_{r(s)}+\alpha_{r(s)}= \\
\pi_{1} Q_{(s)}+\pi_{2} D_{r(s)}\end{array}$ \\
\hline Cohort: & & & & $30 \mathrm{~s}$ & $40 \mathrm{~s}$ & $50 \mathrm{~s}$ & & & \\
\hline $\begin{array}{l}\text { Pupil-Teacher } \\
\text { Ratio } \\
\end{array}$ & $\begin{array}{c}1.76 \\
(15.39)\end{array}$ & $\begin{array}{c}-1.60 \\
(15.46)\end{array}$ & $\begin{array}{l}52.23 \\
(5.40)\end{array}$ & $\begin{array}{l}24.95 \\
(7.92)\end{array}$ & $\begin{array}{l}57.06 \\
(5.55)\end{array}$ & $\begin{array}{l}125.94 \\
(15.62)\end{array}$ & $\begin{array}{c}-1.61 \\
(17.31)\end{array}$ & $\begin{array}{c}-1.14 \\
(17.05)\end{array}$ & $\begin{array}{c}-0.86 \\
(16.67)\end{array}$ \\
\hline Term Length & .. & $\begin{array}{c}0.92 \\
(5.72)\end{array}$ & $\begin{array}{r}-12.31 \\
(3.86)\end{array}$ & $\begin{array}{l}-7.60 \\
(4.22)\end{array}$ & $\begin{array}{l}-14.18 \\
(6.59)\end{array}$ & $\begin{array}{l}-53.85 \\
(19.68)\end{array}$ & $\begin{array}{c}0.92 \\
(7.18)\end{array}$ & $\begin{array}{c}0.04 \\
(6.97)\end{array}$ & $\begin{array}{l}-0.53 \\
(6.69)\end{array}$ \\
\hline $\begin{array}{l}\text { Relative Teacher } \\
\text { Salary }\end{array}$ & $\cdots$ & $\begin{array}{c}6.78 \\
(2.85)\end{array}$ & $\begin{array}{c}1.60 \\
(0.99)\end{array}$ & $\begin{array}{c}0.95 \\
(1.60)\end{array}$ & $\begin{array}{c}4.39 \\
(1.34)\end{array}$ & $\begin{array}{c}0.58 \\
(2.17)\end{array}$ & $\begin{array}{c}6.78 \\
(3.44)\end{array}$ & $\begin{array}{l}6.83 \\
(3.34)\end{array}$ & $\begin{array}{l}6.85 \\
(3.22)\end{array}$ \\
\hline $\begin{array}{l}\text { Demand and } \\
\text { Supply } \\
\text { Aggregates }\end{array}$ & & & & & & & & & \\
\hline reg. avg. PTR-A & $\cdots$ & $\ldots$ & $\cdots$ & $\cdots$ & $\cdots$ & $\cdots$ & $\begin{array}{l}-41.25 \\
(10.10)\end{array}$ & $\begin{array}{l}-13.68 \\
(10.34)\end{array}$ & $\begin{array}{r}-169.15 \\
(34.30)\end{array}$ \\
\hline $\begin{array}{l}\text { reg. avg. Term } \\
\text { Length }\end{array}$ & $\cdots$ & ... & $\cdots$ & $\cdots$ & $\ldots$ & $\cdots$ & $\ldots$ & $\begin{array}{l}52.59 \\
(7.57)\end{array}$ & $\begin{array}{c}85.82 \\
(16.12)\end{array}$ \\
\hline$\% 12$ years & $\cdots$ & $\ldots$ & $\cdots$ & $\cdots$ & $\cdots$ & $\cdots$ & ... & $\cdots$ & $\begin{array}{l}-1.13 \\
(0.23)\end{array}$ \\
\hline $\begin{array}{l}\% 1-3 \text { years } \\
\text { college }\end{array}$ & $\cdots$ & $\cdots$ & ... & ... & $\cdots$ & $\cdots$ & $\ldots$ & $\cdots$ & $\begin{array}{l}-1.20 \\
(0.12)\end{array}$ \\
\hline$\% 4+$ college & $\cdots$ & $\cdots$ & $\cdots$ & ... & $\cdots$ & $\cdots$ & $\ldots$ & $\cdots$ & $\begin{array}{l}-0.80 \\
(0.20)\end{array}$ \\
\hline$\%$ manufacturing & ... & $\cdots$ & $\cdots$ & $\cdots$ & $\cdots$ & $\cdots$ & $\cdots$ & $\cdots$ & $\begin{array}{c}0.24 \\
(0.07) \\
\end{array}$ \\
\hline
\end{tabular}

(1) The number of observations $=1323$ (49 states of birth $\times 9$ regions $\times 3$ cohorts).

(2) The \% of the workforce in the manufacturing industry was computed from the 1990 Census (A Sample) using male and female workers age 18-65. The mean quality within a region of residence was calculated using the 30-39, 40-49, and 50-59 birth cohorts.

(3) The pupil-teacher ratio and term length were divided by 100 in the regression. The attendance based pupil-teacher ratio was used. 
Table 11.3(c)

1990 Census: The Effect of Schooling Quality on the Marginal Rate of Return to 4 or More Years of College

Nonlinear Model

Second Stage Model: Rate of Return $=\alpha+\alpha_{b}+\alpha_{r(s)}+\alpha_{c}+\alpha_{b c}+\alpha_{r(s k}$

(Eicker-White standard errors in parentheses)

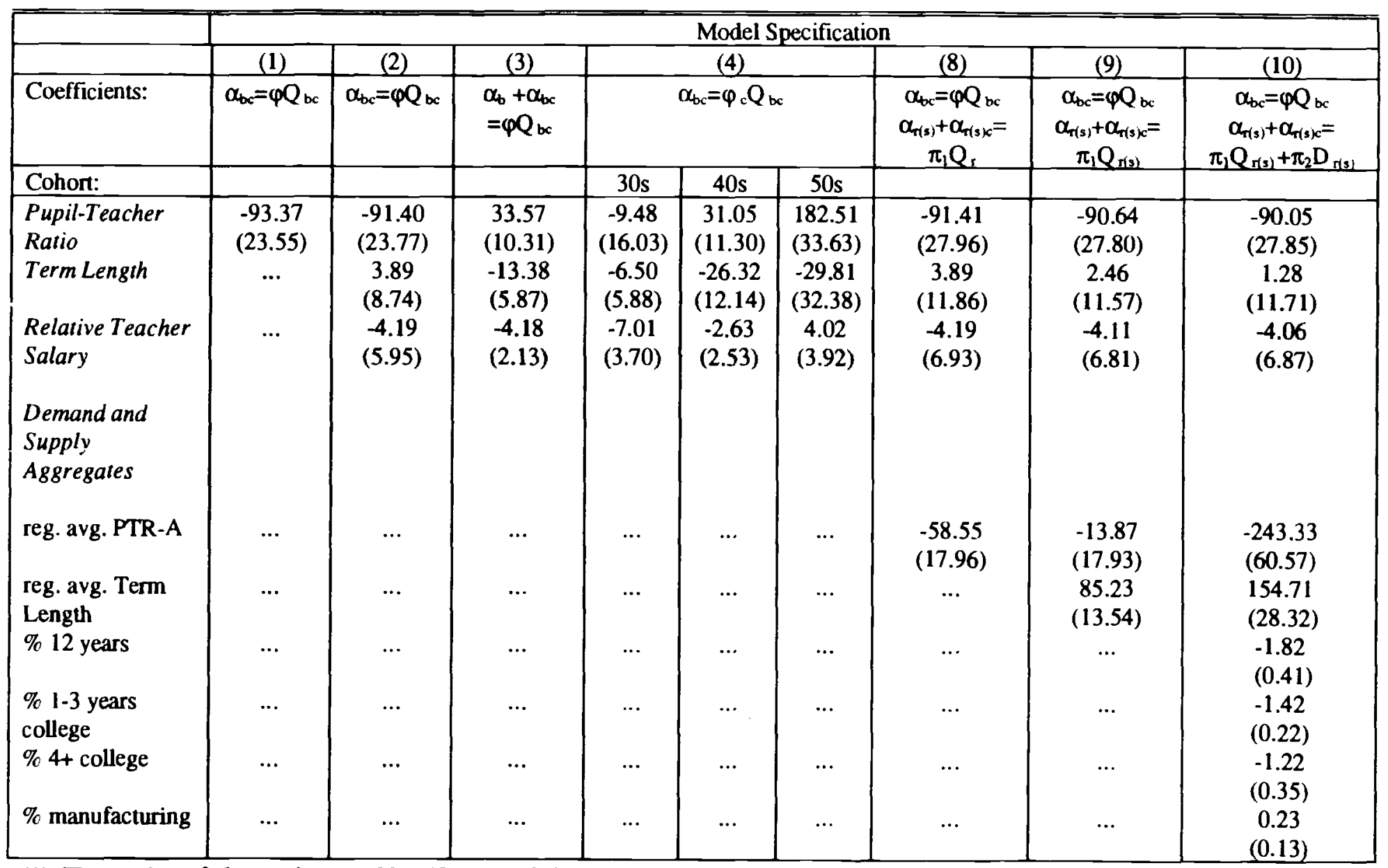

(1) The number of observations $=1323$ (49 states of birth $\times 9$ regions $\times 3$ cohorts)

(2) The \% of the workforce in the manufacturing industry was computed from the 1990 Census (A Sample) using male and female workers age 18-65. The mean quality within a region of residence was calculated using the 30-39, 40-49, and 50-59 birth cohorts.

(3) The pupil-teacher ratio and term length were divided by 100 in the regression. The attendance based pupil-teacher ratio was used. 
Table $14 c$ continued

1990 Census: The Effect of Schooling Quality on the Return to Education Linear Model with Region of Birth*Region of Residence Interactions

Second Stage Model: Rate of Return $=\alpha+\alpha_{b}+\alpha_{r(s)}+\alpha_{c}+\alpha_{b c}+\alpha_{r(s) c}+\alpha_{r(s) r(b)}+\alpha_{r(s) r(b) c}$ (Eicher-White standard errors in parentheses)

\begin{tabular}{|c|c|c|c|c|c|}
\hline \multirow[b]{3}{*}{ Coefficient Estimates } & \multicolumn{5}{|c|}{ Second Stage Model Restrictions } \\
\hline & (1) & (2) & (3) & (4) & (5) \\
\hline & \multicolumn{4}{|c|}{$\alpha_{b c}+\alpha_{r(b) r(s)}+\alpha_{r(b) r(s) c}=\phi_{r(s)} Q_{b c}+\eta d$} & $\alpha_{b}+\alpha_{b c}+\alpha_{r(b) r(s)}+\alpha_{r(b) r(s) c}=\phi_{r(s)} Q_{b c}+\eta d$ \\
\hline Term Lengih & & & & & \\
\hline New Englind & $\ldots$ & $\ldots$ & $\begin{array}{c}-1.58 \\
(3.38)\end{array}$ & $\begin{array}{c}-3.19 \\
(3.53)\end{array}$ & $\begin{array}{c}16.09 \\
(3.89)\end{array}$ \\
\hline Middle Atlantic & $\ldots$ & $\cdots$ & $\begin{array}{c}-5.49 \\
(4.27)\end{array}$ & $\begin{array}{c}-7.73 \\
(4.40)\end{array}$ & $\begin{array}{c}10.80 \\
(5.10)\end{array}$ \\
\hline East North Central & ... & ... & $\begin{array}{c}-3.26 \\
(2.86)\end{array}$ & $\begin{array}{c}-5.12 \\
(2.85)\end{array}$ & $\begin{array}{l}13.60 \\
(4.28)\end{array}$ \\
\hline West North Central & $\ldots$ & $\ldots$ & $\begin{array}{c}-6.43 \\
(4.35)\end{array}$ & $\begin{array}{c}-7.50 \\
(4.49)\end{array}$ & $\begin{array}{l}11.50 \\
(4.91)\end{array}$ \\
\hline South Atlantic & $\ldots$ & $\ldots$ & $\begin{array}{c}-5.81 \\
(3.67)\end{array}$ & $\begin{array}{c}-9.67 \\
(3.51)\end{array}$ & $\begin{array}{c}9.46 \\
(4.92)\end{array}$ \\
\hline Eist South Central & ... & ... & $\begin{array}{c}-14.47 \\
(3.57)\end{array}$ & $\begin{array}{c}-16.21 \\
(3.64)\end{array}$ & $\begin{array}{c}2.80 \\
(3.91)\end{array}$ \\
\hline West South Central & $\ldots$ & $\ldots$ & $\begin{array}{c}-12.30 \\
(3.38)\end{array}$ & $\begin{array}{c}-13.10 \\
(3.49)\end{array}$ & $\begin{array}{c}5.68 \\
(3.61)\end{array}$ \\
\hline Mountain & $\cdots$ & $\cdots$ & $\begin{array}{c}5.63 \\
(4.17)\end{array}$ & $\begin{array}{c}6.38 \\
(4.14)\end{array}$ & $\begin{array}{l}23.34 \\
(5.11)\end{array}$ \\
\hline Pacific & ... & ... & $\begin{array}{c}-2.79 \\
(2.38)\end{array}$ & $\begin{array}{c}-3.14 \\
(2.36)\end{array}$ & $\begin{array}{l}11.95 \\
(3.81)\end{array}$ \\
\hline distance & $\begin{array}{c}2.09 \\
(0.26)\end{array}$ & $\begin{array}{c}2.27 \\
(0.25)\end{array}$ & $\begin{array}{c}2.44 \\
(0.25)\end{array}$ & $\begin{array}{c}2.26 \\
(0.25)\end{array}$ & $\begin{array}{c}1.65 \\
(0.32)\end{array}$ \\
\hline distance squared & $\begin{array}{c}-0.52 \\
(0.08) \\
\end{array}$ & $\begin{array}{c}-0.57 \\
(0.08) \\
\end{array}$ & $\begin{array}{c}-0.63 \\
(0.08) \\
\end{array}$ & $\begin{array}{c}-0.58 \\
(0.08) \\
\end{array}$ & $\begin{array}{c}-0.20 \\
(0.10) \\
\end{array}$ \\
\hline
\end{tabular}

(1) The number of observations $=1343$ (49 states of birth $\times 9$ regions $\times 3$ cohorts).

121 The \% of the workforce in the manufacturing industry was computed from the 1990 Census using male and female wurkers age $18-65$. The mean quality within a region of residence was calculated using the 30-39, 40-49, and 50-59 cohorts.

13) The comutted eduction category is $<12$ years.

14) The pupi-teacher ratio and term length were divided by 100 in the regression. The attendance based pupil-teacher ra to was used.

(5) Distance is measured in thousands of miles. 
Table 14c

1990 Census: The Effect of Schooling Quality on the Return to Education Linear Model with Region of Birth*Region of Residence Interactions

Second Stage Model: Rate of Return $=\alpha+\alpha_{b}+\alpha_{r(s)}+\alpha_{c}+\alpha_{b c}+\alpha_{r(s) c}+\alpha_{r(s) r(b)}+\alpha_{r(s) r(b) c}$ (Eicher-White standard errors in parentheses)

\begin{tabular}{|c|c|c|c|c|c|}
\hline \multirow[b]{3}{*}{ Coefficient Estimates } & \multicolumn{5}{|c|}{ Second Stage Model Restrictions } \\
\hline & (1) & (2) & (3) & (4) & (5) \\
\hline & \multicolumn{4}{|c|}{$\alpha_{b c}+\alpha_{r(b) r(s)}+\alpha_{r(b) r(s) c}=\phi_{r(s)} Q_{b c}+\eta d$} & $\alpha_{b}+\alpha_{b c}+\alpha_{r(b) r(s)}+\alpha_{r(b) r(s) c}=\phi_{r(s)} Q_{b c}+\eta d$ \\
\hline \multicolumn{6}{|l|}{ Pupil-Teacher Ratio } \\
\hline New England & $\begin{array}{l}-26.44 \\
(6.90)\end{array}$ & $\cdots$ & $\ldots$ & $\begin{array}{c}-27.57 \\
(6.83)\end{array}$ & $\begin{array}{c}-13.52 \\
(6.47)\end{array}$ \\
\hline Middle Atlantic & $\begin{array}{r}-29.07 \\
(8.39)\end{array}$ & $\ldots$ & $\ldots$ & $\begin{array}{c}-31.22 \\
(8.41)\end{array}$ & $\begin{array}{c}-17.47 \\
(7.79)\end{array}$ \\
\hline East North Central & $\begin{array}{c}-30.47 \\
(6.11)\end{array}$ & $\ldots$ & $\ldots$ & $\begin{array}{c}-32.10 \\
(6.01)\end{array}$ & $\begin{array}{c}-18.22 \\
(5.62)\end{array}$ \\
\hline West North Central & $\begin{array}{c}-24.09 \\
(7.20)\end{array}$ & $\ldots$ & $\ldots$ & $\begin{array}{c}-26.84 \\
(7.12)\end{array}$ & $\begin{array}{c}-11.55 \\
(6.62)\end{array}$ \\
\hline South Atlantic & $\begin{array}{c}-46.50 \\
(5.77)\end{array}$ & $\ldots$ & $\ldots$ & $\begin{array}{c}-48.90 \\
(5.78)\end{array}$ & $\begin{array}{c}-34.72 \\
(6.04)\end{array}$ \\
\hline East South Central & $\begin{array}{c}-28.10 \\
(6.38)\end{array}$ & ... & $\ldots$ & $\begin{array}{c}-32.07 \\
(6.18)\end{array}$ & $\begin{array}{r}-18.09 \\
(5.15)\end{array}$ \\
\hline West South Central & $\begin{array}{c}-22.50 \\
(5.75)\end{array}$ & ... & $\ldots$ & $\begin{array}{c}-25.95 \\
(5.61)\end{array}$ & $\begin{array}{c}-11.35 \\
(4.56)\end{array}$ \\
\hline Mountain & $\begin{array}{c}-14.85 \\
(8.22)\end{array}$ & $\ldots$ & $\ldots$ & $\begin{array}{c}-14.01 \\
(8.07)\end{array}$ & $\begin{array}{c}-0.24 \\
(7.99)\end{array}$ \\
\hline Pacific & $\begin{array}{c}-17.53 \\
(5.23)\end{array}$ & $\ldots$ & $\ldots$ & $\begin{array}{c}-18.57 \\
(5.18)\end{array}$ & $\begin{array}{l}-6.90 \\
(5.36)\end{array}$ \\
\hline \multicolumn{6}{|l|}{ Teucher Salary } \\
\hline New England & $\ldots$ & $\begin{array}{c}2.97 \\
(1.50)\end{array}$ & $\ldots$ & $\begin{array}{c}4.08 \\
(1.54)\end{array}$ & $\begin{array}{c}1.65 \\
(1.05)\end{array}$ \\
\hline Middle Atlantic & $\ldots$ & $\begin{array}{c}3.19 \\
(1.52)\end{array}$ & $\cdots$ & $\begin{array}{c}4.50 \\
(1.53)\end{array}$ & $\begin{array}{c}2.10 \\
(1.28)\end{array}$ \\
\hline East North Central & $\ldots$ & $\begin{array}{c}2.97 \\
(1.32)\end{array}$ & $\ldots$ & $\begin{array}{c}4.21 \\
(1.32)\end{array}$ & $\begin{array}{c}1.79 \\
(1.14)\end{array}$ \\
\hline West North Central & ... & $\begin{array}{c}3.12 \\
(1.65)\end{array}$ & $\ldots$ & $\begin{array}{c}4.35 \\
(1.66)\end{array}$ & $\begin{array}{c}1.90 \\
(1.26)\end{array}$ \\
\hline South Atlantic & $\ldots$ & $\begin{array}{c}3.00 \\
(1.31)\end{array}$ & $\ldots$ & $\begin{array}{c}4.63 \\
(1.31)\end{array}$ & $\begin{array}{c}2.19 \\
(1.25)\end{array}$ \\
\hline East South Central & $\ldots$ & $\begin{array}{c}3.07 \\
(1.48)\end{array}$ & $\ldots$ & $\begin{array}{c}4.65 \\
(1.43)\end{array}$ & $\begin{array}{c}2.21 \\
(0.93)\end{array}$ \\
\hline West South Central & ... & $\begin{array}{c}3.11 \\
(1.49)\end{array}$ & $\ldots$ & $\begin{array}{c}4.51 \\
(1.45)\end{array}$ & $\begin{array}{c}2.07 \\
(0.88)\end{array}$ \\
\hline Mountain & ... & $\begin{array}{c}2.99 \\
(1.53)\end{array}$ & $\ldots$ & $\begin{array}{c}3.61 \\
(1.53)\end{array}$ & $\begin{array}{c}1.24 \\
(1.39)\end{array}$ \\
\hline Pacific & $\ldots$ & $\begin{array}{c}3.23 \\
(1.14)\end{array}$ & $\ldots$ & $\begin{array}{c}4.21 \\
(1.16)\end{array}$ & $\begin{array}{c}1.92 \\
(0.81)\end{array}$ \\
\hline
\end{tabular}


Table 14b continued

1970 Census: The Effect of Schooling Quality on the Return to Education Linear Model with Region of Birth*Region of Residence Interactions

Second Stage Model: Rate of Return $=\alpha+\alpha_{b}+\alpha_{r(s)}+\alpha_{c}+\alpha_{b c}+\alpha_{r(s) c}+\alpha_{r(s) r(b)}+\alpha_{r(s) r(b) c}$ (Eicher-White standard errors in parentheses)

\begin{tabular}{|c|c|c|c|c|c|}
\hline \multirow[b]{3}{*}{ Coefficient Estimates } & \multicolumn{5}{|c|}{ Second Stage Model Restrictions } \\
\hline & (1) & (2) & (3) & (4) & (5) \\
\hline & \multicolumn{4}{|c|}{$\alpha_{b c}+\alpha_{r(b) r(s)}+\alpha_{r(b) r(s) c}=\phi_{r(s)} Q_{b c}+\eta d$} & $\alpha_{b}+\alpha_{b c}+\alpha_{r(b) r(s)}+\alpha_{r(b) r(s) c}=\phi_{r(s)} Q_{b c}+\eta d$ \\
\hline \multicolumn{6}{|l|}{ Term Length } \\
\hline New England & $\ldots$ & $\ldots$ & $\begin{array}{c}2.36 \\
(2.16)\end{array}$ & $\begin{array}{c}3.04 \\
(2.45)\end{array}$ & $\begin{array}{c}4.22 \\
(2.44)\end{array}$ \\
\hline Middle Atlantic & $\ldots$ & $\ldots$ & $\begin{array}{c}0.09 \\
(1.17)\end{array}$ & $\begin{array}{c}-0.36 \\
(1.34)\end{array}$ & $\begin{array}{c}0.88 \\
(1.34)\end{array}$ \\
\hline East North Central & $\ldots$ & $\ldots$ & $\begin{array}{c}3.61 \\
(1.18)\end{array}$ & $\begin{array}{c}3.47 \\
(1.31)\end{array}$ & $\begin{array}{c}4.96 \\
(1.23)\end{array}$ \\
\hline West North Central & $\ldots$ & $\ldots$ & $\begin{array}{c}-2.97 \\
(1.79)\end{array}$ & $\begin{array}{c}-3.47 \\
(1.84)\end{array}$ & $\begin{array}{c}-1.82 \\
(1.72)\end{array}$ \\
\hline South Atlantic & $\ldots$ & ... & $\begin{array}{c}1.79 \\
(1.12)\end{array}$ & $\begin{array}{c}1.18 \\
(1.22)\end{array}$ & $\begin{array}{c}2.82 \\
(0.98)\end{array}$ \\
\hline East South Central & ... & $\ldots$ & $\begin{array}{c}2.44 \\
(1.82)\end{array}$ & $\begin{array}{c}3.21 \\
(2.00)\end{array}$ & $\begin{array}{c}4.97 \\
(1.85)\end{array}$ \\
\hline West South Central & $\ldots$ & $\ldots$ & $\begin{array}{c}-1.32 \\
(1.26)\end{array}$ & $\begin{array}{l}-2.05 \\
(1.48)\end{array}$ & $\begin{array}{c}-0.18 \\
(1.28)\end{array}$ \\
\hline Mountain & $\ldots$ & $\ldots$ & $\begin{array}{c}2.59 \\
(1.32)\end{array}$ & $\begin{array}{c}2.63 \\
(1.51)\end{array}$ & $\begin{array}{c}4.25 \\
(1.44)\end{array}$ \\
\hline Pacific & ... & $\ldots$ & $\begin{array}{c}1.96 \\
(1.01)\end{array}$ & $\begin{array}{c}1.61 \\
(1.11)\end{array}$ & $\begin{array}{c}3.03 \\
(0.99)\end{array}$ \\
\hline distance & $\begin{array}{c}1.17 \\
(0.24)\end{array}$ & $\begin{array}{c}1.28 \\
(0.23)\end{array}$ & $\begin{array}{c}1.35 \\
(0.23)\end{array}$ & $\begin{array}{c}1.28 \\
(0.25)\end{array}$ & $\begin{array}{c}1.04 \\
(0.25)\end{array}$ \\
\hline distance squared & $\begin{array}{c}-0.22 \\
(0.09)\end{array}$ & $\begin{array}{c}-0.26 \\
(0.09)\end{array}$ & $\begin{array}{c}-0.28 \\
(0.09)\end{array}$ & $\begin{array}{c}-0.25 \\
(0.09)\end{array}$ & $\begin{array}{c}-0.19 \\
(0.10)\end{array}$ \\
\hline
\end{tabular}

(1) The number of observations $=1764$ (49 states of birth $\times 9$ regions $\times 3$ cohorts).

(2) The \% of the workforce in the manufacturing industry was computod from the 1970 Census using male and female workers age 18-65. The mean quality within a region of residence was calculated using the 10-19,20-29, 30-39, and 40-49 cohors.

(3) The omitted eduction category is $<12$ years.

(4) The pupil-teacher ratio and term length were divided by 100 in the regression. The attendance based pupil-teacher ratio was used.

(5) Distance is measured in thousands of miles. 
Table 14b

1970 Census: The Effect of Schcoling Quality on the Return to Education Linear Model with Region of Birth*Region of Residence Interactions

Second Stage Model: Rate of Return $=\alpha+\alpha_{b}+\alpha_{r(s)}+\alpha_{c}+\alpha_{b c}+\alpha_{r(s) c}+\alpha_{r(s) r(b)}+\alpha_{r(s) r(b) c}$ (Eicher-White standard errors in parentheses)

\begin{tabular}{|c|c|c|c|c|c|}
\hline \multirow[b]{3}{*}{ Eoefficient Estimates } & \multicolumn{5}{|c|}{ Second Stage Model Restrictions } \\
\hline & (1) & (2) & (3) & (4) & (5) \\
\hline & \multicolumn{4}{|c|}{$\alpha_{b c}+\alpha_{r(b) r(s)}+\alpha_{r(b) r(s) c}=\phi_{r(s)} Q_{b c}+\eta d$} & $\alpha_{b}+\alpha_{b c}+\alpha_{r(b) r(s)}+\alpha_{r(b) r(s) c}=\phi_{r(s)} Q_{b c}+\eta d$ \\
\hline \multicolumn{6}{|l|}{ Pupil-Teacher Ratio } \\
\hline New England & $\begin{array}{c}2.67 \\
(5.05)\end{array}$ & $\ldots$ & $\cdots$ & $\begin{array}{c}2.68 \\
(5.11)\end{array}$ & $\begin{array}{l}12.24 \\
(4.76)\end{array}$ \\
\hline Middle Atlantic & $\begin{array}{l}-8.55 \\
(3.72)\end{array}$ & $\ldots$ & $\cdots$ & $\begin{array}{c}-9.71 \\
(3.74)\end{array}$ & $\begin{array}{c}-0.36 \\
(2.76)\end{array}$ \\
\hline East North Central & $\begin{array}{l}-12.15 \\
(3.48)\end{array}$ & $\ldots$ & $\ldots$ & $\begin{array}{l}-12.33 \\
(3.55)\end{array}$ & $\begin{array}{l}-2.52 \\
(2.56)\end{array}$ \\
\hline West North Central & $\begin{array}{l}-3.27 \\
(4.00)\end{array}$ & $\cdots$ & $\cdots$ & $\begin{array}{c}-5.81 \\
(4.00)\end{array}$ & $\begin{array}{c}5.01 \\
(2.93)\end{array}$ \\
\hline South Atlantic & $\begin{array}{l}-16.57 \\
(3.61)\end{array}$ & $\ldots$ & $\cdots$ & $\begin{array}{l}-17.32 \\
(3.64)\end{array}$ & $\begin{array}{c}-7.97 \\
(2.37)\end{array}$ \\
\hline East South Central & $\begin{array}{c}2.77 \\
(4.90)\end{array}$ & $\cdots$ & $\ldots$ & $\begin{array}{c}2.83 \\
(4.97)\end{array}$ & $\begin{array}{l}12.59 \\
(4.12)\end{array}$ \\
\hline West South Central & $\begin{array}{l}-11.58 \\
(3.89)\end{array}$ & $\ldots$ & $\ldots$ & $\begin{array}{l}-13.47 \\
(3.87)\end{array}$ & $\begin{array}{l}-3.39 \\
(2.72)\end{array}$ \\
\hline Mountain & $\begin{array}{l}-7.14 \\
(3.99)\end{array}$ & $\cdots$ & $\ldots$ & $\begin{array}{l}-7.69 \\
(4.06)\end{array}$ & $\begin{array}{c}2.86 \\
(2.90)\end{array}$ \\
\hline Pacific & $\begin{array}{c}-11.26 \\
(3.52) \\
\end{array}$ & $\cdots$ & $\ldots$ & $\begin{array}{c}-11.89 \\
(3.66) \\
\end{array}$ & $\begin{array}{l}-1.96 \\
(2.45) \\
\end{array}$ \\
\hline \multicolumn{6}{|l|}{ Teacher Salary } \\
\hline New England & $\ldots$ & $\begin{array}{c}1.03 \\
(0.78)\end{array}$ & $\ldots$ & $\begin{array}{c}0.40 \\
(0.85)\end{array}$ & $\begin{array}{l}-0.44 \\
(0.64)\end{array}$ \\
\hline Middle Atlantic & $\ldots$ & $\begin{array}{c}1.07 \\
(0.56)\end{array}$ & $\ldots$ & $\begin{array}{c}1.12 \\
(0.64)\end{array}$ & $\begin{array}{c}0.28 \\
(0.40)\end{array}$ \\
\hline East North Central & $\ldots$ & $\begin{array}{c}1.07 \\
(0.55)\end{array}$ & $\ldots$ & $\begin{array}{c}0.72 \\
(0.60)\end{array}$ & $\begin{array}{c}-0.17 \\
(0.38)\end{array}$ \\
\hline West North Central & $\ldots$ & $\begin{array}{c}1.10 \\
(0.74)\end{array}$ & $\ldots$ & $\begin{array}{c}1.43 \\
(0.76)\end{array}$ & $\begin{array}{c}0.50 \\
(0.57)\end{array}$ \\
\hline South Atlantic & $\ldots$ & $\begin{array}{c}1.03 \\
(0.60)\end{array}$ & $\ldots$ & $\begin{array}{c}1.06 \\
(0.66)\end{array}$ & $\begin{array}{c}0.17 \\
(0.37)\end{array}$ \\
\hline East South Central & $\ldots$ & $\begin{array}{l}1.08 \\
(0.75)\end{array}$ & $\ldots$ & $\begin{array}{c}0.42 \\
(0.80)\end{array}$ & $\begin{array}{c}-0.49 \\
(0.64)\end{array}$ \\
\hline West South Central & $\cdots$ & $\begin{array}{c}1.05 \\
(0.72)\end{array}$ & $\ldots$ & $\begin{array}{c}1.38 \\
(0.80)\end{array}$ & $\begin{array}{c}0.45 \\
(0.52)\end{array}$ \\
\hline Mountain & $\ldots$ & $\begin{array}{c}1.06 \\
(0.69)\end{array}$ & $\ldots$ & $\begin{array}{c}0.70 \\
(0.75)\end{array}$ & $\begin{array}{l}-0.21 \\
(0.58)\end{array}$ \\
\hline Pacific & $\ldots$ & $\begin{array}{c}1.04 \\
(0.58) \\
\end{array}$ & $\ldots$ & $\begin{array}{c}0.90 \\
(0.63) \\
\end{array}$ & $\begin{array}{c}0.02 \\
(0.36)\end{array}$ \\
\hline
\end{tabular}

